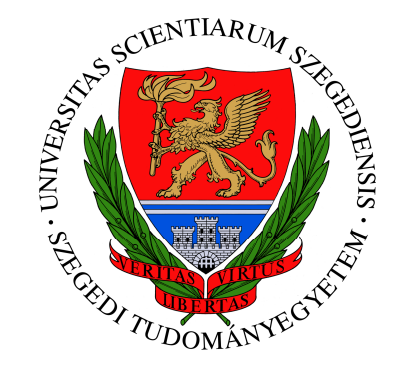

Szegedi Tudományegyetem

Biológia Doktori Iskola

Természettudományi

és Informatikai Kar

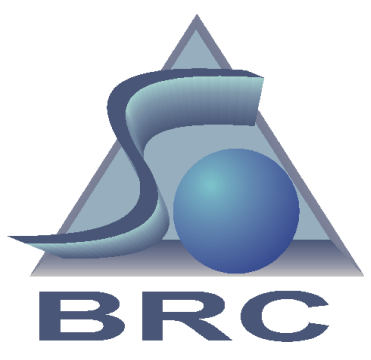

MTA Szegedi Biológiai Központ Genetikai Intézet

\title{
TÁRSBÉRLŐ GUBACSDARAZSAK FILOGENETIKÁJA ÉS FILOGEOGRÁFIÁJA
}

Ph.D. értekezés

\section{Bihari Péter}

Témavezető:

\section{Dr. Pénzes Zsolt,}

egyetemi docens,

SZTE TTIK, Ökológiai Tanszék, tudományos munkatárs,

MTA SZBK, Genetikai Intézet 


\section{Tartalomjegyzék}

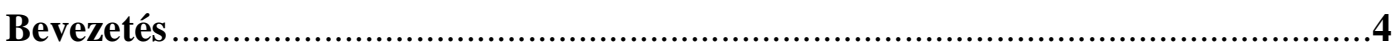

Gubacsok és gubacsdarazsak (Cynipidae) ..........................................................

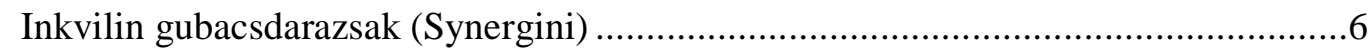

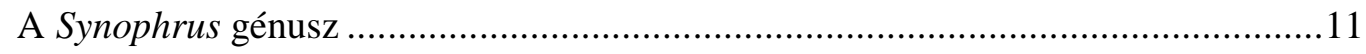

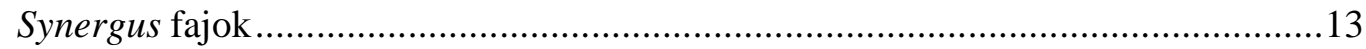

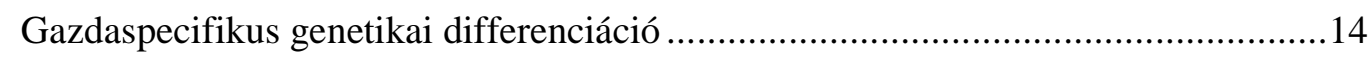

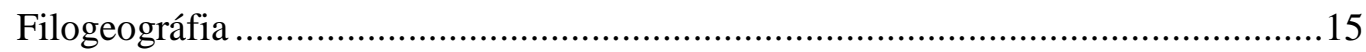

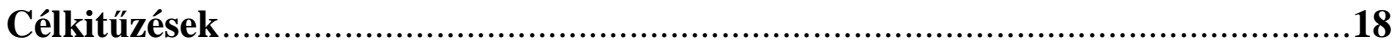

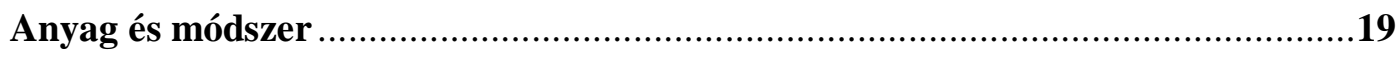

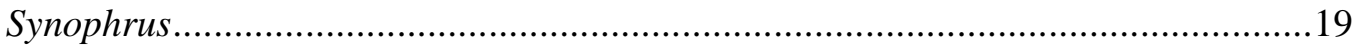

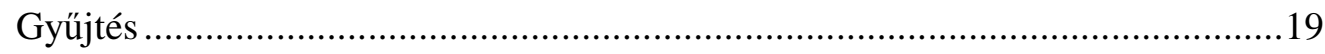

DNS izolálás, amplifikálás, szekvenálás és a szekvenciák összeállítása................21

A szekvenciák elemzése .............................................................................22

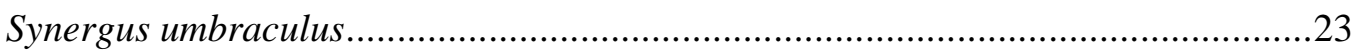

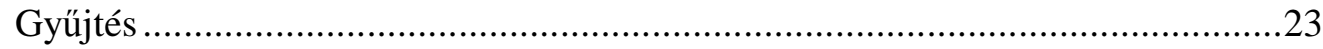

DNS izolálás, amplifikálás, szekvenálás és a szekvenciák illesztése....................24

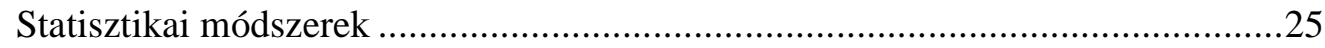

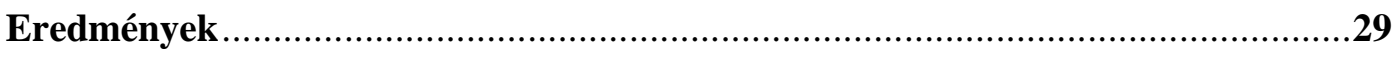

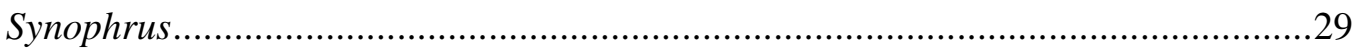

Molekuláris filogenetika és diverzitás .....................................................29

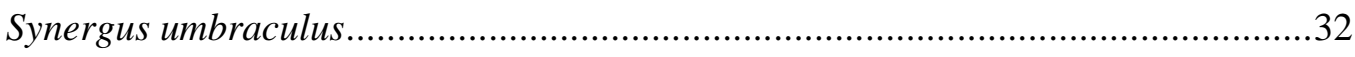

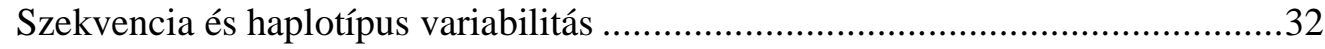

Filogenetikai elemzés és a haplocsoportok jellemzése.....................................36

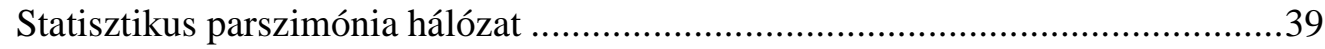

Genetikai differenciáció.......................................................................41

Gazda szerinti genetikai differenciáció......................................................42

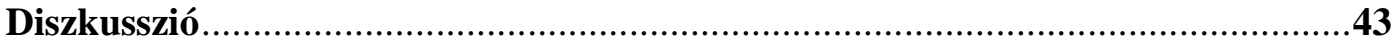


Synophrus.

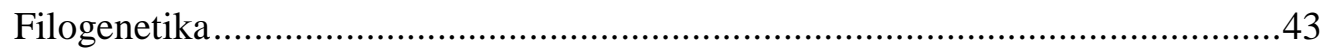

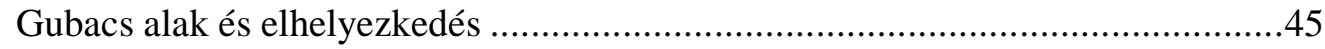

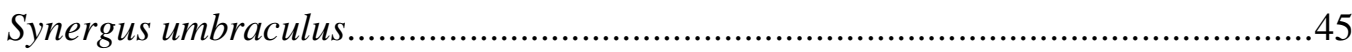

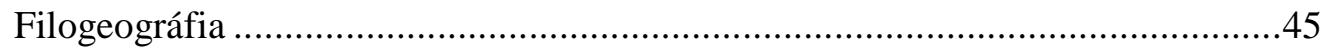

A genetikai diverzitásbeli mintázatok hasonlósága a gubacs közösség tagjai

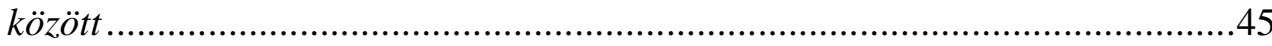

A Kárpát-medence genetikai diverzitása ...................................................47

Az észak-európai Synergus umbraculus populáció eredete .............................48

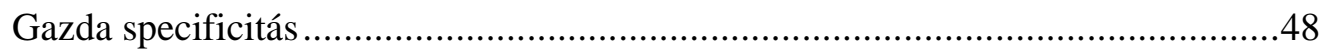

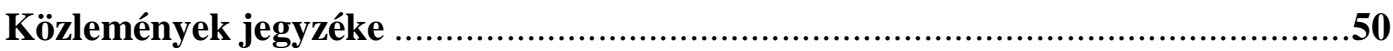

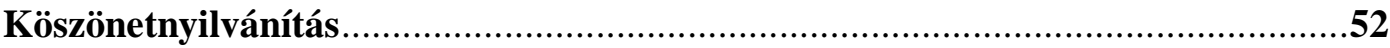

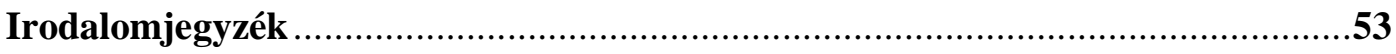

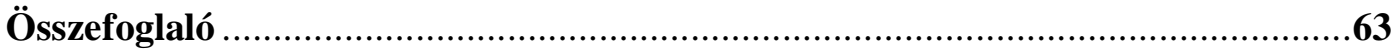

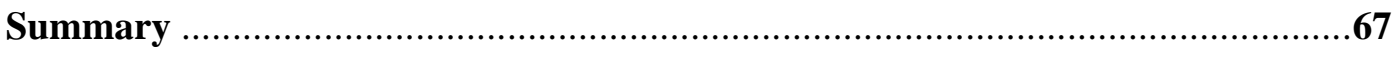

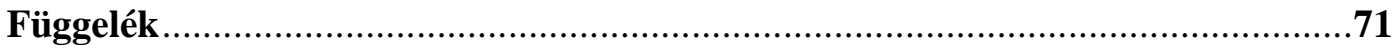




\section{Bevezetés}

\section{Gubacsok és gubacsdarazsak (Cynipidae)}

A gubacs növényi szövetek rendellenes differenciációja, melyet valamilyen élő szervezet aktivitása okoz. A rovarok körében a gubacsindukálás képessége többször kialakult az evolúció során, eddig hozzávetőleg 13000 gubacsképző rovarfajt írtak le (Dreger-Jauffret és Shorthouse, 1992). Köztük a gubacsdarazsak (Hymenoptera: Cynipidae) az egyik legnépesebb csoport, körülbelül 1400 fajuk ismert, rendkívül változatos gubacsfelépítéssel és gazdanövény kapcsolatokkal jellemezhetőek (Ronquist és Liljeblad, 2001; Stone és Schönrogge, 2003; Melika, 2006).

A Cynipidae család különleges helyet foglal el egy 75\%-ban parazitoidokat magában foglaló családsorozatban, mivel tagjai valamennyien növényevők. A Cynipidae család fajainak többsége tölgyfajokon (Quercus) képez gubacsot, ezeket nevezzük összefoglalóan tölgygubacsdarazsaknak (Cynipini). A fitofág rovarok között a tölgygubacsdarazsak rendkívül konzervatívnak tekinthetők a növényi gazda specificitás szempontjából (Stone és mtsi, 2009). A gubacsdarázs és a gazdanövénye közti kölcsönhatás szoros, általában specifikus a gazda fajcsoportra és a szervre egyaránt. A Cynipini fajok által indukált gubacs formája általában fajspecifikus a gubacsképzőre, emiatt egyes esetekben a darázs könnyen meghatározható a gubacs alapján (Melika, 2006). Mindez azt jelenti, hogy a gubacs jellegzetességei (formája, szerkezete, felszíni képződményei) a cyinipid darázs kiterjesztett fenotípusának tekinthetőek (Stone és Schönrogge, 2003). A rovarokra, így a gubacsdarazsakra jellemző gubacsindukció mechanizmusa pillanatnyilag ismeretlen (Stone és Schönrogge, 2003), az azonban bizonyos, hogy a gubacsdarázs lárva képes ezt a folyamatot kontrollálni, és a növényt arra kényszeríteni, hogy számára lárvakamrát és endospermium szerü táplálószövetet hozzon létre, amelyben, illetve amelyből táplálkozhat fejlődése során.

A Cynipini fajok további sajátsága az összetett, ciklikusan szüznemző életciklus: tavasszal ivaros generációjuk, nyár végén illetve ősszel ivartalan, partenogenetikus generációjuk fejlődik. A két nemzedék egyedei és az általuk képzett gubacsok morfológiája, illetve növényi gazdáik is jelentősen eltérhetnek egymástól. Manos és mtsi (1999) molekuláris filogenetika alapján a Quercus subgenus-t a következő 4 
szekcióra osztották: Cerris, Lobatae, Quercus sensu stricto és Protobalanus. A Nyugat Palearktikumban csak a Cerris és a Quercus sensu stricto szekcióba sorolható fajok élnek. A tölgygubacsdarazsak között számos Andricus faj és Callirhytis fajok obligát módon váltogatják gazdájukat. Az Andricus fajok nagy részének ivaros generációja a Cerris szekció valamely faján (pl. Quercus cerris - csertölgy) fejlődik, az ivartalan generáció pedig a Quercus sensu stricto szekció valamely faján fejlődik (pl. Quercus robur - kocsányos tölgy, Quercus petraea - kocsánytalan tölgy, Quercus pubescens molyhos tölgy). Callirhytis fajok esetén mindez fordítva történik. A két tölgyszekció elterjedése ilyen módon meghatározza ezen fajok elterjedését a Nyugat Palearktikumban (1. ábra). A csertölgy természetes elterjedési területe humán behatásra az elmúlt 500 évben jelentősen kibővült: észak felé Dániáig és Skóciáig, nyugat felé Franciaország atlanti partjáig.

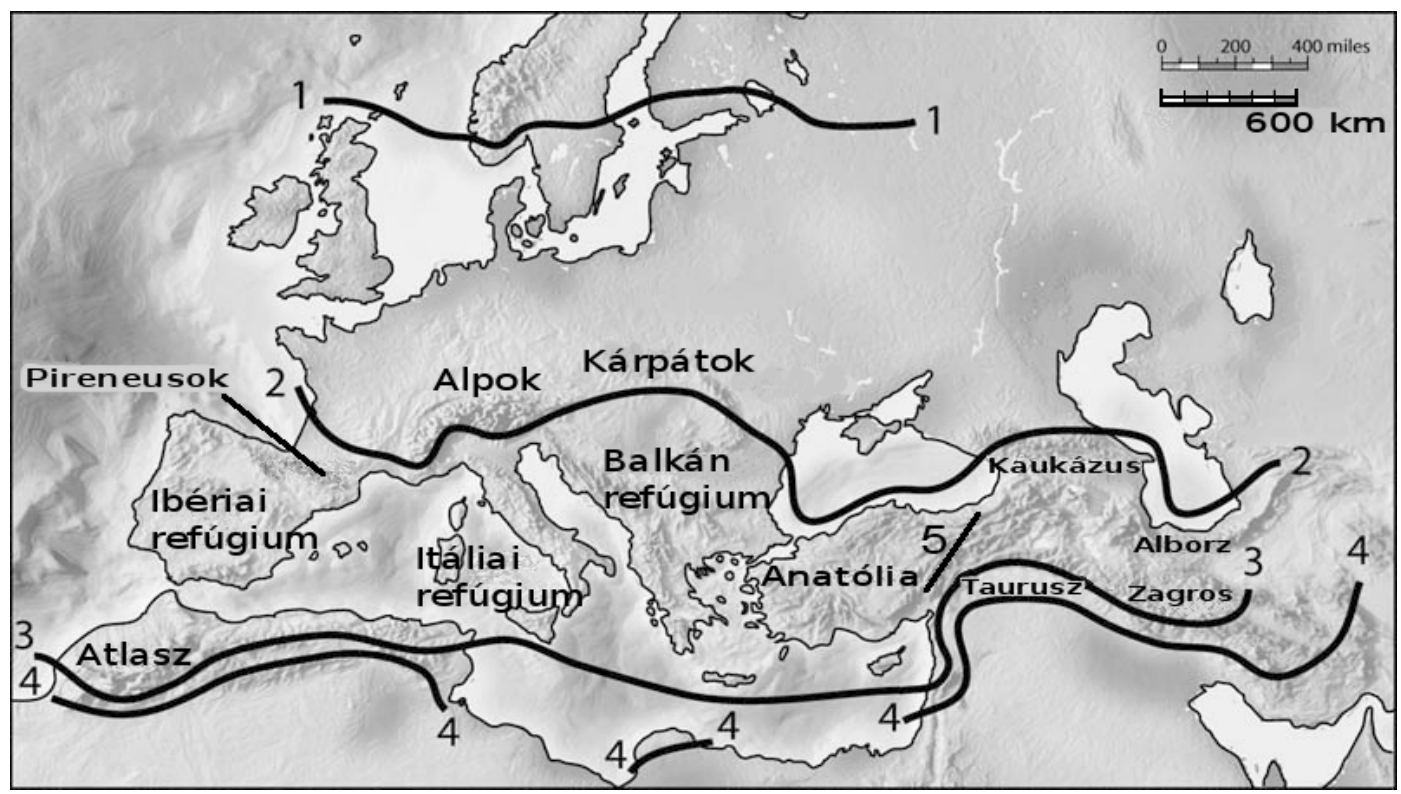

1. ábra A Quercus subgenus szekcióinak természetes elterjedési területe a Nyugat Palearktikumban. A subgenus Quercus sensu stricto szekciójának elterjedési területe az 1. és 3. vonalak közé esik. A Cerris szekció elterjedésének határait a 2. és 4. vonalak jelölik. Csak a 2. és 3. vonalak közé eső területen található meg mindkét szekció együtt. Az 5. vonal az Anatóliai Diagonál hozzávetőleges helyét mutatja. Stone és mtsi (2007) nyomán, módosítva.

A gubacsok egy jellegzetes, zárt és fajgazdag közösségnek adnak otthont, melyben a gubacsképző lárváján kívül parazitoid darazsak (Bailey és mtsi, 2009) és 
növényevő társbérlők (inkvilinek) is fejlődhetnek (2. ábra). Ez utóbbiak szintén a gubacs szöveteit fogyasztják, de önmaguk képtelenek a gubacsindukcióra (Ronquist, 1994; Ács és mtsi, 2010). A tölgygubacs közösségek számos ökológiai és evolúciós vizsgálat modellrendszerei (Hayward és Stone, 2005; Bailey és mtsi, 2009; Stone és mtsi, 2009). Az inkvilinek gyakoriak, ezért szerepük jelentős a közösség táplálkozási hálózatában (Schönrogge és mtsi, 1996a, b; Stone és mtsi, 2002). Annak ellenére, hogy a társbérlök a közösség szerves részét képezik (Askew, 1961; Stone és mtsi, 2002) és jelentős mértékben hozzájárulnak annak komplexitásához, ezekről tudunk a legkevesebbet (Sanver és Hawkins, 2000; Ács és mtsi, 2010).

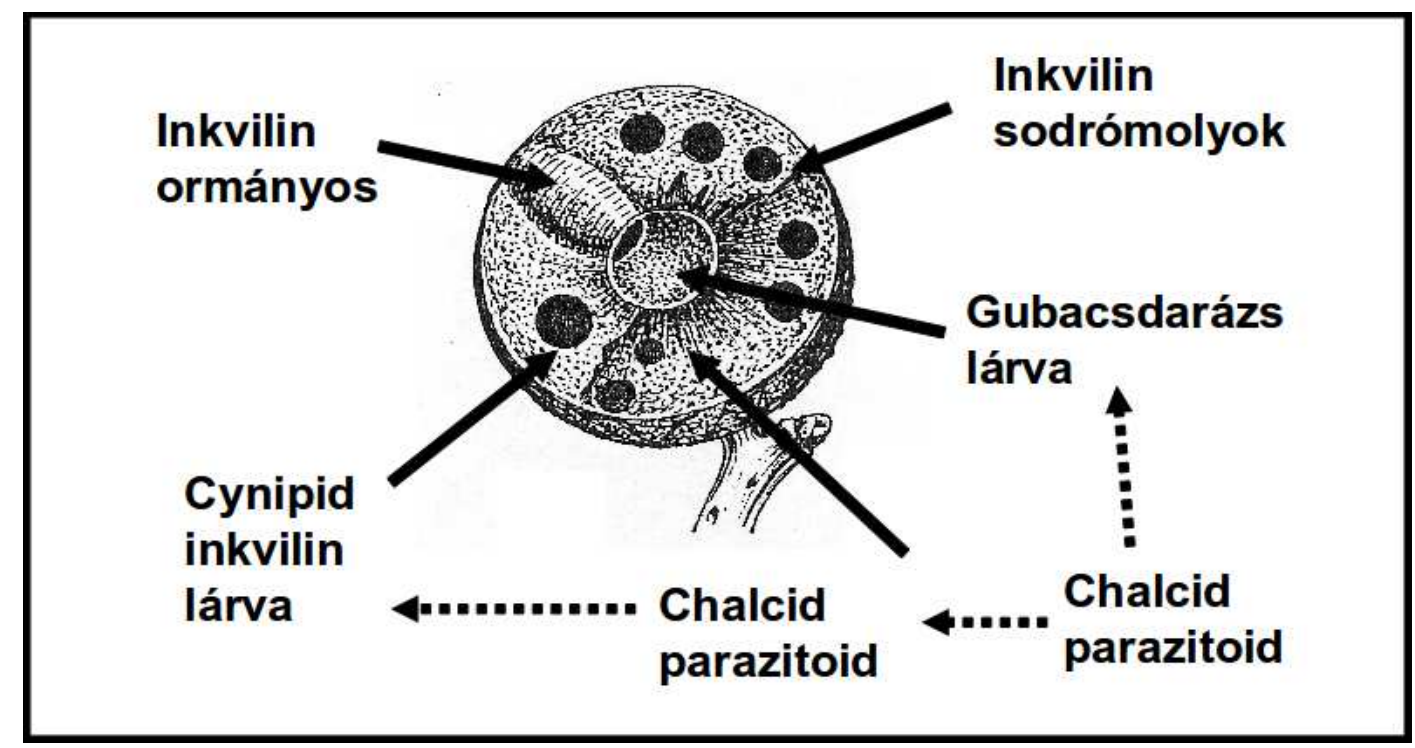

2. ábra A gubacsközösség tagjai és trofikus kapcsolataik. A tömör nyilak a gubacsban tipikusan elfoglalt helyre mutatnak, míg a szaggatott nyilak a trofikus kapcsolatok irányát jelölik.

\section{Inkvilin gubacsdarazsak (Synergini)}

A Cynipidae családon belül a fajok mintegy 15\%-a elvesztette gubacsindukáló képességét, más fajok által képzett gubacsokban fejlődik társbérlőként (Ronquist, 1994, Melika, 2006). Ezeket az inkvilin gubacsdarazsakat a Synergini tribuszba soroljuk (Hymenoptera: Cynipidae: Synergini). Jellemzőjük, hogy a növényi szövet differenciációját módosító képességük megmaradt, képesek lárvakamrát és az azt bélelő 
táplálószövetet létrehozni, akárcsak gubacsképző gazdáik.

A társbérlő életformát általában a kommenzalizmus egy típusának tekintik, mely átmenet képez a parazitizmus és a mutualizmus között (Askew, 1971). A synergini inkvilinek gubacsképző gazdáik (pl. Cynipini) közeli rokonai. A társbérlőségnek ezt a típusát agasztoparazitizmusnak nevezzük (Ronquist, 1994). Egy ettől független osztályozás szerint, a gubacsdarázs gazda lárvájára gyakorolt hatás alapján az inkvilineket három csoportra oszthatjuk (Duffet, 1968; Melika, 2006): (i) letális inkvilinek, melyek minden esetben a gubacsdarázs lárva halálát okozzák; (ii) nemletális inkvilinek, melyek sosem pusztítják el a gazdát és (iii) fakultatív inkvilinek, melyeknél lárvájuk lokalizációja döntő a gazdára gyakorolt hatást tekintve. Ha a társbérlő petéit a gubacsdarázs lárvakamrájának közvetlen közelébe rakja és lárvái gyorsabban fejlődnek, ez a gazda lárva pusztulásához vezethet. A synergini inkvilinek is növényevők, mint gubacsdarázs gazdáik, a gazda lárva mortalitás oka tehát a táplálék elvonása, ezért ezt tekintjük trofikus kapcsolatnak. Ugyanaz a társbérlő faj egy bizonyos gazda gubacsban letálisként viselkedhet, míg más gazda faj gubacsában nincs negatív hatással annak fejlődésére.

Néhány társbérlő képes befolyásolni a gubacs méretét és/vagy alakját is (PujadeVillar, 1991; Shorthouse, 1980). Ezek közül a Synophrus fajok arról nevezetesek, hogy sokáig gubacsindukálóknak tartották őket, gubacsdarázs gazdájukat sem sikerült sokáig azonosítani (Melika, 2006). A Synophrus fajok egyértelmüen társbérlök (morfológia és molekuláris taxonómia alapján is: Ronquist, 1994), melyek jelentős, a gubacsképzőkhöz hasonló mértékben képesek megváltoztatni a gazda gubacs kinézetét, formáját.

A Synergini tribusz tagjai csak ivarosan szaporodnak, körükben a nemzedékváltás ismeretlen. Nem letális fajoknál a kifejlett egyedek általában a darázs gazda kirepülését követően hagyják el a gubacsot, majd párzás után a nőstények fejlődésük viszonylag korai stádiumában levő gubacsokba rakják petéiket. Az ilyen gubacsok szövetei feltételezhetően még képlékenyek, ami előnyt jelent a társbérlő számára (Stone és mtsi, 2002). Minimálisak az ismereteink arról a mechanizmusról, mellyel az inkvilin nőstény megtalálja és kiválasztja a peterakáshoz megfelelő gubacsot - hasonlóan a növényi szövet speciális differenciációját előidéző mechanizmushoz.

Számos Synergini inkvilin faj gyakori Európában. Elterjedésük követi gubacsdarázs és tölgy gazdáik elterjedését. A legnagyobb területen megtalálható 
inkvilinek általában generalisták a gubacsdarázs gazdáikra nézve. Számos Ceroptres és Synergus faj széles gubacsdarázs gazdakörrel rendelkezik, például a Synergus gallaepiformis 45 különböző tölgygubacs gazdához és 6 gazdanövényhez köthető, és Nyugat-Európától egészen Oroszország legkeletibb részéig fellelhető. Azonban taxonómiai bizonytalanságok miatt és a synergini inkvilinekre vonatkozó újabb eredmények alapján ez módosulhat (Ács és mtsi, 2010).

A Synergini tribuszon belül az inkvilineket jelenleg 8 génuszra osztjuk:

- Ceroptres Hartig, 1840,

- Periclistus Förster, 1869,

- Rhoophilus Mayr, 1881,

- Saphonecrus Dalla Torre \& Kieffer, 1910,

- Synergus Hartig, 1840,

- Synophromorpha Ashmead, 1903,

- Synophrus Hartig, 1843 és

- Ufo Melika \& Pujade, 2005.

Számos taxonómiai és filogenetikai kérdés tisztázatlan a tribuszra vonatkozólag. Sok esetben bizonytalanok a fajhatárok (pl. Synergus umbraculus és Synergus hayneanus között), de a génuszok leszármazási kapcsolatai sem tekinthetők tisztázottnak. Morfológiai jellemzők alapján monofiletikusnak tartották ezt a csoportot, amely vélhetőleg a parafiletikus, lágyszárúakon gubacsot indukáló Aylacini csoportból származik (Ronquist, 1994). Ezen belül legközelebbi rokonai a Diastrophus és Xestophanes rendek (Ronquist, 1994; Ronquist és Liljeblad, 2001; Liljeblad, 2002; Nylander és mtsi, 2004a). Ezzel szemben a molekuláris filogenetikai eredmények arra utalnak, hogy ez az inkvilin csoport nem monofiletikus, hanem 3 független leszármazási vonalra osztható: (i) a rózsafélékhez kötődő Synophromorpha-Periclistus csoport, (ii) a tölgyhöz kötődő Ceroptres génusz és (iii) a Synergus komplex, amely a szintén tölgyhöz kötődő Synophrus, Saphonecrus és Synergus génuszokból, valamint az Afrikában Rhus fajokon élő Rhoophilus génuszból áll (Nylander és mtsi, 2004a; Melika, 
2006; Van Noort és mtsi, 2007; Pénzes és mtsi, 2009; Ács és mtsi, 2010) (3. ábra).

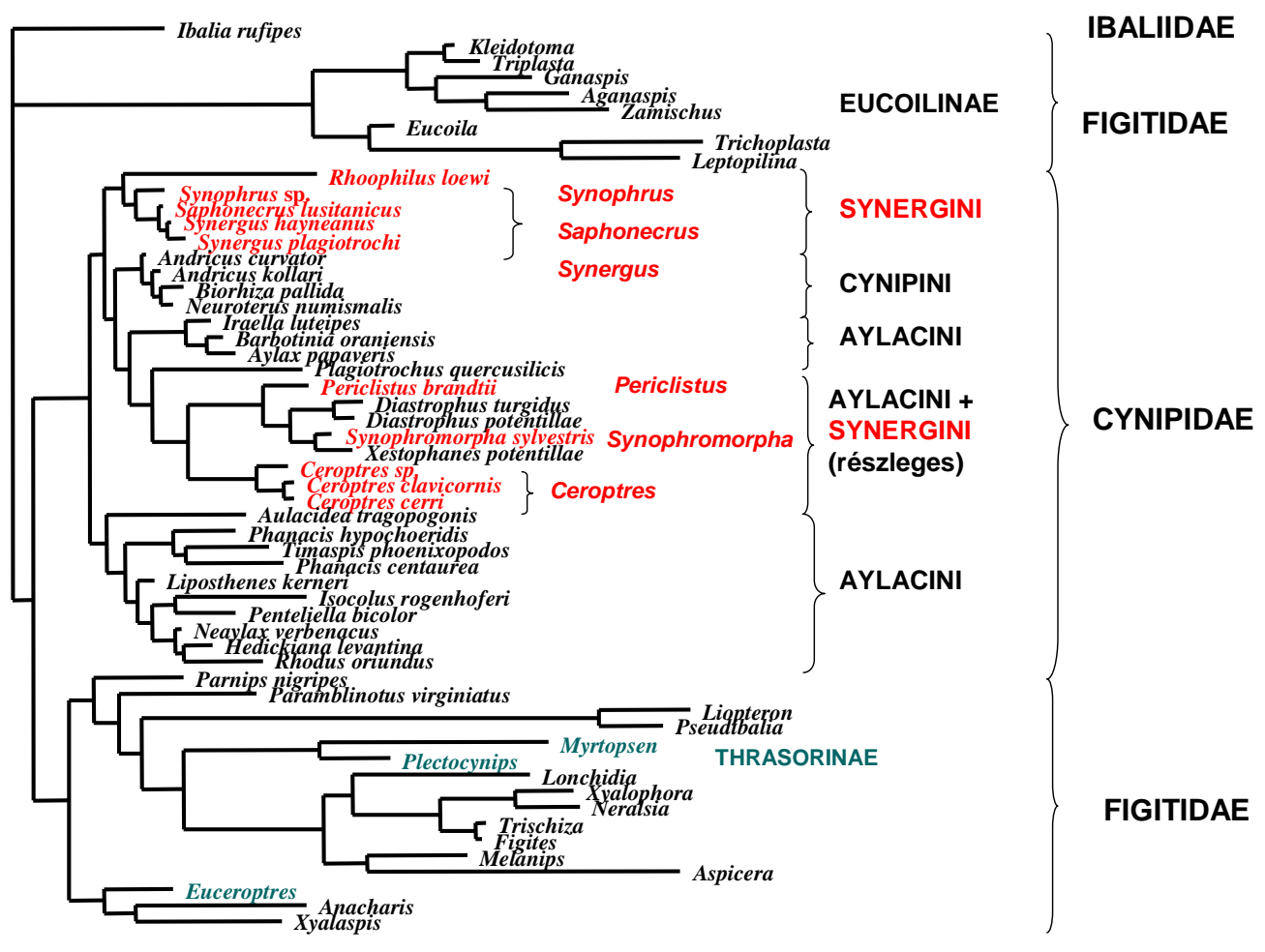

3. ábra A Cynipidae, Figitidae és Ibaliidae családok leszármazási viszonyait mutató 28S rDNS szekvencia alapú filogenetikai fa. Piros színnel jelöltük a Synergini tribusz 3 csoportjának fajait. Melika (2006) nyomán.

A Synophrus-Saphonecrus-Synergus leszármazási sort jelenleg négy alcsoportra osztjuk (Melika, 2006): (i) Synergus - ide tartozik a Synergus fajok többsége; (ii) a flavipes csoport - néhány Nyugat Palearktikus Synergus fajt sorolunk ide, melyek a Cerris szekcióhoz kötődnek; (iii) a haimi csoport - 3 Saphonecrus faj tartozik ide ( $S$. undulatus, haimi és irani), melyek szintén a Cerris szekcióhoz kötődnek és (iv) az előbbiek testvércsoportját képező, egy feltehetően korán elkülönülő ágat képviselő Synophrus csoport, melyhez néhány Saphonecrus fajt is sorolunk (Melika, 2006; Ács és mtsi, 2010; 4. ábra).

A Synophrus-Saphonecrus-Synergus leszármazási vonalon belül két csoportot elemeztünk, a Synophrus génuszt és a Synergus génusz egy faját. 


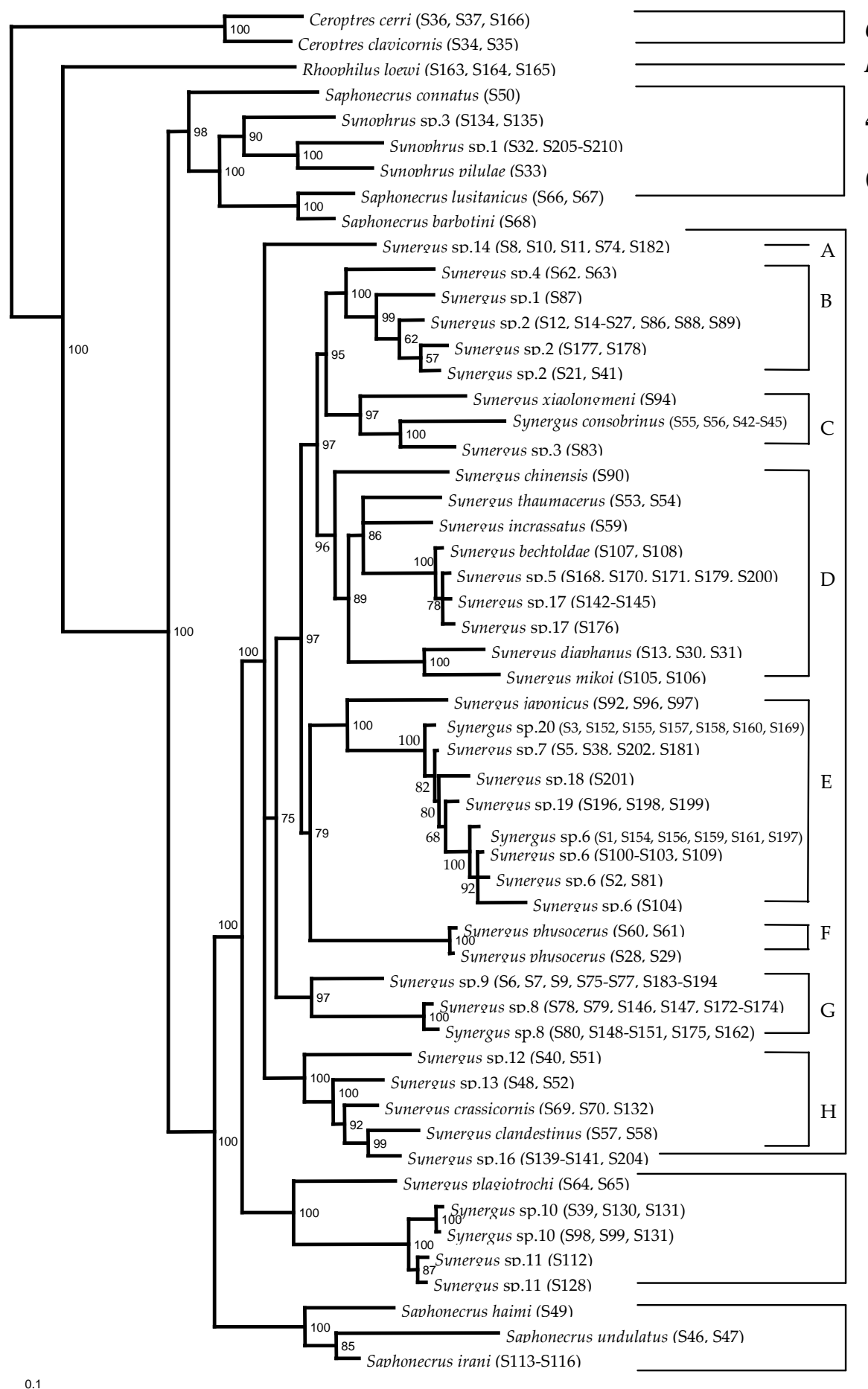

Ceroptres

Rhoophilus

4. Klád

(Synophrus)

\section{Klád}

(Synergus)

\section{Klád}

(Flavipes)

\section{Klád}

(Haimi)

4. ábra A Synergini tribusz rokonsági viszonyait szemléltető Bayes alapú konszenzus fa COI, cytb és 28S D2 stem és loop szekvenciák alapján. Melika (2006) nyomán. 


\section{A Synophrus génusz}

A tölgygubacs inkvilinek között talán a Synophrus fajok biológiájáról tudunk a legkevesebbet, beleértve a gubacsdarázs gazda kapcsolataikat, de földrajzi elterjedésük, taxonómiájuk és filogenetikai viszonyaik is kérdésesek (Melika, 2006). Eredetileg gubacsindukálóként írták le őket (Hartig, 1840), később morfológia alapján sorolták át e fajokat a Synergini társbérlők közé (Ronquist, 1994). Inkvilin életmódjukra a következő megfigyelés utal: Pujade-Villar és mtsi (2003) figyelték meg, hogy S. politus egyedek fejlődtek ki a nyár folyamán olyan gubacsokból, melyek az Andricus burgundus rügygubacsai helyén, feltehetően azokból alakultak ki. Ezek tipikus $S$. politus gubacsok, gömbszerüek, de szabálytalan alakúak és erősen elfásodottak, ami teljesen eltér az $A$. burgundus gubacsoktól.

A Synophrus fajok jellemzője a gazda gubacs fejlődésének jelentős megváltoztatása, amely egyedi sajátosság a tölgygubacs inkvilinek között. A Synophrus társbérlő mindig letális a rovar gazdára nézve. Ez feltehetően azzal magyarázható, hogy az inkvilin lárva sokkal gyorsabban fejlődik, lárvakamrája vagy kamrái egyszerúen elfoglalják a helyet. Ezek után a Synophrus lárva által kontrollált, továbbfejlődő gubacs morfológiája specifikussá válik az adott Synophrus fajra, akárcsak a tölgygubacsdarazsak esetében. A Synophrus politus vélhetöleg nem specifikus az A. burgundusra, ezzel magyarázható az a tény is, hogy a $S$. politus ott is tömegesen fordul elö, ahol A. burgundus nem él. Az újabb eredmények arra utalnak, hogy számos gubacsdarázs rendelkezik rejtett szexuális generációval, melynek gubacsai morfológiailag megkülönböztethetetlenek az A. burgundustól (Stone és mtsi, 2008). Feltehetően ezek a fajok is szolgálhatnak gazdaként a Synophrus fajoknak.

Minden ismert Synophrus faj a Cerris tölgyszekcióhoz kötődik, föként a Nyugat Palearktikumban elterjedtek. Azon gubacsok morfológiája, mérete és lokalizációja, melyekből Synophrus egyed nevelhető ki, igen változatos (5. ábra). Ezt a változatosságot magyarázhatja az, hogy az inkvilin sokféle gubacsdarázs gazda fajt támad. Ez kézenfekvőnek tünik, mivel a gubacsindukáló általában specifikus a növényi szervre (Cook és mtsi, 2002), a különböző növényi részeken fejlődő Synophrus gubacsok tehát más-más gubacsdarázs gazdától származhatnak. Másrészt ismert, hogy a gubacs morfológia jellegzetességeit a gubacsdarázs lárvája kontrollálja (Stone és Cook, 1998), emiatt az is lehetséges, hogy különböző Synophrus fajok, vagy leszármazási 
vonalak más-más irányba terelik a gubacsok fejlődését, ami a gubacs morfológia változatosságát eredményezheti.
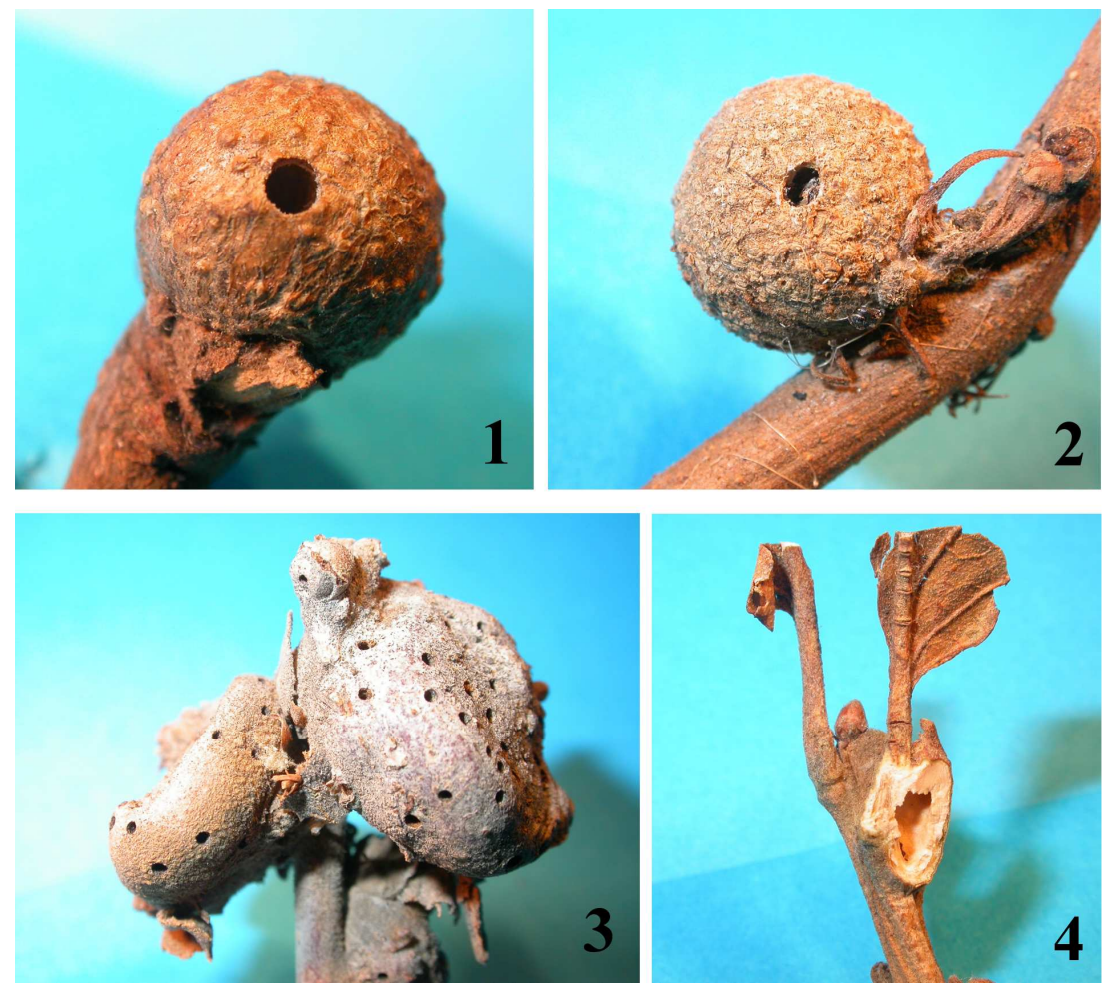

5. ábra Synophrus fajokra jellemző különböző gubacsváltozatok. 1. Synophrus pilulae, 2. S. politus, 3. S. olivieri, 4. S. hungaricus.

Vizsgálatainkat megelőzően 3 Nyugat Palearktikus Synophrus fajt tartottak számon: S. pilulae Houard, 1911, S. politus Hartig, 1843 és S. olivieri Kieffer, 1898. A génusz fajgazdagsága azonban régóta vitatott kérdés. Molekuláris filogenetikai eredmények arra utalnak, hogy a Synophrus fajok egy monofiletikus egységként különíthetők el, e klád testvércsoportját pedig a Saphonecrus génusz egy alcsoportja alkotja (4. ábra). A Synophrus fajok így a Synophrus-Saphonecrus-Synergus csoport egy korai divergenciájú leszármazási vonalának recens képviselői (Melika, 2006). 


\section{Synergus fajok}

A Synophrus-Saphonecrus-Synergus leszármazási vonalon belül legtöbb fajjal a Synergus génusz rendelkezik (4. ábra). Világszerte körülbelül 100 fajuk él, ebből hozzávetőleg 34 ismert a Nyugat Paleaarktikumban (Melika, 2006). Növényi gazdájuk túlnyomórészt valamilyen lombhullató Quercus faj. Mayr (1872) a Synergus génuszt morfológiai alapon két szekcióra osztotta. A morfológiai jellegek mellett egyes biológiai sajátságok is alátámasztották a két szekció meglétét. Az I. szekció fajainak közös jellemzője, hogy évente többnyire egy generációjuk fejlődik (univoltin), és csak ritkán letálisak a gubacsdarázs gazdára nézve. Ezzel szemben a II. szekcióban túlsúlyban vannak az évente két generációval rendelkező (bivoltin) és javarészt letális fajok. Ez utóbbi szekcióra még az is jellemző, hogy az ide sorolható fajok esetén a két generáció egyedei között jelentős a morfológiai különbség, tovább növelve a csoport taxonómiai bizonytalanságát.

Sok esetben csak egy fajkomplex azonosítható, ezen belül a fajok megkülönböztetése problémás, nincsenek jó diagnosztikus külső morfológiai jellegek. Az is sejthető volt, hogy bizonyos széles gazdaspecificitású fajok vélhetőleg kriptikus fajok komplexei (pl. Synergus umbraculus, S. hayneanus, S. pallipes: Melika, 2006). Mindezek szükségessé tették a génusz, illetve a tölgygubacs inkvilinek alaposabb filogenetikai vizsgálatát. Ács és mtsi (2010) molekuláris filogenetikai eredményei arra utalnak, hogy a fent említett Mayr szekciók mesterségesek, nem monofiletikusak, vagyis nincsenek összhangban a valós leszármazási kapcsolatokkal. Ezen kívül megerősítette kriptikus fajok kimutatásával azt a korábbi sejtést is, miszerint a Synergini csoport taxonómiai revízióra szorul, a diagnosztikai karaktereket át kell értékelni.

Egyike a problémás fajoknak a Synergus umbraculus Olivier, 1791, (6. ábra) mely az egyik legelterjedtebb tölgygubacs inkvilin a Nyugat Palearktikumban. Egy, vagy két generációja fejlődik évente más tölgygubacs darazsak gubacsaiban, kizárólag a Quercus génusz Quercus sensu stricto szekciójának fajain. Széles gazdaspektrumú, több mint 30 féle tölgygubacsból sikerült eddig kinevelni, leggyakrabban Andricus fajok aszexuális gubacsaiban fejlődik (Melika, 2006). Ács és mtsi (2010) eredményei alapján, amit jelenleg morfológiai alapon S. umbraculus-nak gondolunk, az molekuláris filogenetika alapján 4 különálló egység (MOTU, Molecular Operational Taxonomic 
Unit). Ezek közül a S. umbraculus-ként meghatározott minták több, mint 90\%-át a monofiletikus 19-es MOTU (Ács és mtsi, 2010) tartalmazza. A továbbiakban ez tekintjük a $S$. umbraculus fajnak.

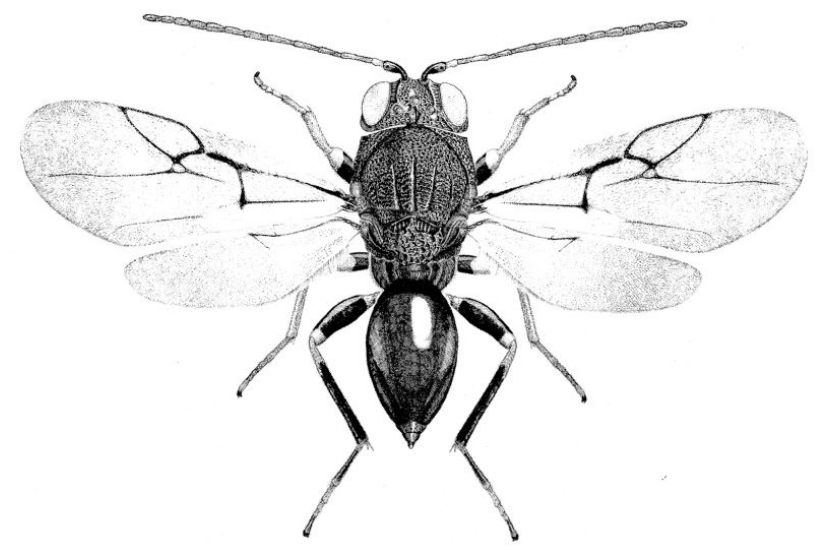

6. ábra Synergus umbraculus Olivier, 1791. Készítette: Foki Éva.

\section{Gazdaspecifikus genetikai differenciáció}

Herbivor és élősködő életmódot folytató rovarok diverzifikációja szimpatrikus körülmények között is végbemehet (Berlocher és Feder, 2002). Ez magyarázathatja azt a tekintélyes fajszintü diverzitást, amely így a különböző élőhelyekre, állati gazdákra (pl. parazitáknál), vagy növényi gazdákra (pl. fitofág rovaroknál) specializálódásnak a következménye. Számos fitofág rovar számára a gazdanövény az élöhelyet, a szaporodás helyét és az egyetlen táplálékforrást is jelenti egyben, így a gazda szerinti differenciáció az ökológiai fajképződés tipikus példája (Downie és mtsi, 2001). A gazdára történő specializáció genetikai differenciációt is eredményez, mivel a különböző gazdákra specializálódó leszármazási sorok között a génáramlás korlátozott. Ezeket a gazda specifikus leszármazási sorokat nevezzük gazda rasszoknak ("host race”), amely például egy parazita vagy fitofág élőlény genetikailag (és morfológiailag) elkülönült, szimpatrikus vagy allopatrikus populációit jelenti, melyek különböző gazdán élnek (Dres és Mallet, 2002).

A gazdanövény specifikus differenciáció (host associated differentiation, HAD) gyakori gubacsindukáló rovarok közt. A rovar és a gazdanövény közötti kapcsolat igen 
szoros, hiszen az állatnak a növény biokémiai rendszerét befolyásolva kell a növényt speciális képződmények (lárvakamra, táplálószövet) létrehozására kényszerítenie (Stireman és mtsi, 2005). A gazdák változatossága ezért kényszert jelenthet a herbivorok változatosságára. Ugyanezekből az okokból kifolyólag azt várjuk, hogy az inkvilinek esetében is elöfordulhat HAD a növényi gazdára nézve, mivel ezek is képesek a növényi szövetek módosítására.

Olyan trofikus kapcsolatok esetén is várható gazda szerinti differenciáció, ahol a kapcsolat valamilyen specializációt, szinkronizációt igényel (Forbes és mtsi, 2009). A társbérlőnek a gubacsképző gazda életciklusával is szoros szinkronban kell lennie, hogy a megfelelő időben megtalálhassa a peterakásra alkalmas stádiumban levő gubacsokat. A Nyugat Palearktikumban azokon a területeken él a legtöbb gubacsdarázs gazda faj, ahol a két tölgyszekció elterjedési területe átfed (1. ábra), például a Kárpát-medencében. Kizárólag ezeken a területeken fordulnak elő a komplex gazdaváltással jellemezhető gubacsindukáló Andricus fajok, melyek gubacsai kiemelkedően gazdag életközösségeknek adnak otthont (Melika, 2006). Ilyen módon a gazda szerinti szimpatrikus differenciáció lehetősége adott. Ugyanakkor ismert, hogy magas az évenkénti és térbeli variabilitás egy éven belül, akár a szomszédos fák között is jelentős lehet az eltérés a különböző gubacsdarázs gazdák előfordulási gyakoriságában. A különböző Andricus fajok gubacsai igen változatosak. Méretükben, külső és belső jellegeikben jelentősen eltérnek egymástól, ami befolyásolhatja a parazitoidok támadási gyakoriságát (Stone és Schönrogge, 2003; Bailey és mtsi, 2009). Ez alapján feltételezhetjük, hogy az inkvilinek peterakási sikerét is befolyásolhatják a gubacs külső jellegei. Például a gubacs keménységét tekintve, amely adaptáció lehet a parazitoidok ellen (Stone és Schönrogge, 2003), a következő sor állítható fel: Andricus lucidus < A.lignicolus $<$ A. infectorius $<$ A. kollari, amiben az utolsó a legkeményebb. Ezen kívül külső tüskék és ragacsos bevonat jelenlétében/hiányában is eltérőek ezek a gubacsok. Ezek az Andricus fajok hazánkban is gyakoriak.

\section{Filogeográfia}

Számos különböző tér és időléptékü folyamat formálja a közösségek és azok tagjainak diverzitását. Ezek közül a földtörténeti Negyedidőszak jégkorszakainak a 
Nyugat Palearktikum élővilágára, egyes fajok genetikai változatosságára gyakorolt hatása az egyik legrészletesebben vizsgált probléma (Hewitt, 1999; Schmitt, 2007). A lehülés, a jégtakarók kiterjedésével a mérsékelt égövi fajokat déli refúgiumokba számüzte. Ezek a területek Dél-Európában elsődlegesen az Ibériai félsziget, Appenini félsziget és a Balkán voltak (Hewitt, 1999) (1. ábra). Feltehetően számos populáció kipusztult a megfelelő élettér eltünése miatt az egyes jégkorszakok során (Thomas és mtsi, 2004). Az utolsó jégkorszakot követően a refúgiumok populációi népesítették újra be Európa többi részét (Hewitt, 1999; Schmitt, 2007). Egyre több bizonyíték támasztja alá, hogy a jól ismert dél-európai refúgiumokon kívül léteztek "kriptikus" refúgiumok északabbra is, ahol a mikroklíma ezt lehetővé tette (Deffontaine és mtsi, 2005; Ursenbacher és mtsi, 2006). Ezen területek kevésbé voltak jól körülhatárolhatóak és sürün lakottak, azonban kiemelkedő a szerepük az újra felmelegedő európai területek rekolonizációjában (Stewart és Lister, 2001; Varga, 2008; Provan és Bennett, 2008).

A Cynipidae család gubacsképzőivel kapcsolatban is rendelkezünk ismeretekkel a Negyedidőszak populáció-kiterjedéseire vonatkozólag. Tudjuk, hogy (i) az ibériai refúgium populációi általában genetikailag jól elkülönülnek és alacsonyabb diverzitásúak az appenini populációhoz képest; (ii) Észak-Európa újra benépesítése elsősorban Közép-Európa felől történt és nem Ibéria felöl (Rokas és mtsi, 2001; Stone és mtsi, 2007). Az is valószínüsíthető, hogy egy - a jégkorszakokhoz köthető populációmozgásokat megelőző - kelet-nyugat irányú elterjedés is volt, melynek forrása jelenlegi ismereteink szerint - az ősi, nagy genetikai diverzitású Anatóliai-fennsík és a mai Irán területe (Rokas és mtsi, 2003; Challis és mtsi, 2007; Stone és mtsi, 2007, Lohse és mtsi, 2010), azonban még távolabbi keleti forrás sem zárható ki. Ezt az elméletet "Out of Anatolia" hipotézisként tartjuk számon, amely értelmében gubacsdarázs leszármazási vonalak diverzifikációs központja a mai Törökország és Irán területe lehetett. Jóval kevesebb ismerettel rendelkezünk a gubacsközösség másik két szintjéről, a parazitoidokról és a társbérlőkről. Az eddig tanulmányozott parazitoidokra hasonló nagyléptékü filogeográfiai mintázat jellemző, mint a gubacsindukáló gazdáikra (Hayward és Stone, 2006, Nicholls és mtsi, 2010b), de egyes esetekben jelentős eltéréseket tapasztalunk: például a Megastigmus stigmatizans ibériai populációi átjutottak a Pireneusokon és benépesítették Franciaországot (Hayward és Stone, 2006).

A Kárpát-medence gubacsdarázs faunája igen sokszínű és viszonylag jól tanulmányozott (Melika, 2006). Néhány gubacsindukáló faj genetikai diverzitásáról is 
rendelkezünk ismeretekkel. (Stone és Sunnucks, 1993; Rokas és mtsi, 2003). Stone és Sunnucks (1993) az A. quercuscalisis faj esetén 7 polimorf allozim marker alapján Magyarország és Ausztria magas genetikai diverzitásáról számol be. Ez a diverzitás azonban nem struktúrált, a genetikai variabilitás térbeli differenciációja páronkénti $\mathrm{F}_{\mathrm{ST}}$ értékek alapján csekély mértékü. Rokas és mtsi (2003) citokróm b DNS szekvenciák és allozim markerek elemzésével az A. quercustozae gubacsdarazsat vizsgálta. Eredményei szerint a magyar populáció, a török után, a második legmagasabb szekvencia diverzitással jellemezhető. Allozim markerek alapján kimutatta, hogy a magyar populáció homogén, azonban két veszprémi minta az olasz, két soproni pedig a délnyugat török csoporttal mutat rokonságot. Eddig egyetlen tölgygubacs inkvilinről sem készült molekuláris alapú filogeográfiai vizsgálat.

A tölgygubacs közösség genetikai vizsgálatok egyik modellje, mert viszonylag zárt (így könnyen mintázható), és több trofikus szintet foglal magába (gazdanövény, gubacsindukálók és társbérlőik, parazitoidok, hiperparazitoidok), melyek genetikai diverzitásbeli mintázatai összevethetőek. Egy ilyen összehasonlításból olyan jelenségekre következtethetünk, mint például arra, hogy mennyire szorosak a fajok közötti asszociációk, mennyire gyakoriak a gazdaváltások, gazdacserék, mennyire követik az egyes trofikus szintek képviselői egymást elterjedésük során térben és időben - vagyis mennyire összehangolt az egyes trofikus szintek evolúciója. Ez összefüggést mutathat a Negyedidőszak éghajlatváltozásaival összefüggő flóra, és az ehhez kötött herbivór fauna kényszerített vándorlásaival is.

Egy közösség trofikus kapcsolatainak tanulmányozásához elengedhetetlen, hogy az azt alkotó fajok azonosítása egyértelmü legyen. Ehhez sok esetben molekuláris filogenetikai vizsgálatokra is szükség lehet, amely a morfológia alapú osztályozás mellett egy függetlennek tekintett eljárás a leszármazási kapcsolatok becslésére. 


\section{Célkitüzések}

Két inkvilin taxont választottunk ki részletesebb elemzésre. Kérdéseink illetve céljaink az alábbiak:

A Synophrus filogenetika:

- A génusz filogenetikai kapcsolatainak tisztázása.

A Synergus umbraculus genetikai változatossága:

- A kárpát-medencei populációk genetikai diverzitásának elemzése.

- A genetikai diverzitás értelmezése: kolonizációs történet. Arra a kérdésre keressük a választ, hogy a feltételezett dél-európai refúgiális régiók figyelembe vételével milyen filogeográfiai mintázat jellemző a fajra. Célunk ezáltal a Kárpát-medencét rekolonizáló populációk forrásának azonosítása.

- A genetikai diverzitás értelmezése: gubacsképzö gazdák szerinti differenciáció. Az inkvilin leszármazási sorok jelenlegi elterjedését befolyásolja a preferált növény és gubacsképző gazdáik elterjedése. Gazda rasszok kialakulhatnak egyes gubacsképző gazdákra, ezért céljaink közé tartozik a gazda szerinti differenciáció mértékének becslése is néhány gyakori gubacsdarázs gazdára vonatkozólag. 


\section{Anyag és módszer}

\section{Synophrus}

\section{Gyüjtés}

Magyarország 4 területén csertölgyről (Quercus cerris) gyüjtöttünk Synophrus gubacsokat: délnyugaton (Mecsek hegység), északnyugaton (Soproni hegység), északkeleten (Bükk hegység) és délkeleten (Szeged környékén). Ezeket a mintavételi régiókat egymástól legalább 200 km választja el. A gubacsokat elhelyezkedésük alapján a következő kategóriákba soroltuk: (i) csúcsrügyön vagy oldalrügyön található, (ii) fiatal hajtáson található, (iii) a levél föerén, vagy a levélnyélen található és (iv) a levélalapon található. A gubacsokból karantén alatt neveltük ki a darazsakat, majd 96\%os etanolban tároltuk az egyedeket további felhasználásig. A Nyugat Palearktikum más területeiről származó további Synophrus egyedeket is bevontunk a vizsgálatba (1. táblázat). Mivel az egyes kategóriák (gyüjtés helye, gubacs elhelyezkedése) minta elemszáma között jelentős különbségek voltak, illetve a különböző jellegek egyértelműen hozzá rendelhetőek egyes leszármazási sorokhoz (lásd eredmények), ezek összehasonlítását célzó statisztikai elemzést nem végeztünk.

A vizsgálatban felhasznált egyedek a következő intézmények gyüjteményeiben találhatóak meg: Magyar Természettudományi Múzeum Állattára, Budapest (Csősz Sándor); University of Barcelona, Spanyolország (Julie Pujade-Villar); Vas Megyei Talaj- és Növényvédelmi Szolgálat, Tanakajd (Melika George). A fajok leírását Melika George, Mikó István és Juli Pujade-Villar végezte (Pénzes és mtsi, 2009). 


\begin{tabular}{|c|c|c|c|c|c|}
\hline Faj & $\begin{array}{l}\text { Gazdanövény } \\
\text { (Quercus) }\end{array}$ & $\begin{array}{l}\text { Növényi } \\
\text { szerv }\end{array}$ & Gyüjtési hely & 28S D2 & COI \\
\hline $\begin{array}{l}\text { Synophrus } \\
\text { politus }\end{array}$ & $\begin{array}{l}\text { Q. cerris } \\
Q . \text { cerris } \\
Q . \text { cerris } \\
Q . \text { cerris } \\
\\
Q . \text { suber } \\
Q . \text { suber } \\
\text { ismeretlen }\end{array}$ & $\begin{array}{l}\text { levél, } \\
\text { rügy, } \\
\text { hajtás }\end{array}$ & $\begin{array}{l}\text { DK Magyarország (2) } \\
\text { DNy Magyarország (15) } \\
\text { ÉNy Magyarország (34) } \\
\text { ÉK Magyarország (8) } \\
\text { Olaszország, Piombino (1) } \\
\text { Olaszország, Savoria (8) } \\
\text { Törökország, Madenli (1) }\end{array}$ & $\begin{array}{l}5 \\
\text { EF583954 } \\
(\mathrm{EF} 487223) \\
\\
1(\mathrm{EF} 487223) \\
6(\mathrm{EF} 487223) \\
1(\mathrm{EF} 487223)\end{array}$ & $\begin{array}{l}58 \\
\text { EF579701 - EF579709 } \\
(\text { EF486971) } \\
1 \text { EF579711 } \\
8 \text { EF579712 } \\
1 \text { EF579710 }\end{array}$ \\
\hline S. pilulae & Q. cerris & rügy & $\begin{array}{l}\text { DK Magyarország (10) } \\
\text { DNy Magyarország (5) } \\
\text { ÉNy Magyarország (2) } \\
\text { ÉK Magyarország (1) }\end{array}$ & $\begin{array}{l}8 \\
\text { EF583958 } \\
(E F 487224)\end{array}$ & $\begin{array}{l}17 \\
\text { EF579713 - EF579716 } \\
(\text { EF486972) }\end{array}$ \\
\hline S. olivieri & $\begin{array}{l}\text { Q. brantii és } Q \text {. } \\
\text { libani }\end{array}$ & - & $\begin{array}{l}\text { Irán, Lorestan (4) } \\
\text { Irán, Kordestan (3) }\end{array}$ & $\begin{array}{l}1 \text { EF583959 } \\
1 \text { EF583959 }\end{array}$ & $\begin{array}{l}4 \text { EF579725 } \\
3 \text { EF579726 - EF579727 }\end{array}$ \\
\hline S.hungaricus & Q. cerris & $\begin{array}{l}\text { hajtás } \\
\text { (rügy, } \\
\text { levélnyél) }\end{array}$ & $\begin{array}{l}\text { DK Magyarország (12) } \\
\text { ÉNy Magyarország (1) }\end{array}$ & $\begin{array}{l}3 \text { EF583960 } \\
1 \text { EF583960 }\end{array}$ & $\begin{array}{l}13 \\
\text { EF579717 - EF579721 }\end{array}$ \\
\hline S. libani & $\begin{array}{l}\text { Q. cerris? vagy } \\
\text { Q.ithaburensis? }\end{array}$ & - & Libanon (2) & 2 EF583957 & 2 EF579724 \\
\hline S.hispanicus & Q. suber & - & Spanyolország (1) & (EF487225) & (EF486974) \\
\hline S. syriacus & $\begin{array}{l}\text { Q. libani } \\
\text { Q. libani } \\
\text { Q. ithaburensis? }\end{array}$ & - & $\begin{array}{l}\text { Irán, Kurdestan (3) } \\
\text { Irán, Kermanshah (1) } \\
\text { Szíria (3) }\end{array}$ & $\begin{array}{l}1 \text { EF583956 } \\
1 \text { EF583956 } \\
3 \text { EF583955 }\end{array}$ & $\begin{array}{l}3 \text { EF579722 } \\
1 \text { EF579722 } \\
3 \text { EF579723 }\end{array}$ \\
\hline
\end{tabular}

1. táblázat A molekuláris filogenetikai analízisben felhasznált Synophrus fajok. A "28S D2" és "COI” oszlopokban az új és zárójelben a letöltött szekvenciák GenBank azonosítóját, valamint az adott szekvenciával jellemezhető egyedek számát adtuk meg. A "Gyűjtési hely” oszlop a minták lelőhely szerinti eloszlását mutatja, zárójelben az adott lelőhelyhez rendelhető citokróm oxidáz szekvenciák számát adtuk meg. ? = kérdéses gazda. 


\section{DNS izolálás, amplifikálás, szekvenálás és a szekvenciák összeállítása}

DNeasy Tissue Kit-tel (QIAGEN) izoláltunk DNS-t 1-3 lábból, követve a gyártó ízeltlábúakra vonatkozó utasításait. A test fennmaradó részeit félretettuik későbbi morfológiai vizsgálatok elvégzése céljából, illetve bizonyító példánynak.

A mitokondrális citokróm oxidáz I alegység (COI) 658 bázispárnyi szakaszát a HCO-2198 5'-TAA ACT TCA GGG TGA CCA AAA AAT CA-3' és LCO-1490 5'GGT CAA CAA ATC ATA AAG ATA TTG G-3' (Folmer és mtsi, 1994) primereket alkalmazva szaporítottuk fel. A magi 28S D2 gén 565 bázispárnyi szakaszát a főbb kládokból kiemelt egyedekre felszaporítottuk a D2F és D2R primereket használva (D2F: 5'- CGTGTTGCTTGATAGTGCAGC-3' és D2R: 5'TCAAGACGGGTCCTGAAAGT-3', Hancock és mtsi, 1988). A PCR reakciókat $50 \mu 1$ végtérfogatban végeztük $2 \mu$ l templát DNS-t, $5 \mu$ 1 10X Taq puffert (Fermentas), $4 \mu \mathrm{l}$ $\mathrm{MgCl}_{2}$-t (25 mM, Fermentas), $1 \mu \mathrm{l}$ dNTP-t (10 mM, Fermentas), 0.6-0.6 $\mu$ l primert (10 pM), $0.4 \mu 1$ Taq polimerázt (5u/ $\mu 1$, Fermentas) és desztillált vizet felhasználva. A PCR reakciókat egy PTC-200 DNA Engine (MJ Research) készüléken végeztük a következő program alapján: első lépés $94{ }^{\circ} \mathrm{C}$ két percig, majd 35 ciklus $\left(94{ }^{\circ} \mathrm{C}\right.$ fél percig, 50 (COI) illetve $45^{\circ} \mathrm{C}$ (28S D2) 1 percig, $72{ }^{\circ} \mathrm{C}$ másfél percig), végül $72{ }^{\circ} \mathrm{C} 10$ percig. A kapott PCR termékből $5 \mu$ l-t 1\%-os agaróz gélen elektroforetizálva ellenőriztük a reakció sikerességét. A PCR terméket SAP (Shrimp Alkaline Phosphatase) és E. coli exonukleáz elegyével tisztítottuk. $20 \mu \mathrm{l}$ PCR termékhez $6.5 \mu \mathrm{l}$ SAP mixet adtunk, amely $1 \mu 1$ SAP-ot (1u/ $\mu 1$, Fermentas), $2 \mu 1$ 10X SAP puffert (Fermentas), $1.5 \mu 1$ E. coli ExoI exonukleázt (20u/ $\mu 1$, Fermentas) és $2 \mu 1$ 10X ExoI puffert tartalmazott. Ezután a mintákat 40 percig $37^{\circ} \mathrm{C}$-on, majd 20 percig $80{ }^{\circ} \mathrm{C}$-on inkubáltuk. Bizonyos esetekben a PCR terméket közvetlenül gélből tisztítottuk Ultrafree-DA kittel (Millipore) a gyártó utasításait követve. A minták nagy részénél (az összes 28S D2 és a COI 90\%-a) a tisztított PCR terméket mindkét irányból megszekvenáltuk, ehhez ABI BigDye v3.1 Terminator Cycle Sequencing kittet használtunk (Applied Biosystems), majd a kapott terméket egy ABI Prism 3100 Genetic Analyzer (Applied Biosystems) típusú kapilláris szekvenátoron futtatuk. A kromatogramokat a Staden Package (Staden és mtsi, 2000) programcsomaggal állítottuk össze. Az új haplotípusokat a GenBank adatbázisába hozzáférhetővé tettük (EF583954-EF583960 és EF579701-EF579727, 1. táblázat).

További 4 Synophrus COI szekvenciát használtunk fel a GenBank 
adatbázisából: egy-egy észak-magyarországi $S$. politus és $S$. pilulae, egy spanyolországi S. hispanicus és egy Algériából származó Synophrus minta (gazda: Q. suber, 2001; EF486973) szekvenciáját. A Synergini tribuszból a következő rokon fajok szekvenciáit használtuk fel egy másik viszgálatunkból (Ács és mtsi, 2010): Saphonecrus haimi (EF486879, EF487126), Saphonecrus undulatus (EF486882, EF487132), Saphonecrus connatus (EF486878, EF487125), Saphonecrus barbotini (EF486877, EF487124), Saphonecrus lusitanicus (EF486880, EF487130) és Rhoophilus loewi (EF486875, $\mathrm{EF} 487122)$.

\section{A szekvenciák elemzése}

A 28S D2 szekvenciákat a ClustalX v1.83 (Thompson és mtsi, 1994) szoftverrel illesztettük először az alapértelmezett beállításokkal, majd tovább finomítottuk a maximális hasonlóság elérése érdekében. Az összes gap pozícióját úgy rögzítettük, hogy kongruensek legyenek a Cynipini szekvencia illesztésekkel (Nylander és mtsi, 2004b). Az 565 bázispárnyi illesztett szekvenciában a gap-eket 14 különböző bináris karakterként kódoltuk Simmons és Ochoterena (2000) gap kódolási eljárása alapján (simple gap coding). A COI szekvenciák illesztése egyértelmü volt, mivel az összes szekvencia ugyanolyan hosszú, és nem tartalmaz gap-et (658bp). Fehérjére lefordítva ellenőriztük, hogy kódoló szekvenciák lehetnek-e. A minták mintegy 10\%-nál egy rövidebb COI szakaszt használtunk ( $\mathrm{kb} 480$ bp), azonban ezeket a mintákat csak a fö leszármazási vonalak azonosítására használtuk, mivel az eredmények alapján ez elegendőnek bizonyult a besoroláshoz. Csak a teljes hosszúságú COI haplotípusokat használtuk fel a fajon belüli diverzitás számolásához és a filogenetika becsléséhez.

A filogenetikai rekonstrukcióhoz a megfelelő szubsztitúciós modellt a MrModeltest 2.2 (Nylander, 2004c) szoftverrel választottuk ki. A filogenetikai becslést Bayes alapú módszerrel végeztük (MrBayes 3.1.2, Ronquist és Huelsenbeck, 2003) a következő kombinációknak megfelelöen: COI, COI kodon pozíciók alapján partícionálva, 28S D2 gap partícióval és anélkül, valamint kombinált COI - 28S D2 gap nélkül - 28S D2 gapekkel. Minden elemzésben a partíciókra vonatkozó paramétereket egymástól függetlennek tekintettük, beleértve a ráta paramétereket is, amelyek becslése a rekonstrukció része. A 28S D2 gapeket restrikciós adatként definiáltuk, a szoftver 
kézikönyve által javasolt eljárást követve. Az analízis során a fák terének elemzésére két független futtatást végeztünk, egyenként 4 párhuzamosan futó lánccal. A láncokat kétmillió generációig futtattuk, minden századikat mintázva, az első 750000 generációt burn-in-nek tekintve. A Markov-láncok konvergenciája minden elemzésben kielégítő volt. Az eltérések szórása 0.007 alatt maradt, illetve a PSRF (potential scale reduction factor) statisztika értéke az 1.000-1.002 tartományban volt minden paraméterre. Más módszerekkel is nagyon hasonló (kongruens topológia) eredményt kaptunk, így csak a Bayes alapú analízis eredményeit tárgyaljuk. (Az egyéb módszerek/szoftverek: maximum likelihood analízis/PhyML szoftver (Guindon és Gascuel, 2003); maximum parszimónia és neighbour joining/MEGA3 (Kumar és mtsi, 2004)).

\section{Synergus umbraculus}

\section{Gyüjtés}

Graham N. Stone gyüjtéséből Spanyolországtól Iránig, 55 mintavételi helyröl származó S. umbraculus egyedeket kaptunk, lefedve az összes vélt nyugat palearktikumi refúgiumot és a gubacsdarázs gazdák széles skáláját (7. ábra, 1. függelék). Hazánk területén a gyüjtést mi végeztük, további 18 hellyel bővítve a mintavételi pontok számát. Így a mintavétel, céljainknak megfelelően, Magyarországon volt a legintenzívebb, lehetővé téve a genetikai diverzitás térbeli mintázatának és az esetleges gazdaspecifikus differenciáció vizsgálatát. A gubacsokat egyenként fiolákba helyeztük, és karantén alatt neveltük ki a darazsakat, melyeket ezután 96\%-os etanolban -20 ${ }^{\circ} \mathrm{C}$-on tároltunk további felhasználásig. Morfológiai alapon történő határozás után az egyedeket MOTU-khoz rendeltük a magi 28S D2, valamint a mitokondriális citokróm oxidáz és citokróm b gének szekvencia-információi alapján, mivel ez Ács és mtsi (2010) alapján elegendőnek bizonyult azok azonosításához. 


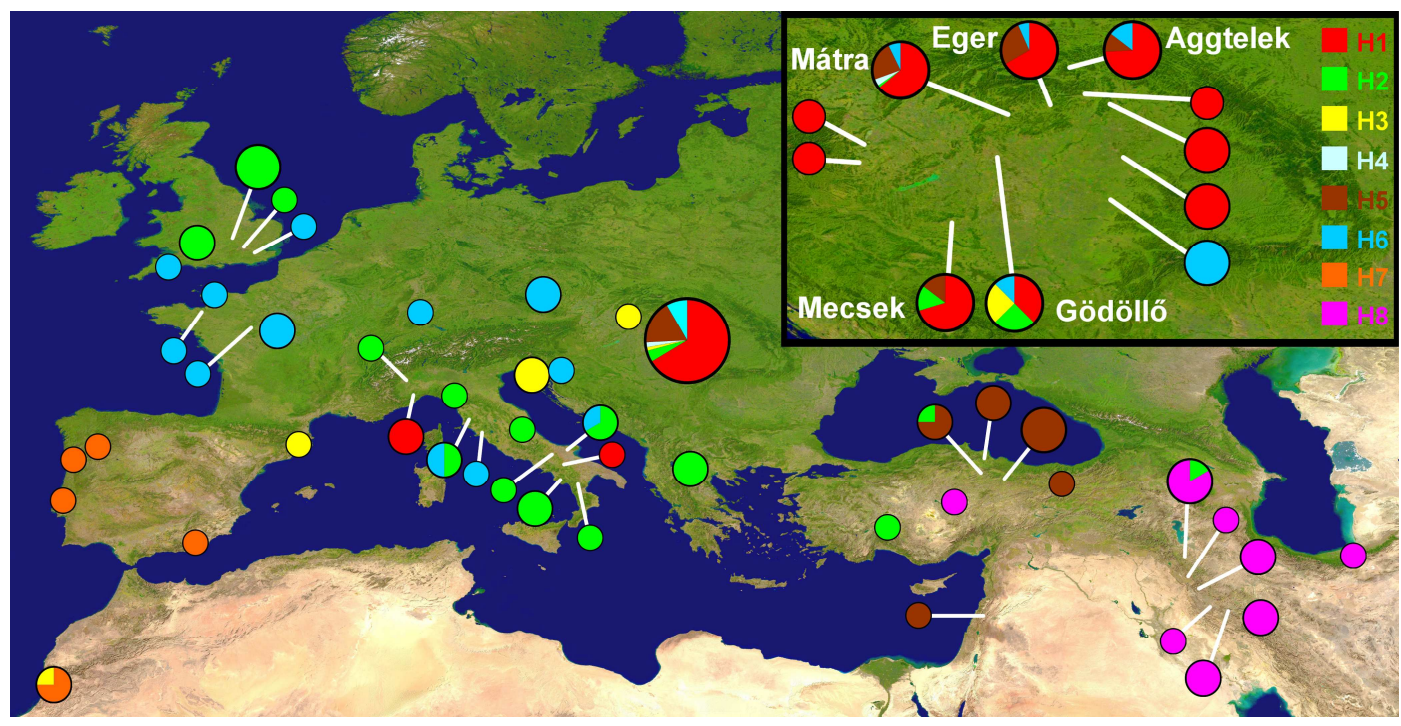

7. ábra Synergus umbraculus mintavételi helyek a Nyugat Palearktikumban. A színes körök egy, vagy több, egymáshoz közeli mintavételi helyet és a helyre jellemző citokróm b haplocsoport eloszlást jelölik. A jobb felső sarokban a Kárpát-medence kinagyított képe látható.

\section{DNS izolálás, amplifikálás, szekvenálás és a szekvenciák illesztése}

Minden felhasznált egyedre megszekvenáltunk a citokróm b (cytb) gén egy 697 bázispár hosszúságú szakaszát. Azért a cytb szakaszt választottuk, mert korábbi munkák (Ács és mtsi, 2010) azt mutatták ki, hogy a tölgygubacs inkvilinek esetében a fajon belüli variabilitás erre a vizsgált markerre a legnagyobb. Másrészt így fennáll a lehetősége annak, hogy eredményeinket összehasonlítsuk számos gubacsindukáló darázsra vonatkozó adattal (Hayward és Stone, 2006; Challis és mtsi, 2007; Stone és mtsi 2007; Stone és mtsi 2009), melyek ugyanezen a markeren alapulnak. Minden fö cytb haplocsoportból kiválasztottunk néhány egyedet, melyek COI (658 bp, n=18) és 28S D2 (489 bp, n=15) génszakaszát is megszekvenáltuk annak érdekében, hogy ellenőrizzük a cytb haplocsoportokkal kongruens mintázatot mutatnak-e. Feltételezzük, hogy ha kongruensek az egyes génekre vonatkozó génfák, ezek egyben a populációk történetét tükrözik.

DNS izolálást egyrészt a DNeasy Tissue Kit-tel (QIAGEN), másrészt egy olcsó, de hatékony chelex alapú módszerrel végeztünk (Hayward és Stone, 2006). A mitokondriális citokróm b gén egy 697 bp hosszúságú szakaszát a CP1B/CP2C primer 
párral polimeráz láncreakcióban (PCR) szaporítottuk fel (CP1B 5'-AAT TTT GGA TCT CTT TTA GG-3', CP2C 5'-GGT ATT TGT TTA ATT ATT CAA A-3'). Ezt a primer párt speciálisan Synergus umbraculus-ra terveztük a Harry és mtsi (1998) által közölt CP1/CP2 primerek módosításával. Ez a cytb fragment lefedi azt a 433 bp hosszú szakaszt, melyet számos gubacsdarázs esetében sikeresen használtak (pl. Rokas és mtsi, 2001, 2003; Challis és mtsi 2007; Stone és mtsi 2007, CB1 és CB2 primerek). A COI (658 bázispár) és 28S D2 (489 bázispár) markerek amplifikálásához ugyanazokat a primerpárokat használtuk, mint a Synophrus esetében.

A polimeráz láncreakciókat (PCR) $25 \mu$ l végtérfogatban hajtottuk végre $0,25 \mu 1$ (5U/ $\mu \mathrm{l})$ Taq DNS polimeráz (Fermentas), 2,5 $\mu \mathrm{l}$ 10X Taq puffer, 2,0 $\mu 1 \mathrm{MgCl}_{2}$ (25 $\mathrm{mM}), 0,5 \mu \mathrm{d} \mathrm{dNTP}(10 \mathrm{mM}), 0,5-0,5 \mu \mathrm{l}$ primerek (20 pmol), 2,0 $\mu 1$ templát DNS és 16,75 $\mu 1$ desztillált víz felhasználásával. A primerek hibridizálási hőmérséklete 28S D2re $45{ }^{\circ} \mathrm{C}$, COI-ra $50{ }^{\circ} \mathrm{C}$, cytb-re $46{ }^{\circ} \mathrm{C}$ volt. A PCR terméket $1 \%$-os agaróz gélen futtattuk, a gélből Millipore Ultrafree®-DA kittel visszaizoláltuk, majd a PCR terméket szekvenáltattuk (MWG-Biotech AG). A haplotípusok DNS szekvenciáit a GenBank adatbázisába hozzáférhetővé tettük (GU386377-GU386442, 1. függelék).

A szekvenciák illesztését a ClustalX v1.83 (Thompson és mtsi, 1994) programmal végeztük. A cytb szekvenciák illesztése egyértelmü volt, nem tartalmaztak gap-et, fehérjére lefordítva sincs okunk feltételezni, hogy esetleg magi másolatok. A teljes statisztikai elemzést kizárólag a cytb szekvenciákra végeztük el (lásd alább). A COI és 28S D2 génszekvenciák filogenetikai rekonstrukcióját a Mega 4 (Tamura és mtsi, 2007) programmal végeztük, minimum evolúció módszert és maximum composite likelihood modellt használva. A COI régió 93 polimorf pozíciót tartalmazott és egyértelmüen támogatta a cytb marker által rekonstruált leszármazási vonalakat. A $28 \mathrm{~S}$ D2 szekvenciák alacsony variabilitást mutattak, mindössze 3 haplotípust találtunk.

\section{Statisztikai módszerek}

Adataink konvertálását és egyszerübb számításokat az R 2.9.0 (R Development Core Team, 2009) programmal végeztük. A populáción belüli variabilitást a következő mérőszámokkal jellemeztük: haplotípusok száma, egyedi haplotípusok száma (amely csak egy mintában fordul elö), Nei géndiverzitás (h), nukleotid diverzitás ( $\pi$ ) és kétféle 
genetikai távolság (lásd alább). A diverzitás indexek becsléséhez a DnaSP 5.00.07 (Librado és Rozas, 2009) programot használtuk. Ugyanezekkel a mérőszámokkal jellemeztük az egyes haplocsoportok diverzitását is. Az egyes földrajzi régiókra vonatkozó mintanagyságok jelentősen különböznek, ezért a gén és nukleotid diverzitás értékek hasonlóságát nem teszteltük.

A fa alapú filogenetikai rekonstrukciós módszerek alkalmazhatóságát a SPLITSTREE 4.8 (Huson és Bryant, 2006) programmal teszteltük. Ez 95\%-os megbízhatósági szintü hálózattal történt, a szoftverben rendelkezésre álló legösszetettebb modellt használva $(\mathrm{HKY}+\mathrm{I}+\mathrm{G}$ - Hasegawa-Kishino-Yano modell invariábilis pozíciókkal és gamma eloszlással), ez állt legközelebb a modellszelekciós eljárás által is javasolt modellhez (lásd alább). A megbízhatóságot 200 bootstrap ismétléssel, valamint NeighbourNet és "equal angle splits” módszerrel vizsgáltuk. A cytb haplotípusokból ily módon generált hálózat nem tartalmazott multifurkációkat a főbb haplocsoportok tekintetében, ami arra utal, hogy erős filogenetikai szignál van az adatokban, támogatva a fa alapú módszerek használhatóságát.

A haplotípusok közötti leszármazási kapcsolatokat Bayes alapú módszerrel becsültük meg a BEAST 1.4.8 (Drummond és Rambaut, 2007) szoftverrel "születéshalál" (birt-death) priort és molekuláris órát (strict clock) alkalmazva. Ez utóbbi a divergencia idők becslése miatt volt szükséges. Az adatainkra legjobban illeszkedő nukleitod szubsztitúciós modellt (General Time Reversible modell invariábilis pozíciókkal és gamma eloszlással - GTR+I+G) a MrModeltest 2.3 (Nylander, 2004c) programmal választottuk ki. Az elemzést kodon pozíciók szerint partícionálva végeztük. A szekvencia divergencia kalibrálásához a széles körben használt $1.15 \%$ szekvencia divergencia/millió év/leszármazási vonal értéket használtuk (Brower, 1994). A ráta alkalmassága vitatható, pusztán azért használjuk, mert lehetőséget ad arra, hogy eredményeinket összevethessük korábbi gubacsdarazsakra és parazitoidjaikra vonatkozó munkákkal, melyek szintén a Brower-féle rátán alapulnak (pl Challis és mtsi, 2007, Hayward és Stone, 2006). A BEAST futásokat 50 millió generációig folytattuk, minden tízezredik generációból vettünk mintát. A Markov-láncok konvergenciáját az ESS (effective sample size) értékek alapján a Tracer 1.4 (Rambaut és Drummond, 2007) programmal ellenőriztük. Az egyes futások eredményeit a LogCombiner eszközzel egyesítettük, az első 10\%-ot burn-in-nek tekintve. A haplocsoportok egy részére (H1, H2, H8, részleteket lásd az Eredmények részben) statisztikus parszimónia hálózatot 
készítettünk - 95\% összeköttetési határral a TCS program segítségével (Clement és mtsi, 2000) - azok kapcsolatának tisztázása céljából.

A térbeli genetikai differenciációt két léptékben vizsgáltuk. Egyrészt a 73 mintavételi helyet 6 régióba soroltuk az ismert refúgiumok alapján: az Ibériai-félsziget és Marokkó (Ibéria, egyedszám ( $\mathrm{n}=9$ ), Olaszország ( $\mathrm{n}=20)$, a Kárpát-medence $(\mathrm{n}=158)$, Törökország és Libanon (TL, $n=13)$, Irán ( $n=18)$, valamint a Brit-szigetek (UK, $n=11)$ mint északi posztglaciális populáció (7. ábra, 2. táblázat). A Francia- és Németországból (együtt $\mathrm{FG}, \mathrm{n}=6)$, valamint Görögországból $(\mathrm{n}=4)$ származó mintákat a régió szintü statisztikai elemzésben nem használtuk fel az alacsony minta elemszám miatt. 3 Horvátországból származó mintát az olasz régióhoz soroltunk az olaszokkal egyező haplotípus miatt, feltételezve, hogy az Alpok a fö fizikai barrier ebben a régióban. Az egyetlen libanoni mintát Törökországhoz soroltuk a haplotípusok azonossága miatt. Az iráni és a török régió különválasztását az indokolta, hogy az Anatóliai Diagonál e két régió között húzódik (1. ábra).

Másrészt Magyarországot a következő 5 régióra osztottuk, hogy a genetikai variabilitást ebben a térléptékben is elemezhessük: Mecsek ( $n=27)$, Gödöllő $(n=8)$, Mátra (n=69), Eger $(n=15)$ és Aggtelek $(n=27)$ (7. ábra, 3. táblázat). Több magyarországi minta kimaradt ebből az elemzésből, mert egyik régióba sem sorolható be egyértelmüen.

A genetikai differenciációt AMOVA módszerrel (Analysis of Molecular Variance, Excoffier és mtsi, 1992) vizsgáltuk, amihez kétféle genetikai távolságot vettünk alapul: (i) a szekvenciák közötti nem korrigált páronkénti távolságot (ptávolság) és (ii) a páronkénti patrisztikus távolságot. Az utóbbit a BEAST eredményeként kapott fa alapján, a Patristic szoftverrel (Fourment és Gibbs, 2006) számoltuk ki. A távolságok elemzését R-ben végeztük. Az AMOVA számításokat az $\mathrm{R}$ VEGAN 1.15-2 csomagjának (Oksanen és mtsi, 2009) “ADONIS” függvényével végeztük el. A térbeli heterogenitás szignifikanciájának tesztelése permutációs tesztekkel történt, 5000 random permutációt alkalmazva, illetve 1000 permutációt végeztünk a páronkénti összehasonlítások során. A variancia komponensek becslése során a populációkat egy csoportba soroltuk, a $\Phi_{\mathrm{ST}}$ becslése ez alapján történt (Excoffier és mtsi, 1992; Weir, 1996, a legegyszerübb hierarchikus szerkezetet tételezve fel).

A tölgygubacs gazda specificitás tesztelésére szintén AMOVA-t végeztünk. 
Sajnos a több éven keresztül végzett intenzív hazai mintázás ellenére sem sikerült a különböző régiókból származó gubacsokból elegendő Synergus umbraculus egyedet kinevelni ahhoz, hogy a gazdaspecificitást és a térbeli genetikai differenciációt együtt tesztelhessük. Így a gazdaspecificitás tesztet csak a Mátra régióból származó azon mintákra végeztük el $(\mathrm{n}=55)$, melyeknél a gubacs gazda azonosítása egyértelmü volt. A következő 4 gubacsdarázs faj aszexuális generációjának gubacsaiból származó $S$. umbraculus egyedeket használtuk fel: Andricus infectorius $(\mathrm{n}=7)$, A. kollari $(\mathrm{n}=15)$, A. lucidus $(\mathrm{n}=15)$ és A. lignicolus $(\mathrm{n}=18)$. Az összes gazdaspecificitás vizsgálatba bevont gubacs rügy eredetü. 


\section{Eredmények}

\section{$\underline{\text { Synophrus }}$}

\section{Molekuláris filogenetika és diverzitás}

A szekvencia analízishez összesen 118 COI és 37 28S D2 szekvenciát használtunk fel (1. táblázat). A MrModeltest 2.2 (Nylander, 2004c) szoftver által javasolt GTR $+\mathrm{I}+\mathrm{G}$ (General Time Reversible modell invariábilis pozíciókkal és gamma eloszlással) szubsztitúciós modellt használtuk a COI adatokra, SYM+I (Szimmetrikus modell invariábilis pozíciókkal) modellt a 28S D2 szekvenciákhoz. A COI szekvenciák a Synophrus génusz monofiletikusságát támogatják, és magas megbízhatósági értékkel további csoportok elkülönítését teszik lehetővé (8. ábra).

A mindkét lokuszt alapul vevő filogenetikai rekonstrukció az eddig leírt 3 Synophrus faj (S. pilulae, S. politus, S. olivieri) mellett további új fajok jelenlétét támasztja alá (9. ábra). Ezen tudományra új fajok elkülönítése és leírása, új diagnosztikus morfológiai karakterek megállapításával és határozókulcs felállításával megtörtént, az önálló leszármazási sorokat a molekuláris filogenetika is alátámasztotta (Pénzes és mtsi, 2009), vagyis a molekuláris filogenetikai rekonstrukcióban elkülönülő bizonyos leszármazási vonalak faji státuszt nyertek. Az új fajok: Synophrus hungaricus Melika és Mikó, 2009, S. libani Melika és Pujade-Villar, 2009, S. syriacus Melika, 2009 és S. hispanicus Pujade-Villar, 2009. A morfológiai és taxonómiai munkát George Melika, Mikó István és Juli Pujade-Villar végezte. Ezen dolgozat tárgyát csak a molekuláris filogenetikai eredmények képezik.

A COI filogenetika alapján (8. ábra) két csoport különíthető el. Az elsőbe tartoznak a $S$. hispanicus, $S$. hungaricus és $S$. olivieri fajok, a másodikba pedig a $S$. pilulae, S. politus, S. libani és a S. syriacus. A Synophrus syriacus és S. libani testvércsoportok, és együtt monofiletikusak a $S$. politus fajjal, míg a $S$. pilulae egy korábbi divergenciájú leszármazási sort képvisel, testvérfaja az előbbi csoportnak. A 28S D2 szekvenciák alacsony diverzitást mutattak, mindössze öt haplotípust tudtunk elkülöníteni a génuszon belül. A COI alapján elkülönült $S$. olivieri $-S$. hispanicus $-S$. hungaricus leszármazási vonal ugyanazzal a 28S D2 haplotípussal jellemezhető. 


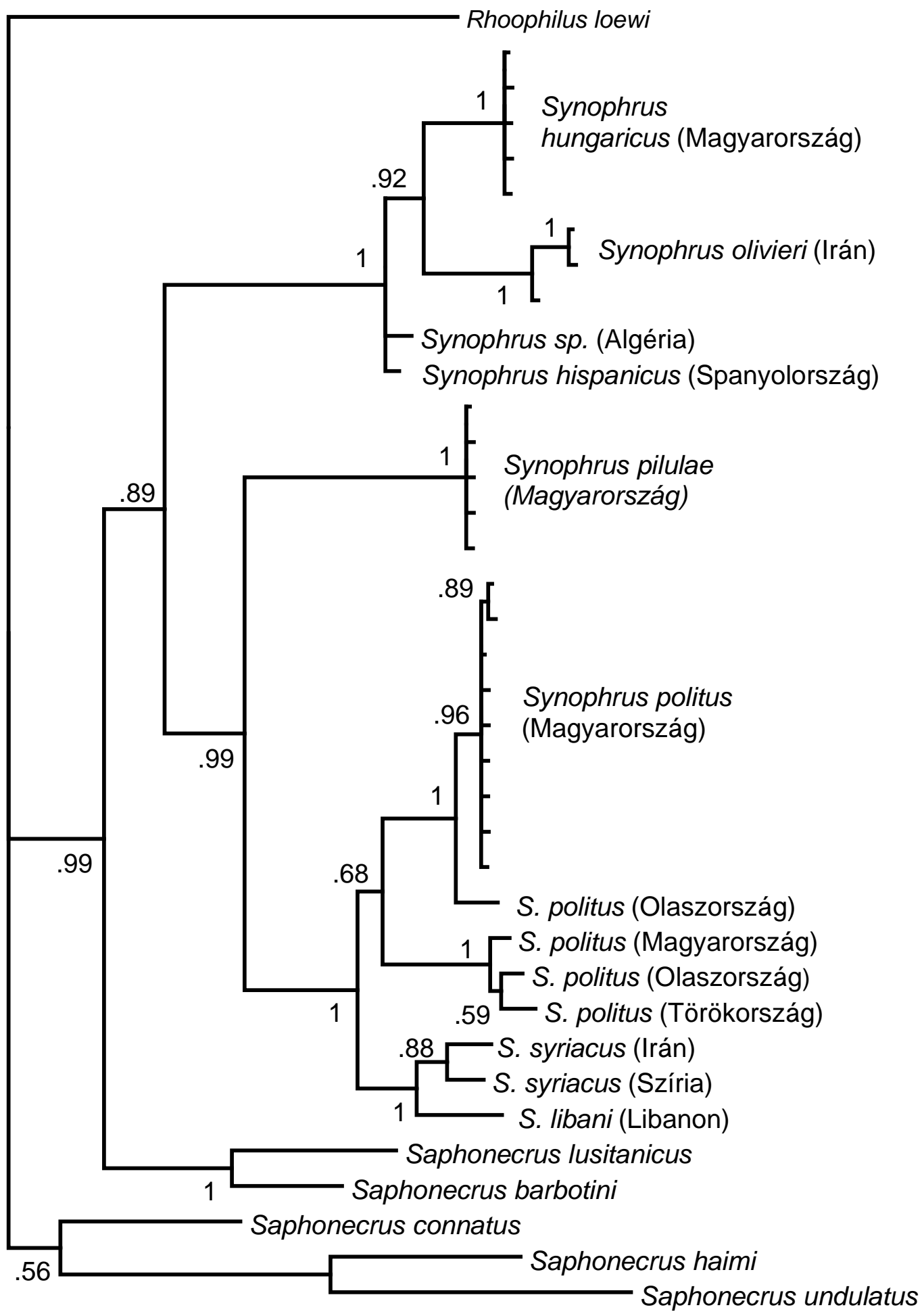

8. ábra A Synophrus, Saphonecrus és Roophilus génuszok citokróm oxidáz alapú filogenetikája. 50\% majority-rule konszenzus fa, amely Bayes analízissel, a nem partícionált adatszett alapján készült. Külcsoportnak a Roophilus loewi fajt tekintettuik. Az elágazási pontok felett a posterior valószínüség értékeket tüntettuik fel. 


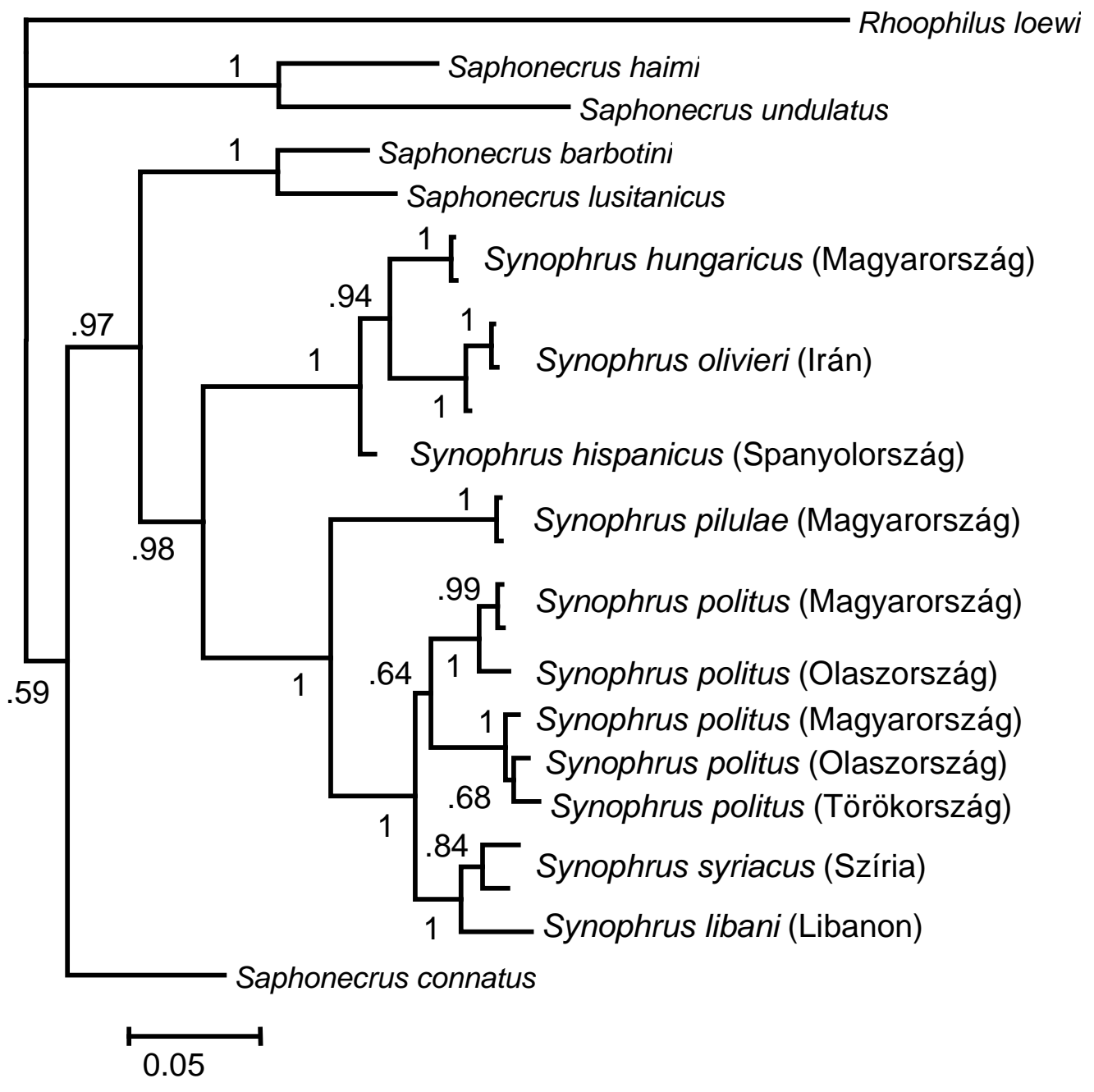

9. ábra A Synophrus, Saphonecrus és Roophilus génuszok 50\% majority-rule konszenzus fája, mely Bayes analízissel, a nem partícionált citokróm oxidáz, a 28S D2 és a 28S D2 gap adatok kombinált analízisével készült. A gyökér pozícióját a Roophilus loewi fajt használva határoztuk meg. Az elágazási pontok felett a posterior valószínüség értékeket tüntettük fel.

A S. libani két szubsztitúcióban tért el a $S$. politusra jellemző haplotípustól. Az iráni $S$. syriacus minták egy bázispárnyi különbséget mutattak attól a haplotípustól, mely az összes szíriai $S$. syriacus, valamint a török, olasz és magyar $S$. politus mintákra jellemző. A S. pilulae minták egy egyedi haplotípussal rendelkeznek. Amint az az egyes filogenetikai fák hasonlósága alapján sejthető volt, a COI, D2 és D2 gap adatok kombinált analízise a COI-hoz hasonló topológiát eredményezett (9. ábra). A COI szekvenciák kodon pozíció szerinti partícionálása nem befolyásolta a kapott fa 
topológiáját.

A fajon belüli szekvencia variabilitást COI-ra a szegregáló pozíciók százalékos arányával becsültük. Ez a $S$. olivieri szekvenciákra $1.4 \%, 2.6 \%$ az iráni és szíriai $S$. syriacus szekvenciákra, melyek között egy gapnyi különbség is volt 28S D2 tekintetében. Általában véve a fajon belüli variabilitás Magyarországon jóval alacsonyabb volt, kevesebb, mint $0.6 \%$ S. pilulae és $S$. hungaricus esetében.

A Synophrus politus leszármazási vonalon belül két alcsoport különíthető el, melyek közötti szekvencia divergencia 2.1\%. Az egyik alcsoportba a török, olasz (Piombino) és egy magyar minta tartozik. A másikba 58 magyar és 8 olasz (Savoria) egyed sorolható, ez utóbbiak szekvenciája teljesen azonos. A magyar minták 1.2\% variabilitást mutattak, de feltehetően ez nem magyarázható a földrajzi elhelyezkedéshez, sem a növényi szervhez köthető mintázattal. Az összes magyarországi mintavételi helyen ugyanazok a haplotípusok domináltak. Azonban a kérdés vizsgálatához a mintavétel nem adekvát, ezért nem is teszteltük. A legtöbb szubsztitúció parszimónia tekintetében nem informatív (8. ábra).

Szekvencia adataink a Saphonecrus fajok két csoportra osztását támogatják (8. ábra, 9. ábra). (i) A Saphonecrus lusticianus és S. barbotini képezi a Synophrus leszármazási vonal testvércsoportját. (ii) A Saphonecrus haimi és S. undulatus alkotja a másik csoportot, melynek a többihez való viszonya a jelen analízisben nem tisztázható, csak úgy, mint a Saphonecrus connatus faj filogenetikai viszonya. Későbbi vizsgálataink (Ács és mtsi, 2010) a fenti két csoport létét megerősítették, azonban a $S$. connatus faj helyzete továbbra is bizonytalan maradt.

\section{Synergus umbraculus}

\section{Szekvencia és haplotípus variabilitás}

A 239 cytb szekvencia alapján 66 különböző haplotípust tudtunk elkülöníteni, ez protein szinten 29 haplotípusnak felel meg (2. táblázat). A vizsgált 697 bázispárnyi szakaszon 119 pozíció volt variábilis, ebből 94 volt parszimónia informatív (9 pozíció 3, további 2 pozíció 4 négy állapottal). A fenti 119 pozícióból 84 (71\%) volt tranzíció. A teljes haplotípus diverzitás 0.916 (szórás $(\mathrm{SD})=0.010$ ), a nukleotid diverzitás 0.036 
( $\mathrm{SD}=0.0018)$ volt. A DNS szinten elkülöníthető 66 haplotípusból 43 (65\%) egyedi volt, vagyis csak egy adott egyedben azonosítottuk, míg az öt leggyakoribb haplotípus a minták 60\%-át (n=144) jellemezte. A nyugat palearktikumi régiók szintjén a haplotípus diverzitás látszólag a mintanagyságnak megfelelően alakult, 40 haplotípust találtunk a Kárpát-medencében, 4-10 haplotípust Iránban, Olaszországban, Törökországban, az ibériai régióban és az Egyesült Királyságban. Az egyes régiókra vonatkozó géndiverzitás értékek 0.500 és 0.852 közé, a nukleotid diverzitás értékek 0.007 és 0.032 tartományba estek (2. táblázat).

Régiók szintjén a haplotípusok földrajzi eloszlása jelentős genetikai differenciációra utal. Olaszország kivételével a haplotípusok több, mint fele egyedi volt egy adott régióra, ezek közül $14(\mathrm{n}=86,36 \%)$ több egyedben, de csak egy régióban volt jelen. 9 haplotípus ( $\mathrm{n}=110,46 \%)$ több régióban is jelen volt, ezek közül egy (ht05) négy régióban, egy (ht04) háromban és hét másik két régióban. Az ibériai régiónak egyetlen másik régióval közös haplotípusa sem volt. Ezzel szemben Olaszország és a Kárpátmedence 6 közös haplotípussal jellemezhető. Törökország és Irán mindössze egy közös haplotípussal rendelkezik. Az Egyesült Királyságban tizenegyböl hét egyedre a gyakori ht05 haplotípus volt jellemző és egy közös haplotípusa (ht09, n=2 az Egyesült Királyságban) volt a szomszédos francia-német régióval.

A Kárpát-medencén belül a géndiverzitás $(\mathrm{h}=0.766-0.943)$ és nukleotid diverzitás ( $\pi=0.020-0.035)$ értékek hasonlóak voltak az egyes régiókban, és viszonylag magasak a Nyugat Palearktikum régióihoz viszonyítva (3. táblázat). Az öt kárpátmedencei régióban ( $\mathrm{n}=146)$ összesen 37 haplotípust találtunk, melyek közül $22(59.5 \%)$ csak egy adott mintára volt jellemző, míg további 6 csak egy területen, de 2-3 mintában volt jelen. A Kárpát-medence számos megosztott haplotípussal rendelkezik mind saját régióit, mind a többi nagyobb régiót figyelembe véve (összesen $\mathrm{n}=110,75.3 \%$ ). A 9 megosztott kárpát-medencei haplotípus közül a leggyakoribb (ht01, n=49) minden kárpát-medencei régióban jelen volt, de sehol máshol a Nyugat Palearktikumban. A kárpát-medencei minták jelentős hányada $(n=58,39.73 \%)$ jellemezhető megosztott haplotípussal, köztük a szintén gyakorinak tekinthető ht04 és ht05 haplotípusokkal $(\mathrm{n}=11)$. A második leggyakoribb haplotípust (ht02, n=33 a Kárpát-medencében) 4 hazai régióban megtaláltuk és 2 példányban Olaszországban is, míg a harmadik leggyakoribb haplotípus (ht03, n=22 a Kárpát-medencében) szintén 4 hazai régióban és nagy számban $(\mathrm{n}=7)$ Törökországban is jelen volt. 


\begin{tabular}{|l|l|l|l|l|l|l|l|l|l|}
\hline & Összes & FG & GR & KM & IM & IR & IT & TL & UK \\
\hline Minta nagyság & 239 & 6 & 4 & 158 & 9 & 18 & 20 & 13 & 11 \\
\hline Mintavételi helyek száma & 73 & 5 & 3 & 21 & 6 & 7 & 17 & 9 & 6 \\
\hline Haplocsoportok száma & 8 & 1 & 1 & 6 & 2 & 2 & 4 & 3 & 2 \\
\hline Haplotípusok száma & 66 & 3 & 2 & 40 & 5 & 10 & 8 & 6 & 4 \\
\hline Egyedi haplotípusok száma & 43 & 1 & 1 & 24 & 3 & 7 & 2 & 3 & 2 \\
\hline Szegregáló pozíciók száma & 119 & 2 & 1 & 100 & 29 & 19 & 67 & 53 & 52 \\
\hline Az összes mutációk száma & 132 & 2 & 1 & 110 & 30 & 19 & 67 & 55 & 52 \\
\hline Haplotípus (gén) diverzitás (SD) & $\begin{array}{l}0.916 \\
(0.010)\end{array}$ & $\begin{array}{l}0.600 \\
(0.215)\end{array}$ & $\begin{array}{l}0.500 \\
(0.265)\end{array}$ & $\begin{array}{l}0.852 \\
(0.020)\end{array}$ & $\begin{array}{l}0.806 \\
(0.120)\end{array}$ & $\begin{array}{l}0.810 \\
(0.093)\end{array}$ & $\begin{array}{l}0.842 \\
(0.060)\end{array}$ & $\begin{array}{l}0.718 \\
(0.128)\end{array}$ & $\begin{array}{l}0.600 \\
(0.154)\end{array}$ \\
\hline Nukleotid diverzitás x100 (SD) & 3.603 & 0.096 & 0.072 \\
$(0.181)$ & $(0.040)$ & $(0.038)$ & $\begin{array}{l}3.182 \\
(0.257)\end{array}$ & $\begin{array}{l}1.706 \\
(0.397)\end{array}$ & $\begin{array}{l}0.436 \\
(0.130)\end{array}$ & $\begin{array}{l}3.236 \\
(0.636)\end{array}$ & $\begin{array}{l}2.056 \\
(0.882)\end{array}$ & $\begin{array}{l}2.400 \\
(1.095)\end{array}$ \\
\hline Páronkénti különbségek átlaga & 25.11 & 0.67 & 0.50 & 22.18 & 11.89 & 3.04 & 22.58 & 14.33 & 16.73 \\
\hline Patrisztikus távolság átlaga x100 & 5.12 & 0.12 & 0.17 & 4.55 & 2.36 & 0.72 & 5.22 & 2.39 & 3.92 \\
\hline
\end{tabular}

2. táblázat A Synergus umbraculus citokróm b szekvenciákra vonatkozó genetikai diverzitás értékek a Nyugat Palearktikum egyes régióira. Rövidítések: "FG" - Franciaország és Németország; "GR” - Görögország; "KM" - Kárpát-medence; "IM" - Ibéria és Marokkó; "IR" - Irán; "IT" - Olaszország; "TL” - Törökorszák és Libanon; "UK” - Egyesült Királyság; "SD” szórás. 


\begin{tabular}{|c|c|c|c|c|c|c|c|c|}
\hline & Összes & Aggtelek & Eger & Gödöllő & Mátra & Mecsek & $\mathrm{A}$ & B \\
\hline Minta nagyság & 146 & 27 & 15 & 8 & 69 & 27 & 138 & 123 \\
\hline Mintavételi helyek száma & 10 & 1 & 1 & 1 & 4 & 3 & 9 & 8 \\
\hline Haplocsoportok száma & 6 & 3 & 3 & 4 & 5 & 3 & 5 & 5 \\
\hline Haplotípusok száma & 37 & 9 & 10 & 5 & 20 & 12 & 35 & 31 \\
\hline Egyedi haplotípusok száma & 22 & 4 & 3 & 1 & 10 & 4 & 21 & 17 \\
\hline Szegregáló pozíciók száma & 97 & 76 & 74 & 65 & 85 & 51 & 92 & 90 \\
\hline Az összes mutációk száma & 107 & 82 & 80 & 65 & 94 & 56 & 102 & 100 \\
\hline Haplotípus (gén) diverzitás (SD) & $\begin{array}{l}0.847 \\
(0.022)\end{array}$ & $\begin{array}{l}0.766 \\
(0.068)\end{array}$ & $\begin{array}{l}0.943 \\
(0.040)\end{array}$ & $\begin{array}{l}0.857 \\
(0.108)\end{array}$ & $\begin{array}{l}0.845 \\
(0.030)\end{array}$ & $\begin{array}{l}0.855 \\
(0.048)\end{array}$ & $\begin{array}{l}0.844 \\
(0.022)\end{array}$ & $\begin{array}{l}0.831 \\
(0.025)\end{array}$ \\
\hline Nukleotid diverzitás x100 (SD) & $\begin{array}{l}3.075 \\
(0.264)\end{array}$ & $\begin{array}{l}3.082 \\
(0.715)\end{array}$ & $\begin{array}{l}3.462 \\
(0.777)\end{array}$ & $\begin{array}{l}3.438 \\
(0.918)\end{array}$ & $\begin{array}{l}3.323 \\
(0.347)\end{array}$ & $\begin{array}{l}2.009 \\
(0.541)\end{array}$ & $\begin{array}{l}3.044 \\
(0.273)\end{array}$ & $\begin{array}{l}3.013 \\
(0.292)\end{array}$ \\
\hline Páronkénti különbségek átlaga & 21.43 & 27.15 & 26.70 & 20.28 & 23.87 & 26.63 & 21.21 & 21.00 \\
\hline Patrisztikus távolság átlaga x100 & 4.32 & 5.58 & 5.59 & 4.21 & 4.81 & 5.44 & 4.25 & 4.23 \\
\hline
\end{tabular}

3. táblázat A Synergus umbraculus citokróm b szekvenciákra vonatkozó genetikai diverzitás értékek a Kárpát-medence egyes régióira. "A"-val jelöltük azt az adathalmazt, mely csak az Aggtelek, Eger, Mátra és Mecsek régiókat foglalja magában. "B”-vel az Aggtelek, Mátra és Mecsek régiókat tartalmazó adathalmazt jelöltük. "SD" - szórás. 


\section{Filogenetikai elemzés és a haplocsoportok jellemzése}

Elemzésünk 8 fő cytb haplotípus csoportot (haplocsoportot, H1-H8, 10. ábra, 4. táblázat) különített el, melyek támogatottsága magas (posteriori valószínüség, pp>0.99) a filogenetikai rekonstrukcióban. Az egyes mintákra és haplotípusokra vonatkozó haplocsoport szerinti besorolás az 1. függelékben található. A haplocsoportok közötti kapcsolatok magas megbízhatósággal rekonstruálhatóak (pp>0.91) egy kivétellel: a H3, H7 és (H1, H2, H3) csoportok közötti viszony bizonytalan ( $\mathrm{pp}=0.43)$. A fa topológiája alapján 3 csoport különíthető el a divergencia sorrendje tekintetében, melyek a föbb refúgiumokkal hozhatók összefüggésbe. Az első csoportot a H6 haplocsoport alkotja, mely a legkorábban elkülönülő ág. Mindössze 4 haplotípus tartozik ide, azonban számos helyről előkerültek ( $n=27$, 4. táblázat, 7. ábra) Olaszország, a Kárpát-medence és Nyugat-Európa területén; az összes francia és német minta ebbe a csoportba tartozik. A második csoport egy Balkán-Kárpát-medence leszármazási vonalnak tekinthető, melyet a H4 (n=3, 1 haplotípus hazánkban) és H5 (n=38) haplocsoportok alkotnak. A H5 haplocsoportba tartozik az a ht03 haplotípus is, mely mind Törökországban, mind a Kárpát-medencében gyakori. A harmadik csoportot pedig az összes többi haplocsoport alkotja.

A H3 és H7, két, vélhetőleg afro-ibériai eredetü csoport. A H3 haplocsoportba (n=7) észak-spanyol (ht51), észak-afrikai (Marokkó, ht50), kárpát-medencei (ht16, Gödöllö, n=2), valamint olasz és kárpát-medencei (ht13, n=3) haplotípusok tartoznak. A H7 haplocsoport ( $n=7)$ az ibériai régióban endemikus, csak Ibéria nyugati és déli részén és Marokkóban találtuk meg. A H3, H7 és a H1-H2-H8 csoportok közötti leszármazási viszony bizonytalan.

A H1-H2-H8 csoporton belül (n=157) a H2 leszármazási vonal (n=33) az ibériai és a francia-német régión kívül minden más területen megtalálható és magába foglalja a már említett ht05 haplotípust, ami Olaszországban a legjellemzőbb haplotípus. Ezzel szemben a H8 (n=18) haplocsoport föként Irán és Törökország (1 minta) területén fordul elő. A H1 leszármazási vonal $(n=106)$ a Kárpát-medencében fordul elő tömegesen, valamint 3 mintában Olaszországban is. A H1 haplocsoportba tartozik a két leggyakoribb haplotípus (ht01, ht02). 


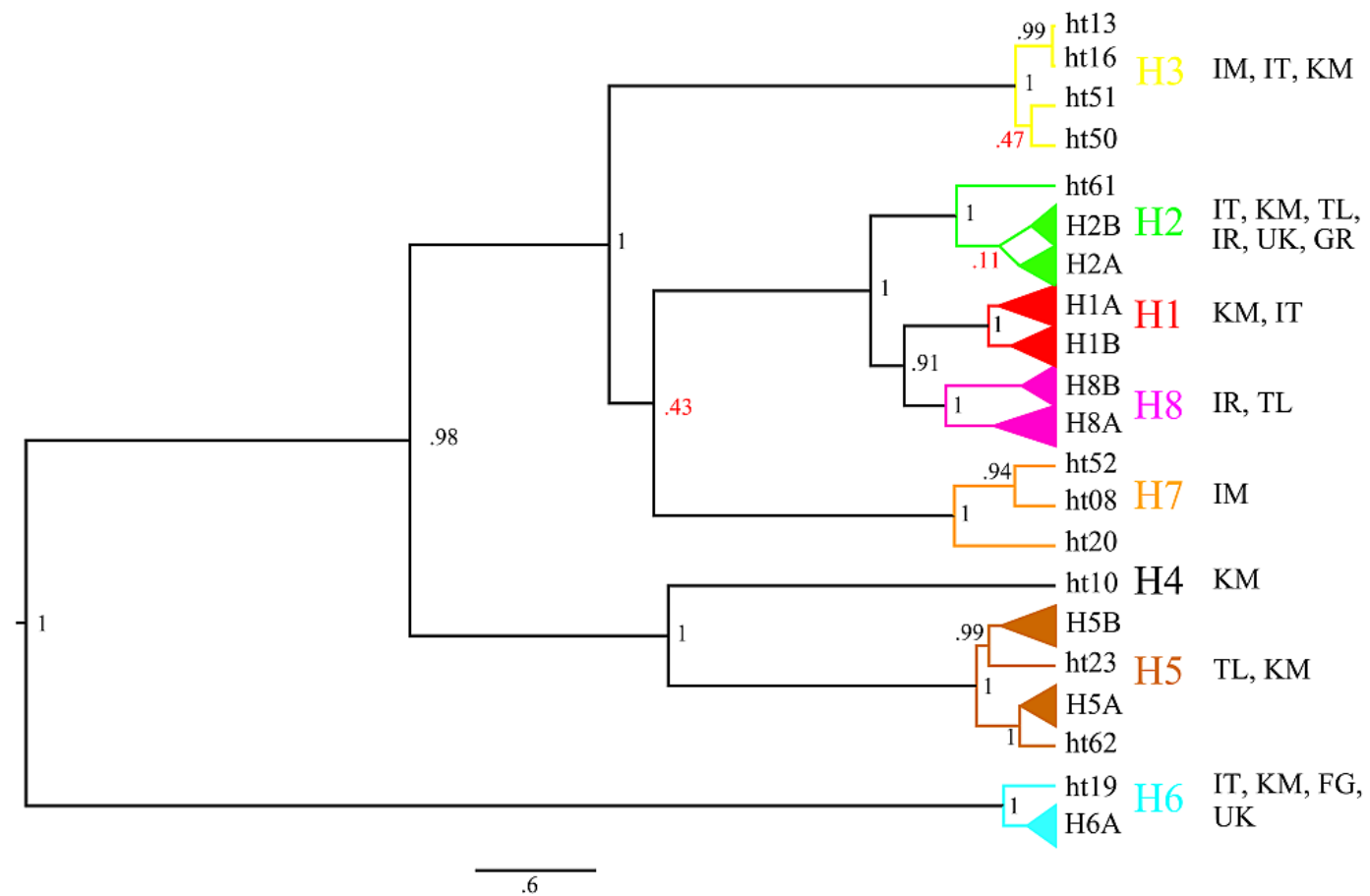

10. ábra A Synergus umbraculus citokróm b haplotípusok ultrametrikus filogenetikai fája. Az analízist a BEAST szoftverrel végeztük, kodon partícionált GTR+I+G modellt és molekuláris órát (strict clock) használva. Az elágazási pontok felett a posterior valószínűség értékeket tüntettük fel; a 0.90-nél kisebb értékeket pirossal kiemeltük. A lépték az időt mutatja millió években Brower (1994) becslését alapul véve $(1.15 \%$ szekvencia divergencia/millió év/leszármazási vonal). A nagyszámú haplotípust tartalmazó alcsoportokat egyszerüsítve jelöltük. Ugyanazt a színkódolást használtuk, mint a 7. ábránál, a haplocsoportok nevei mellett az elterjedést is feltüntettük. Rövidítések: "FG" - Franciaország és Németország; "GR" - Görögország; "KM" Kárpát-medence; "IM" - Ibéria és Marokkó; "IR" - Irán; "IT" - Olaszország; "TL" Törökorszák és Libanon; "UK” - Egyesült Királyság.

Az afro-ibériai H7 és az iráni H8 csoportok nukleotid diverzitása (4. táblázat) magasabb, mint a jóval elterjedtebb H6 és H2 csoportoké. A bazálisan elkülönült H6 jellemezhető a legalacsonyabb diverzitással.

A filogenetikai elemzés alapján elmondhatjuk, hogy míg az afro-ibériai H7 és az iráni H8 endemikus haplocsoportok, addig más régiókban számos széles elterjedésü haplocsoport is megtalálható (Kárpát-medence: H1-6, Olaszország: H1-3, H6), amely a magas régió diverzitást magyarázhatja (2. táblázat). Olaszország és a Kárpát-medence 4 különböző közös haplocsoporttal rendelkezik, Törökország és a Kárpát-medence közös H5 haplotípusokkal, Törökország és Irán pedig egy közös H2 haplotípussal jellemezhetö. 


\begin{tabular}{|c|c|c|c|c|c|c|c|c|c|}
\hline & Összes & H1 & $\mathrm{H} 2$ & $\mathrm{H} 3$ & $\mathrm{H} 4$ & H5 & H6 & $\mathrm{H} 7$ & $\mathrm{H} 8$ \\
\hline Minta nagyság & 239 & 106 & 33 & 7 & 3 & 38 & 27 & 7 & 18 \\
\hline \multirow[t]{2}{*}{ Régiók száma } & 8 & 2 & 6 & 3 & 1 & 2 & 4 & 1 & 2 \\
\hline & & KM, IT & $\begin{array}{r}\text { IT, KM, } \\
\text { TL, IR, } \\
\text { UK, GR }\end{array}$ & $\begin{array}{r}\text { IM, IT, } \\
\text { KM }\end{array}$ & KM & $\mathrm{TL}, \mathrm{KM}$ & $\begin{array}{l}\text { IT, KM, } \\
\text { FG, UK }\end{array}$ & IM & IR, TL \\
\hline Haplotípusok száma & 66 & 21 & 11 & 4 & 1 & 12 & 4 & 3 & 10 \\
\hline Haplotípus (gén) diverzitás (SD) & $\begin{array}{r}0.916 \\
(0.010)\end{array}$ & $\begin{array}{r}0.693 \\
(0.034)\end{array}$ & $\begin{array}{r}0.663 \\
(0.090)\end{array}$ & $\begin{array}{r}0.810 \\
(0.130)\end{array}$ & 0 & $\begin{array}{r}0.661 \\
(0.086)\end{array}$ & $\begin{array}{r}0.390 \\
(0.112)\end{array}$ & $\begin{array}{r}0.667 \\
(0.160)\end{array}$ & $\begin{array}{r}0.810 \\
(0.093)\end{array}$ \\
\hline Szeggregáló pozíciók száma & 119 & 20 & 11 & 5 & 0 & 14 & 4 & 13 & 12 \\
\hline Az összes mutációk száma & 132 & 21 & 11 & 5 & 0 & 15 & 4 & 13 & 12 \\
\hline Nukleotid diverzitás x100 (SD) & $\begin{array}{r}3.603 \\
(0.181)\end{array}$ & $\begin{array}{r}0.135 \\
(0.013)\end{array}$ & $\begin{array}{r}0.160 \\
(0.033)\end{array}$ & $\begin{array}{r}0.287 \\
(0.091)\end{array}$ & 0 & $\begin{array}{r}0.498 \\
(0.074)\end{array}$ & $\begin{array}{r}0.081 \\
(0.028)\end{array}$ & $\begin{array}{r}0.806 \\
(0.209)\end{array}$ & $\begin{array}{r}0.371 \\
(0.085)\end{array}$ \\
\hline Páronkénti különbségek átlaga & 25.11 & 0.94 & 1.12 & 2 & 0 & 3.47 & 0.56 & 5.62 & 2.59 \\
\hline Patrisztikus távolság átlaga x 100 & 5.12 & 0.46 & 0.35 & 0.24 & 0 & 0.46 & 0.12 & 0.64 & 0.61 \\
\hline
\end{tabular}

4. táblázat A Synergus umbraculus citokróm b haplocsoportok genetikai diverzitása. Rövidítések: "FG" - Franciaország és Németország; "GR" - Görögország; "KM" - Kárpát-medence; "IM" - Ibéria és Marokkó; "IR” - Irán; "IT” - Olaszország; “TL” - Törökorszák és Libanon; "UK" Egyesült Királyság; "SD” szórás. 


\section{Statisztikus parszimónia hálózat}

A három fiatalabb divergenciájú haplocsoport $\left(\mathrm{H} 1, \mathrm{H} 2, \mathrm{H} 8, \mathrm{n}_{\ddot{o ̈ s s z}}=157\right)$ haplotípusait és ezek rokonsági viszonyait egy statisztikus parszimónia hálózattal is elemeztük (11. ábra). E három haplocsoportra vonatkozó cytb szekvenciákban összesen 47 variábilis pozíciót találtunk, melyek $80 \%$ tranzíció, és csak egyben volt többszörös szubsztitúció megfigyelhető, így a parszimónia feltételei feltehetően nem sérülnek számottevő mértékben. A hálózat a H1, H2 és H8 haplocsoportok differenciációját több elméleti (vagyis nem mintázott) haplotípuson keresztül valószínüsíti. A haplocsoportok közötti rokonsági viszonyok a filogenetikai rekonstrukcióhoz hasonlóak (10. ábra). A H1 csoportot két alcsoportra oszthatjuk (H1A és H1B), melyeket egy mutációs lépés választ el egymástól. A H1A alcsoport központi haplotípusa egyben a leggyakoribb haplotípus (ht01) is, a H1B központi haplotípusa a második leggyakoribb ht02. Mindkét központi haplotípusból általában egy szubsztitúció távolságra találhatóak a további haplotípusok. Ez alól csak a ht29 képez kivételt, mely 3 lépésnyire van a ht01-től. Az összes H1 haplotípus jelen van a Kárpát-medencében és a két Olaszországban kimutatott $\mathrm{H} 1$ haplotípus is: a ht02, mely két mintát és a ht14, mely egy mintát jellemez.

A haplotípus hálózat alapján a H1 haplocsoport közelebb van az iráni H8-hoz, mint a H2-höz. A H8 csoportra komplexebb mintázat és nagyobb szekvencia divergencia jellemző, ami a filogenetikai elemzésen is látható (10. ábra).

Hasonlóan a H1 haplocsoporthoz, a H2-re is jellemző két alcsoport (H2A és H2B) és egy-egy központi haplotípus jelenléte (ht05, ht07), melyek egymástól egyetlen mutációs lépésre vannak, és belölük elágazva egy vagy néhány lépésre található az alcsoport többi haplotípusa. A ht05 (H2A) a legelterjedtebb haplotípus valamennyi közül (Egyesült Királyság, Kárpát-medence, Olaszország, Görögország), míg a ht07 (H2B) megosztott a Kárpát-medence és Olaszország között. A legtöbb haplotípus a ht05-ből származtatható, és szinte az egész Nyugat Palearktikumban megtalálható: a ht66 és ht65 az Egyesült Királyságban, a ht25 Görögországban, a ht21 Törökországban és Iránban, a ht48 és ht49 a Kárpát-medencében. Ezzel szemben a H2B alcsoport valamennyi tagja kizárólag Olaszországban és a Kárpát-medencében fordul elő: ht07 mindkét régióban, a ht41 hazánkban, a ht60 és ht61 Olaszországban. Filogenetika alapján a H1-H2-H8 csoportok közül elöbb a H2 csoport különült el. 


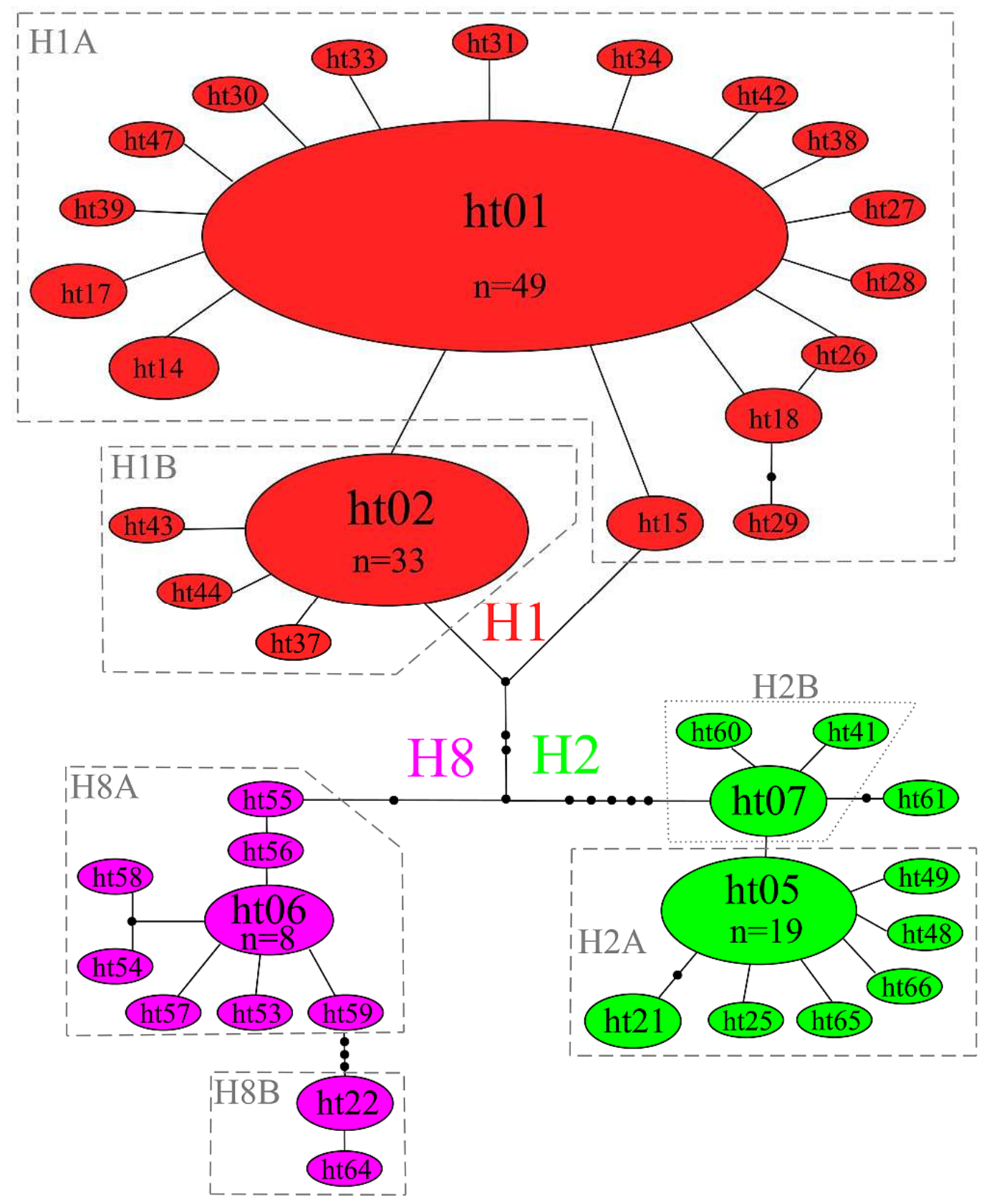

11. ábra A Synergus umbraculus citokróm b haplotípusok statisztikus parszimónia hálózata a H1, H8 és H2 haplocsoportokra. A vonalakon levő fekete pontok a szoftver által becsült, de nem mintázott köztes haplotípusokat jelölik. Az ellipszisek mérete az adott haplotípus gyakoriságára utal. A szaggatott vonalakkal körülhatároltak olyan alcsoportokat jelölnek, melyek meglétét a filogenetikai analízis is támogatja (10. ábra). Ugyanazt a színkódolást használtuk, mint a 7. és 10. ábráknál. 


\section{Genetikai differenciáció}

A Nyugat Palearktikum régiói közötti szignifikáns fixációs index $\Phi_{\mathrm{ST}}=0.200$ $(\mathrm{p}<0.01)$ patrisztikus távolsággal számolva, míg eltérő pozíciók száma alapján $\Phi_{\mathrm{ST}}=0.246(\mathrm{p}<0.01)$. Ezek az értékek a genetikai variabilitás fent elemzett térbeli differenciációját igazolják. Ugyanakkor a variabilitás jelentős része - 80\% patrisztikus távolság alapján, $75.4 \%$ eltérő pozíciók száma alapján - az egyes régiókon belüli különbségeknek köszönhetö. A régiók közötti páronkénti $\Phi_{\mathrm{ST}}$ értékek igen hasonlóak voltak függetlenül a számoláshoz használt távolság módszertől, ezért csak azokat tárgyaljuk, melyeket az eltérő pozíciók száma alapján számoltunk (5. táblázat). A legmagasabb páronkénti értékeket az Ibéria és Törökország összehasonlítása $\left(\Phi_{\mathrm{ST}}=0.653, \mathrm{p}<0.01\right)$, az Ibéria és Irán $\left(\Phi_{\mathrm{ST}}=0.888, \mathrm{p}<0.01\right)$, valamint az Anatóliai Diagonál két oldala közti Törökország és Irán $\left(\Phi_{\mathrm{ST}}=0.839, \mathrm{p}<0.01\right)$ összehasonlítás alapján kaptunk. Ezzel szemben viszonylag alacsony értékeket kaptunk a Kárpátmedence, Olaszország, Egyesült Királyság régiók bármely kombinációjára $\left(\Phi_{\mathrm{ST}}<0.086\right.$, $\mathrm{p}=0.032-0.67)$.

\begin{tabular}{|l|l|l|l|l|l|l|}
\hline & KM & IM & IR & IT & TL & UK \\
\hline KM & & 0.261 & 0.169 & 0.069 & 0.380 & 0.086 \\
\hline IM & 0.244 & & 0.888 & 0.361 & 0.653 & 0.462 \\
\hline IR & 0.115 & 0.807 & & 0.295 & 0.839 & 0.364 \\
\hline IT & 0.051 & 0.249 & 0.198 & & 0.510 & $\approx 0.0$ \\
\hline TL & 0.341 & 0.728 & 0.845 & 0.454 & & 0.573 \\
\hline UK & 0.054 & 0.335 & 0.226 & $\approx 0.0$ & 0.530 & \\
\hline
\end{tabular}

5. táblázat AMOVA eredmények a Nyugat Palearktikum régióira. Az átló feletti páronkénti $\Phi_{\mathrm{ST}}$ értékeket eltérő pozíciók száma alapján, míg az átló alattiakat patrisztikus távolság alapján számoltuk. A p=0.05 szignifikancia szint mellett nem szignifikáns $\Phi_{\mathrm{ST}}$ értékeket dőlt betüvel jelöltük. Rövidítések: "FG" - Franciaország és Németország; "GR" - Görögország; "KM" - Kárpát-medence; "IM" - Ibéria és Marokkó; "IR" - Irán; "IT" - Olaszország; "TL" - Törökorszák és Libanon; "UK" Egyesült Királyság.

A genetikai variabilitás térbeli differenciációja jóval kevésbé volt kifejezett a Kárpát-medencén belül, mint a Nyugat Palearktikum egyes régiói között. A Kárpátmedence mind az 5, vagy csak 4 (Gödöllő nélkül), vagy csak 3 (Gödöllő és Eger nélkül) régiója között számolt páronkénti $\Phi_{\mathrm{ST}}$ értékek minden esetben alacsonyak, a különbségek nem szignifikánsak $\left(\Phi_{\mathrm{ST}}<0.026, \mathrm{p}=0.097-0.373\right)$. A Mecsek régió mutatta a legnagyobb differenciációt a páronkénti összehasonlításokban, amint ez földrajzi 
helyzete alapján várható is (6. táblázat).

\begin{tabular}{|l|l|l|l|l|l|l|l|l|l|}
\hline & \multicolumn{4}{|c|}{ Eltérő pozíciók száma } & \multicolumn{5}{c|}{ Patrisztikus távolság } \\
\hline & $\mathrm{R}^{2}$ & Variancia\% & $\Phi_{\mathrm{ST}}$ & $\mathrm{p}$ & & $\mathrm{R}^{2}$ & Variancia\% & $\Phi_{\mathrm{ST}}$ & $\mathrm{p}$ \\
\hline $\begin{array}{l}\text { Aggtelek vs } \\
\text { Mátra }\end{array}$ & 0.011 & 0.045 & 0.000 & 0.340 & & 0.015 & 1.031 & 0.010 & 0.234 \\
\hline $\begin{array}{l}\text { Aggtelek vs } \\
\text { Mecsek }\end{array}$ & 0.027 & 1.659 & 0.017 & 0.304 & 0.046 & 5.293 & 0.053 & 0.089 \\
\hline $\begin{array}{l}\text { Mátra vs } \\
\text { Mecsek }\end{array}$ & 0.025 & 3.566 & 0.036 & 0.094 & 0.025 & 3.407 & 0.034 & 0.092 \\
\hline
\end{tabular}

6. táblázat AMOVA eredmények a Kárpát-medence régióira eltérő pozíciók száma és patrisztikus távolság alapján. A variancia (\%) a csoportok közötti variancia százalékos aránya a teljes (csoportok közötti és csoporton belüli) varianciához képest.

\section{Gazda szerinti genetikai differenciáció}

A Mátra régió mintáin elvégzett elemzés nem mutatott szignifikáns eltérést a négy leggyakoribb rovar gazda gubacsából kinevelt Synergus umbraculus egyedek között. A teljes variabilitás mindössze 2-5\%-a köthető a gazdák közti különbségekhez (eltérő pozíciók száma alapján $\Phi_{\mathrm{ST}}=0.022$, p $>0.1$, patrisztikus távolság alapján $\Phi_{\mathrm{ST}}=0.051, \mathrm{p}>0.1$, 7. táblázat $)$.

\begin{tabular}{|l|c|c|c|c|c|c|}
\hline & \multicolumn{3}{|c|}{ Eltérő pozíciók száma } & \multicolumn{3}{c|}{ Patrisztikus távolság } \\
\hline & Df & $\mathrm{R}^{2}$ & Variancia (\%) & Df & $\mathrm{R}^{2}$ & Variancia (\%) \\
\hline Gazda & 3 & 0.071 & 2.24 & 3 & 0.092 & 5.096 \\
\hline Maradék & 51 & 0.929 & 97.76 & 51 & 0.908 & 94.903 \\
\hline Összes & 54 & & & 54 & & \multicolumn{3}{c|}{ F: $1.716, \mathrm{p}=0.114, \Phi_{\text {ST }}: 0.051$} \\
\hline
\end{tabular}

7. táblázat A mátrai gubacsdarázs gazdákra vonatkozó AMOVA eredmények. Mind az eltérő pozíciók száma, mind a patrisztikus távolság alapján kapott eredményeket feltüntettük. A variancia (\%) a csoportok közötti variancia százalékos aránya a teljes (csoportok közötti és csoporton belüli) varianciához képest. 


\section{Diszkusszió}

\section{Synophrus}

\section{Filogenetika}

A Cynipidae csoportban a morfológiai jellemzőkön és molekuláris adatokon alapuló filogenetikai rendszer számos ponton eltér (Nylander és mtsi, 2004a, b; Ács és mtsi, 2007). A nagyobb változatosságot mutató szekvenciák gyakran nagyobb felbontást eredményeznek, a nem kongruens eredmények a kérdéses taxon revízióját vonhatják maguk után. A Nyugat Palearktikumban korábban 3 fajt különítettek el a Synophrus

génuszban. Új minták, molekuláris filogenetikai elemzésünk és a diagnosztikus morfológiai karakterek ezt követő újraértékelése 4 további tudományra új faj leírását eredményezték: Synophrus hungaricus Melika és Mikó, 2009, S. libani Melika és Pujade-Villar, 2009, S. syriacus Melika, 2009 és S. hispanicus Pujade-Villar, 2009. Ennek megfelelően hazánk faunája egy inkvilin fajjal bővült (Synophrus hungaricus), amely ezidáig csak Magyarországról ismert.

A molekuláris filogenetika nem csak új csoportokra hívta fel a figyelmet, a leszármazási kapcsolatok - amelyek már a morfológiai elemzések alapján is vitatottak voltak - is átértékelődtek. Eredményeink alátámasztják azt a feltevést, miszerint minden Synophrus faj, valamint a Saphonecrus barbotini Pujade-Villar és Nieves-Aldrey, 1985 és a Saphonecrus lusitanicus Tavares, 1902 monofiletikus egységet alkot. A Saphonecrus, mint önálló monofiletikus egység további fenntartását azonban sem a morfológiai, sem a szekvencia adatok nem támogatják. Ennek megfelelően két Saphonecrus faj, a Saphonecrus lusitanicus és a Saphonecrus barbotini feltehetően átsorolásra kerül a Synophrus génuszba.

Ács és mtsi (2010) eredményei ugyanezt a csoportosítást támogatják. Mindhárom általuk vizsgált lokusz (cytb, COI és 28S D2) alapján a Synophrus génusz monofiletikus, a Saphonecrus fajok pedig három csoportra oszlanak: (i) S. connatus, (ii) S. barbotini és lusitanicus és (iii) S. undulatus, S. haimi és S. irani. E három csoport, valamint a Synophrus fajok filogenetikai kapcsolata azonban Ács és mtsi (2010) alapján sem egyértelmü, mivel a különböző génfák erre vonatkozólag nem teljesen kongruensek. Például a $S$. connatus helyzete is bizonytalan. A kérdés 
megválaszolásához több független morfológiai és molekuláris információra lenne szükség. A nevezéktant érintő változtatások az eddig ismert összes Saphonecrus faj (Abe és mtsi, 2007) vizsgálatával együtt folyamatban vannak (Melika, személyes közlés).

A Synophrus génusz molekuláris filogenetikai eredményeink alapján két leszármazási vonalra osztható: (i) S. hispanicus - hungaricus - olivieri, valamint (ii) $S$. pilulae - politus - libani - syriacus. Molekuláris adatok alapján az első leszármazási vonalhoz sorolható az egyetlen algériai minta is (8. ábra), mely paratölgyröl (Quercus suber) származik. Ebben a csoportban jól elkülönül Irán (S. olivieri), Közép-Európa ( $S$. hungaricus) és Ibéria (S. hispanicus), illetve a Synophrus hispanicus és a S. olivieri ibériai és iráni fajpárnak tekinthető. A második leszármazási vonalban is felismerhető földrajzi mintázat a fajok elterjedését illetően. A S. pilulae Közép Európára jellemző, míg e faj testvércsoportját alkotó leszármazási vonalba iráni/szír, libanoni és török/közép-európai fajok tartoznak. A S. syriacus (Irán és Szíria) és S. libani (Libanon) monofiletikus egységet képez, amely magas támogatottsággal elkülönül a török/középeurópai S. politus-tól.

A S. politus COI és 28S D2 adatok alapján is két alcsoportra osztható, az egyik klád török, olasz és magyar mintákat is tartalmaz, a másikba tartozik a magyar minták többsége és azonos haplotípussal jellemezhető 8 olasz minta. Az alcsoportok elterjedésével összefüggő filogeográfiai mintázat részletes elemzése azonban további vizsgálatot igényel. A tagoltság okát kereshetjük például a földrajzi távolságban (isolation by distance), és/vagy a gazdák közötti különbségekben, beleértve a tölgyfajt és a gazda darazsat is (lásd alább). Eredményeink azt sugallják, hogy egyedül a növényi gazda különbséggel nem magyarázható a genetikai differenciáció, mivel Magyarországon csak a csertölgy áll rendelkezésre gazdaként, mégis jelen van mindkét alcsoport. E két alcsoport jelenléte hazánkban arra utal, hogy a Kárpát-medence Synophrus politus populációja mind egy feltételezett appennini, mind egy balkáni refúgiummal összefüggésbe hozható. Ehhez hasonló filogeográfiai mintázat jellemző például az Andricus quercustozae (Rokas és mtsi, 2003) és az Andricus coriarius (Challis és mtsi, 2007) gubacsképzőkre, de ezt kaptuk a Synergus umbraculus-ra is, ami arra utalhat, hogy a Pleisztocén jégkorszakok az egész tölgyhöz kötödő gubacsdarázs faunára hasonló hatással lehettek. 


\section{Gubacs alak és elhelyezkedés}

Sokféle formájú és elhelyezkedésủ gubacsból neveltünk ki Synophrus egyedeket (5. ábra). Annak ellenére, hogy sok a megválaszolatlan kérdés a Synophrus génusz gazdanövény kapcsolatait illetően, néhány dolog tisztázódni látszik. Bizonyos alakú gubacsok egyértelmüen kapcsolhatóak egyes szekvencia alapon elkülöníthető leszármazási sorokhoz, amiből arra következtethetünk, hogy a gubacs morfológia az ide sorolható fajok kiterjesztett fenotípusának tekinthető (Stone és Cook, 1998), nem a gubacsdarázs gazda jellemzőjének. A gubacs morfológia ilyen mérvü módosítása a tölgygubacs inkvilinek körében egyedülálló.

Két alapvetően eltérő gubacsforma különíthető el a Synophrus génuszban. Az első típus a S. hispanicus - hungaricus - olivieri csoportra jellemző szabálytalan formájú duzzanat fiatal hajtásokon, ágakon. Ezen a csoporton belül a $S$. olivieri többkamrás gubacsa közelebbi rokonságban van a $S$. hungaricus hajtás-gubacsával, mint a $S$. hispanicus egykamrás, gömbszerü gubacsával. A második gubacstípus a $S$. pilulae - politus - syriacus csoportra jellemző többnyire szabályosan gömbszerü rügygubacs. Nagyon ritkán $S$. politus egyedek a levélnyélen, vagy a levél föéren képződött gubacsokból is kinevelhetőek. Mivel a gubacs lokalizációját a gubacsot indukáló nőstény darázs peterakási preferenciája határozza meg, a S. politus-ra jellemző ilyenfajta diverzitás arra utalhat, hogy a $S$. politus több gubacsindukáló darázs fajt is támad.

\section{Synergus umbraculus}

\section{Filogeográfia}

A genetikai diverzitásbeli mintázatok hasonlósága a gubacs közösség tagjai között

A Synergus umbraculus fajra kapott eredményeink egy mitokondriális gén szekvencián alapulnak, amelyről feltételezzük, hogy a populációk kapcsolatait, jellemzőit tükrözi. A hagyományos filogeográfia logikáját követtük (Avise, 2000), azonban a következtetéseket óvatosan kell kezelni - ahogy számos egyéb, 
mitokondriális szekvenciákon alapuló vizsgálat eredményét is (pl. Hayward és Stone, 2006; Ursenbacher és mtsi, 2006). Adatsorunk kifejezett genetikai struktúrára utal a Nyugat Pakearktikumra vonatkozólag, egyes régiók saját, a régióra specifikus leszármazási vonalakkal jellemezhetőek (Irán és Ibéria). A legnagyobb diverzitást a Kárpát-medencében találtuk, ami részben a mintázás sajátságainak is köszönhető. A Kárpát-medence jelentős diverzitásának alapvető oka a különböző leszármazási sorok jelenléte. Közös haplotípusok jelenléte és a páronkénti $\Phi_{\mathrm{ST}}$ értékek Olaszország és a Kárpát-medence szoros kapcsolatára utalnak. Ennek oka lehet recens diszperzió, vagy az ősi polimorfizmus jelenleg is zajló rendeződése. Kevésbé szoros kapcsolatot mutattunk ki a Kárpát-medence és Törökország között, ezzel szemben erősen elkülönül Ibéria Közép-Európától (Olaszország, Kárpát-medence). A H3 és H7 haplocsoportokba mindössze 3 nem ibériai minta sorolható, ezek Olaszországból és a Kárpát-medencéből kerültek elő. Mindezek a sajátos mintázatok párhuzamba állíthatóak a gubacs közösség más tagjainál tapasztaltakkal. Például az Andricus és Biorhiza gubacsindukálók (Rokas és mtsi, 2001, 2003; Stone és mtsi, 2001, 2007; Challis és mtsi, 2007), a Cecidostiba (Lohse és mtsi, 2010) és Megastigmus (Nicholls és mtsi, 2010a, b) parazitoid darazsak hasonló biogeográfiai és diverzitás mintázatot mutatnak. Ezen kívül a $S$. umbraculus az Andricus quercustozae és az A. caputmedusae gubacsdarazsakkal is mutat hasonlóságot az Anatóliai Diagonált érintő erős elkülönülés tekintetében (Rokas és mtsi, 2003, Mutun, 2010a, b), amely számos más fajra is ismert (Ekim és Guner, 1986; Kaya és Raynal, 2001). A S. umbraculus esetében a Kárpát-medencében a genetikai diverzitás homogenitását tapasztaltuk, ami az Andricus quercuscalicis gubacsindukáló darázsra is jellemző (Stone és Sunnucks, 1993).

Bizonyos sajátságok tekintetében a $S$. umbraculus eltér a gubacsközösség más részletesen elemzett tagjaitól. Az eddig megvizsgált Andricus gubacsdarazsak és a Megastigmus dorsalis parazitoid esetén az iráni és török mintákra bazális divergencia és magas szekvencia diverzitás jellemző. Kalibrált molekuláris óra alapján valószínüsíthető, hogy a keleti, Irán-Törökország régió lehetett a Pleisztocén előtti és a jégkorszakok utáni populáció kiterjedések forrása, melyek révén Európa északibb területei újra benépesültek (Rokas és mtsi, 2003; Challis és mtsi, 2007; Stone és mtsi, 2007; Nicholls és mtsi, 2010b). Ez a hipotézis a gubacsdarazsak körében az "Out of Anatolia” hipotézisként ismert (“anatóliai eredet” hipotézise), ami az Irán-Törökország régiót jelöli meg a gubacsdarázs leszármazási vonalak diverzifikációs központjaként 
(Stone és mtsi, 2009). S. umbraculus esetében ez a mintázat csak részben ismétlődik meg, mivel a bazális divergenciájú haplocsoportok - H6 (Olaszország és a Kárpátmedence), H5 (Kárpát-medence és Törökország), H4 (Kárpát-medence) - középeurópai és török mintákat foglalnak magukban, de a török mintákat is tartalmazó H5 csak későbbi divergencia következménye (10. ábra). A divergencia sorrendje szerint ezeket követik az ibériai/közép-európai (H3) és ibériai (H7) haplocsoportok, majd a H2, mely az első, amelybe (egyetlen) iráni minta is tartozik. Végül a H1 és H8 haplocsoportok különülnek el egymástól, utóbbiba sorolható az összes többi iráni minta.

\section{A Kárpát-medence genetikai diverzitása}

Eredményeink alapján elmondható, hogy a Kárpát-medence kiemelkedő fontosságú terület a genetikai diverzitás szempontjából. A Nyugat Palearktikumban kimutatott 8 haplocsoport közül 6 megtalálható itt, melyek között endemikusak és széles elterjedésủek is vannak. Csak az Ibériára jellemző H7 és az iráni H8 hiányzik innen. Ennek a kiemelkedő diverzitásnak különböző okai lehetnek. Egyrészt lehetséges, hogy számos más fajhoz hasonlóan a Kárpát-medence egy keveredési zóna (Hewitt, 1999; Comps és mtsi, 2001), melyet az utolsó jégkorszakot követően több refúgiumból is kolonizáltak populációk Olaszország, a Balkán illetve Törökország felől. Másrészt az is elképzelhető, hogy e régió refúgiumnak is tekinthető a vizsgált fajra nézve, ahogy az más fajokkal kapcsolatban ismert (Deffontaine és mtsi, 2005; Ursenbacher és mtsi, 2006; Provan és Bennett, 2008). Fosszilis pollenelemzések arra utalnak, hogy lombhullató fák is túlélhették az utolsó glaciális maximumot a Kárpát-medencében, kedvező mikroklímájú, déli lejtőkön (Willis és mtsi, 2000; Willis és van Andel, 2004). A gubacsdarázs populációk az ilyen erdőkben vagy a közeli Balkánon túlélhettek, ahonnan igen gyorsan újra benépesíthették a területet a melegebb interglaciálisok ideje alatt. Ezt a feltevést látszik alátámasztani a Kárpát-medencére jellemző H1 haplocsoport jelenléte, illetve dominanciája e területen, ami arra utalhat, hogy a hazai H1 populáció forrása az általunk mintázott területekhez közel esik. Olaszország, a Balkán, Törökország, Erdély és a Kárpát-medencétől keletre levő területek jóval részletesebb mintázása szükséges ahhoz, hogy megállapíthassuk, mik a kárpát-medencei diverzitás forrásai, és mi az endemikusnak tekinthető H1 haplocsoport elterjedési területének határa. 
Számos közös haplotípus jelenléte és így az AMOVA analízis eredménye is azt támasztja alá, hogy Olaszország és a Kárpát-medence genetikailag nem különül el élesen egymástól, ellentétben a Közép-Európa - Ibéria elkülönüléstöl. Ez arra utal, hogy az Alpokon való átjutás nem jelentett különösebb akadályt a gubacsdarazsak számára, vagy képesek voltak kikerülni az Alpok hegyláncait délkelet felöl.

Az észak-európai Synergus umbraculus populáció eredete

Eredményeink arra utalnak, hogy Észak-Európa benépesítése Közép-Európa felöl történhetett nyugati irányú kiterjedéssel, és nem Ibéria felöl. A H2 és H6 haplocsoportok találhatóak meg Németország, Franciaország és az Egyesült Királyság területén, amelyek Ibériából hiányoznak, viszont főként Olaszországban és kisebb mértékben a Kárpát-medencében elterjedtek. Ez a mintázat hasonló más gubacsdarazsaknál tapasztaltakhoz (Stone és Sunnucks, 1993; Rokas és mtsi, 2001, 2003; Stone és mtsi, 2001, 2007).

\section{Gazda specificitás}

A gazda specifikus differenciáció a fajképződés egyik fontos tényezője lehet a növény-növényevő és a gazda-parazita rendszerekben (Abrahamson és mtsi, 2001; Baer és mtsi, 2004; Forbes és mtsi, 2009). Az inkvilin gubacsdarazsak képesek a gazdanövény szöveteit módosítani, hogy a táplálkozásukhoz szükséges körülményeket biztosítsák (Askew, 1961; Ronquist, 1994, Sanver és Hawkins, 2000). A gubacs különböző jellemzői hatással lehetnek az inkvilin darázs peterakási sikerére. Ilyenek lehetnek például a gubacs külső parenchimájának jellegzetességei (pl. ragacsos felszín), a lignifikáció mértéke, vagy a gubacs falvastagsága. Ezekről már ismert, hogy a parazitoidok peterakási sikerét befolyásolhatják (Bailey és mtsi, 2009). A gubacs ezen tulajdonságait a gubacsdarázs kontrollálja (kivétel a Synophrus génusz fajai), és gyakran fajspecifikusak, ami alapján nem zárható ki olyan inkvilin rasszok megjelenése, melyek hasonló típusú gubacsokat részesítenek előnyben. Eredményeink nem támasztják alá ilyen rasszok jelenlétét a Kárpát-medencében, azonban további mintázás szükséges ahhoz, hogy ezt az eredményt a vizsgált fajra általánosíthassuk. Az egyik lehetséges magyarázat a gazdaspecifikus differenciáció hiányára az lehet, hogy az inkvilin darázs a 
gubacsot egy olyan korai fejlődési stádiumában keresi fel, amikor a gubacs felépítésének jellegzetességei és a felszíni struktúrák még nem kifejezettek, így a gazda fajok még nem térnek el ebben a tekintetben. Ezen kívül meghatározó lehet az is, hogy általában magas az évenkénti és fák közötti ingadozás a gubacsok számában és azok típusában (Crawley és Aktheruzzaman, 1988; Crawley és Long, 1995). Ennek ellenére számos gazdaspecifikus inkvilin ismert (pl. Synergus consobrinus, S. dacianus), ami azt feltételezi, hogy bizonyos inkvilin fajok különbséget tudnak tenni a gubacsdarázs gazdák, illetve gubacsaik között. 


\section{Közlemények jegyzéke}

\section{Az értekezés alapjául szolgáló közlemények}

- Bihari P, Sipos B, Melika G, Fehér B, Somogyi K, Stone GN, Pénzes Zs. 2011. Western Palearctic phylogeography of an inquiline gallwasp, Synergus umbraculus. Biological Journal of the Linnean Society 102:750-764 IF: 2.04.

- Pénzes Zs, Melika G, Bozsóki Z, Bihari P, Mikó I, Tavakoli M, Pujade-Villar J, Fehér B, Fülöp D, Szabó K, Bozsó M, Sipos B, Somogyi K, Stone GN. 2009. Systematic re-appraisal of the gall-usurping wasp genus Synophrus Hartig, 1843 (Hymenoptera: Cynipidae: Synergini). Systematic Entomology 34: 688-711 IF: 2.467 .

\section{Egyéb közlemények}

- Ács Z, Challis RJ, Bihari P, Blaxter M, Hayward A, Melika G, Csóka Gy, Pénzes Zs, Pujade-Villar J, Nieves-Aldrey JL, Schönrogge K, Stone GN. 2010. Phylogeny and DNA barcoding of inquiline oak gallwasps (hymenoptera: Cynipidae) of the Western Palearctic. Molecular Phylogenetics and Evolution 55: 210-225 IF: 3.556.

- Tavakoli M, Melika G, Sadeghi S, Pénzes Z, Assareh M, Atkinson R, Bechtold M, Mikó I, Zargaran M, Aligolizade D, Barimani H, Bihari P, Fülöp D, Somogyi K, Challis R, Preuss S, Nicholls J, Stone GN. 2008. New Species of Oak Gallwaps from Iran (Hymenoptera: Cynipidae: Cynipini). Zootaxa 1699: 164 IF: 0.740.

- Álmos PZ, Horváth S, Czibula Á, Raskó I, Sipos B, Bihari P, Béres J, Juhász A, Janka Z, Kálmán J. 2008. H1 tau haplotype-related genomic variation at 17q21.3 
as an Asian heritage of the European Gypsy population. Heredity 101: 416-419. IF: 3.823 .

- Melika G, Pénzes Zs, Mikó I, Bihari P, Ács Z, Somogyi K, Bozsóki Z, Szabó K, Bechtold M, Fári K, Fehér B, Fülöp D, Csóka Gy, Stone GN. A Kárpátmedence tölgyön élő gubacsdarazsai. Könyvfejezet. A Kárpát-medence állatvilágának kialakulása - A Kárpát-medence állattani értékei és faunájának kialakulása, 2007, Budapest. 


\section{Köszönetnyilvánítás}

Mindenekelőtt köszönöm témavezetőmnek, Dr. Pénzes Zsolt egyetemi docensnek a lehetőséget, hogy csoportjában dolgozhattam, valamint a teljes körü támogatást, türelmet és útmutatást, ami munkámhoz és e dolgozat létrejöttéhez nélkülözhetetlen volt.

Köszönettel tartozom az SZBK Genetika Intézetének doktori munkám támogatásáért. Hálás vagyok a Molekuláris Biodiverzitás csoport minden volt munkatársának, különös tekintettel Dr. Sipos Botondnak, Szabó Krisztiánnak, Dr. Somogyi Kálmánnak, Bozsóki Zoltánnak, Bozsó Miklósnak, Fehér Balázsnak és Fülöp Dávidnak a terep- és labormunkában nyújtott segítségükért és azért a baráti légkörért, amiben öröm volt dolgozni.

Köszönöm Melika Georgenak a határozásban nyújtott segítségét és Graham N. Stone-nak, hogy mintáikat rendelkezésemre bocsájtotta, és azt, hogy bizalmukba fogadtak. Mindketten lehetőséget biztosítottak számomra, hogy bepillantást nyerjek kiemelkedő szakmai tevékenységükbe, amiből sokat tanulhattam.

Köszönet illeti Dr. Márk Lászlót, aki következetes érdeklődésével számtalanszor emlékeztetett rá, hogy mi a feladatom. Ez nagyban hozzájárult ahhoz, hogy eljutottam idáig. Hálás vagyok közeli barátaimnak is, akik segítettek, hogy épp ésszel átvészeljem a mélypontokat, és mindvégig ösztönöztek.

Végül, de nem utolsó sorban szeretném megköszönni családom kitartó támogatását, ami lehetővé tette egyetemi és posztgraduális tanulmányaimat, és azt, hogy mindvégig hagyták, hogy a saját fejem után menjek. 


\section{Irodalomjegyzék}

Abe Y, Melika G, Stone GN. 2007. The diversity and phylogeography of cynipid gallwasps (Hymenoptera, Cynipidae) of the Oriental and Eastern Palaearctic regions, and their associated communities. Oriental Insects 41: 169-212.

Abrahamson WG, Eubanks MD, Blair CP, Whipple AV. 2001. Gall flies, inquilines and goldenrods: a model for host-race formation and sympatric speciation. American Zoologist 41: 928-938.

Ács Z, Challis R, Bihari P, Pénzes Z, Blaxter M, Hayward A, Melika G, Pujade-Villar J, Nieves-Aldrey JL, Schönrogge K, Graham NS. 2010. Phylogeny and DNA barcoding of inquiline oak gallwasps (Hymenoptera: Cynipidae) of the Western Palaearctic. Molecular Phylogenetics and Evolution 55: 210-225.

Àcs Z, Melika G, Pénzes Zs, Pujade-Villar J, Stone GN. 2007. The phylogenetic relationships between Dryocosmus, Chilaspis and allied genera of oak gall wasps (Hymenoptera, Cynipidae: Cynipini). Systematic Entomology 32(1): 70—80.

Askew RR. 1961. On the biology of the inhabitants of oak galls of Cynipidae (Hymenoptera) in Britain. Transactions of the Society for British Entomology 14: 237268.

Askew RR. 1971. Parasitic insects. Heinemann Educational Books, London.

Avise JC. 2000. Phylogeography. The history and formation of species. Harvard University Press

Baer CF, Tripp DW, Bjorksten TA, Antolin MF. 2004. Molecular phylogeography of a parasitoid wasp (Diaeretiella rapae): no evidence of host-associated lineages. Ecology 13: $1859-1869$.

Bailey R, Schönrogge K, Cook JM, Melika G, Csóka G, Thúroczy C, Stone GN. 2009. Host niches and defensive extended phenotypes structure parasitoid wasp communities. PLoS Biology 7: e1000179. 
Berlocher SH, Feder JL. 2002. Sympatric speciation in phytophagous insects: moving beyond controversy? Annual Review of Entomology 47: 773- 815.

Brower AVZ. 1994. Rapid morphological radiation and convergence among races of the butterfly Heliconius erato inferred from patterns of mitochondrial DNA evolution. Proceedings of the National Academy of Sciences of the United States of America 91: 6491-6495.

Challis RJ, Mutun S, Nieves-Aldrey J-L, Preuss S, Rokas A, Aebi A, Sadeghi E, Tavakoli M, Stone GN. 2007. Longitudinal range expansion and cryptic eastern species in the western Palaearctic oak gall wasp Andricus coriarius. Molecular Ecology 16: 21032114.

Clement M, Posada D, Crandall K. 2000. TCS: a computer program to estimate gene genealogies. Molecular Ecology 9: 1657-1660.

Comps B, Gömöry D, Letouzey J, Thiébault B, Petit RJ. 2001. Diverging trends between heterozygosity and allelic richness during postglacial colonisation in the European beech. Genetics 157: 389-397.

Cook JM, Rokas A, Pagel M, Stone GN. 2002. Evolutionary shifts between host oak sections and host-plant organs in Andricus gallwasps. Evolution 56: 1821-1830.

Crawley MJ, Long CR. 1995. Alternate bearing, predator satiation and seedling recruitment in Quercus robur. Journal of Ecology 83: 683-696.

Crawley MJ, Aktheruzzaman M. 1988. Individual variation in the phenology of oak trees and its consequences for herbivorous insects. Functional Ecology 2: 409-415.

Deffontaine V, Libois R, Kotlík P, Sommer R, Nieberding C, Paradis E, Searle JB, Michaux JR. 2005. Beyond the Mediterranean peninsulas: evidence of central European glacial refugia for a temperate forest mammal species, the bank vole (Clethrionomys glareolus). Molecular Ecology 14: 1727-1739.

Downie DA, Fisher JR, Granett J. 2001. Grapes, galls, and geography: the distribution of 
nuclear and mitochondrial DNA variation across host plant species and regions in a specialist herbivore. Evolution 55: 1345- 1362.

Dreger-Jauffret F, Shorthouse JD. 1992. Biology of Insect-Induced Galls, Oxford: Oxford University Press.

Dres M, Mallet J. 2002. Host races in plant-feeding insects and heir importance in sympatric speciation. Philosophical Transactions of the Royal Society of London. Series B, Biological Sciences 357: 71-492.

Drummond AJ, Rambaut A. 2007. BEAST: Bayesian evolutionary analysis by sampling trees. BMC Evolutionary Biology 7: 214.

Duffet GH. 1968. Some new interrelationships of Hymenoptera over-wintering within the galls of Andricus kollari (Hartig). Entomological Monthly Magazine 105: 1259-1261.

Ekim T, Guner A. 1986. The Anatolian Diagonal: fact or fiction? Proceedings of the Royal Society of Edinburgh Series B Biological Sciences 89: 69-77.

Excoffier L, Smouse P, Quattro J. 1992. Analysis of molecular variance inferred from metric distances among DNA haplotypes: Application to human mitochondrial DNA restriction data. Genetics 131: 479-491.

Folmer O, Black MB, Hoch W, Lutz RA, Vrijenhock RC. 1994. DNA primers for amplification of mitochondrial cytochrome c oxidase subunit I from metazoan invertebrates. Molecular Marine Biology and Biotechnology 3: 294-299.

Forbes AA, Powell THQ, Stelinski LL, Smith JJ, Feder JL. 2009. Sequential sympatric speciation across trophic levels. Science 323: 776-779.

Fourment M, Gibbs MJ. 2006. PATRISTIC: a program for calculating patristic distances and graphically comparing the components of genetic change. BMC Evolutionary Biology 6: 1.

Hancock JM, Tautz D, Dover GA. 1988. Evolution of the secondary structures and compensatory mutations of the ribosomal RNAs of Drosophila melanogaster. 
Molecular Biology and Evolution 5: 393-414.

Harry M, Solignac M, Lachaise D. 1998. Molecular evidence for parallel evolution of adaptive syndromes in fig-breeding Lissocephala (Drosophilidae). Molecular Phylogenetics and Evolution 9: 542-551.

Hartig T. 1840. Über die Familie der Gallwespen. Zeitschrift für Entomologie (Germar) 2: 176-209.

Guindon S, Gascuel O. 2003. A simple, fast, and accurate algorithm to estimate large phylogenies by maximum likelihood. Systematic Biology: 52: 696-704.

Hayward A, Stone GN. 2006. Comparative phylogeography across two trophic levels: the oak gall wasp Andricus kollari and its chalcid parasitoid Megastigmus stigmatizans. Molecular Ecology 15: 479-489.

Hayward A, Stone GN. 2005. Oak gall wasp communities: Evolution and ecology. Basic and Applied Ecology 6: 435-443.

Hewitt GM. 1999. Post-glacial re-colonization of European biota. Biological Journal of the Linnean Society 68: 87-112.

Huson DH, Bryant D. 2006. Application of Phylogenetic Networks in Evolutionary Studies. Molecular Biology and Evolution 23: 254-267.

Kaya Z, Raynal DJ. 2001. Biodiversity and conservation of Turkish forests. Biological Conservation 97: 131-141.

Kumar S, Tamura K, Nei M. 2004. MEGA3: Integrated Software for Molecular Evolutionary Analysis and Sequence Alignment. Briefings in Bioinformatics 5: 150163.

Librado P, Rozas J. 2009. DnaSP v5: A software for comprehensive analysis of DNA polymorphism data. Bioinformatics 25: 1451-1452. 
Liljeblad J. 2002. Phylogeny and Evolution of Gall Wasps (Hymenoptera: Cynipidae). Doctoral Dissertation, Department of Zoology, Univ. Stockholm, Stockholm.

Lohse K, Sharanowski B, Stone GN. 2010. Quantifying the Pleistocene history of the oak gall parasitoid Cecidostiba fungosa using twenty intron loci. Evolution 64: 2664-2681.

Manos PS, Doyle JJ, Nixon KC. 1999. Phylogeny, biogeography, and processes of molecular differentiation in Quercus subgenus Quercus (Fagaceae). Molecular Pylogenetics and Evolution 12: 333-349

Mayr G. 1872. Die Einmiethler der mitteleuropaischen Eichengallen. Verhandlungen des Zoologisch-Botanischen Vereins in Wien 22: 669-726.

Melika G. 2006. Gall Wasps of Ukraine, Cynipidae. Kyiv: Vestnik zoologii.

Mutun, S. 2010a. Intraspecific genetic variation and phylogeography of the oak gall wasp Andricus caputmedusae (Hymenoptera: Cynipidae): effects of the Anatolian Diagonal. Acta Zoologica Academaiae Scientiarum Hungaricae 56: 153-172.

Mutun, S. 2010b. Intraspecific genetic diversity of the oak gall wasp Andricus lucidus (Hymenoptera: Cynipidae) populations in Anatolia. Turkish Journal of Zoology in press.

Nicholls JA, Fuentes-Utrilla P, Hayward A, Melika G, Csóka G, Nieves-Aldrey J-L, Pujade-Villar J, Tavakoli M, Schönrogge K, Stone GN. 2010a. Community impacts of anthropogenic disturbance: natural enemies exploit multiple routes in pursuit of invading herbivore hosts. BMC Evolutionary Biology 10:322

Nicholls JA, Preuss S, Hayward A, Melika G, Csóka G, Nieves-Aldrey J-L, Askew RR, Tavakoli M, Schönrogge K, Stone GN. 2010b. Concordant phylogeography and cryptic speciation in two Western Palaearctic oak gall parasitoid species complexes. Molecular Ecology 19: 592-609.

Nylander JAA, Buffington ML, Liu Z, Nieves-Aldrey JL, Liljeblad J, Ronquist F. 2004a. Molecular Phylogeny and Evolution of Gall Wasps. Pp. 40 in Nylander, J.A. (ed)."Bayesian Phylogenetics and the Evolution of Gall Wasps", Ph. D. Thesis, Univ. Uppsala, Uppsala. 
Nylander JAA, Ronquist F, Huelsenbeck JP, Nieves-Aldrey JL. 2004b. Bayesian phylogenetic analysis of combined data. Systematic Biology 53: 47-67.

Nylander JAA, 2004c. MrModeltest v2. Program distributed by the author. Evolutionary Biology Centre, Uppsala University.

Oksanen J, Kindt R, Legendre P, O'Hara B, Simpson GL, Solymos P, Stevens HH, Wagner H. 2009. vegan: Community Ecology Package. $R$ package version 1.15-2. http://CRAN.R-project.org/package=vegan

Pénzes Z, Melika G, Bozsóki Z, Bihari P, Mikó I, Tavakoli M, Villar J-P, Fehér B, Fülöp D, Szabó K, Bozsó M, Sipos B, Somogyi K, Stone GN. 2009. Systematic re-appraisal of the gall-usurping wasp genus Synophrus Hartig, 1843 (Hymenoptera: Cynipidae: Synergini). Systematic Entomology 34: 688-711.

Provan J, Bennett KD. 2008. Phylogeographic insights into cryptic glacial refugia. Trends in Ecology and Evolution 23: 564-571.

Pujade-Villar J. 1991. Contribució al coneixement dels cinípids cecidògens dels arbres i arbusts de Catalunya dels cinípids associats a aquests i dels seus paràsits. Doctoral Dissertation, University of Barcelona, Barcelona, Spain.

Pujade-Villar J, Melika G, Ros-Farré P, Àcs Z, Csóka G. 2003. Cynipid inquiline wasps of Hungary, with taxonomic notes on the Western Palaearctic fauna (Hymenoptera: Cynipidae, Cynipinae, Synergini). Folia Entomologica Hungarica 64: 121-170.

Rambaut A, Drummond AJ. 2007. Tracer v1.4. Available from http://beast.bio.ed.ac.uk/Tracer

Rokas A, Atkinson RJ, Webster L, Stone GN. 2003. Out of Anatolia: longitudinal gradients in genetic diversity support a Turkish origin for a circum-Mediterranean gall wasp Andricus quercustozae. Molecular Ecology 12: 2153-2174.

Rokas A, Atkinson R, Brown G, West SA, Stone GN. 2001. Understanding patterns of genetic diversity in the oak gall wasp Biorhiza pallida: demographic history or a 
Wolbachia selective sweep? Heredity 87: 294-305.

Ronquist F. 1994. Evolution of parasitism among closely related species: phylogenetic relationships and the origin of inquilinism in gall wasps (Hymenoptera, Cynipidae). Evolution 48: 241-266.

Ronquist F, Liljeblad J. 2001. Evolution of the gall wasp - host plant association. Evolution 55: 2503-2522.

Ronquist F, Huelsenbeck JP. 2003. MRBAYES 3: Bayesian phylogenetic inference under mixed models. Bioinformatics 19: 1572-1574.

R Development Core Team. 2009. R: A language and environment for statistical computing. R Foundation for Statistical Computing, Vienna, Austria.

Sanver D, Hawkins BA. 2000. Galls as habitats: the inquiline communities of insect galls. Basic and Applied Ecology 1: 3-11.

Schmitt T. 2007. Molecular biogeography of Europe: Pleistocene cycles and postglacial trends. Frontiers in Zoology 4: 11.

Schönrogge K, Stone GN, Crawley MJ. 1996a. Alien herbivores and native parasitoids: rapid development of guild structure in an invading gall wasp, Andricus quercuscalicis (Hymenoptera: Cynipidae). Ecological Entomology 21: 71-80.

Schönrogge K, Stone GN, Crawley MJ. 1996b. Abundance patterns and species richness of the parasitoids and inquilines of the alien gall former Andricus quercuscalicis Burgsdorf (Hymenoptera: Cynipidae). Oikos 77: 507-518.

Shorthouse JD. 1980. Modification of galls of Diplolepis polita by the inquiline Periclistus pirata. Bulletin de la Societe Botanique de France Actualites Botaniques 127: 79-84.

Simmons MP, Ochoterena H. 2000. Gaps as characters in sequence-based phylogenetic analyses. Systematic Biology 49: 369-381. 
Staden R, Beal KF, Bonfield JK. 2000. The Staden package, 1998. Methods in Molecular Biology 132: 115-130.

Stewart JR, Lister AM. 2001. Cryptic northern refugia and the origins of the modern biota. Trends in Ecology and Evolution 16: 608-613.

Stireman JO, Nason JD, Heard SB. 2005. Host associated genetic differentiation in phytophagus insects: general phenomenon or isolated exceptions? Evidence from a goldenrod insect community. Evolution 59(12): 2573-2587

Stone GN, Atkinson RJ, Rokas A, Csóka G, Nieves-Aldrey J-L. 2001. Differential success in northwards range expansion between ecotypes of the marble gallwasp Andricus kollari: a tale of two lifecycles. Molecular Ecology 10: 761-778.

Stone GN, Atkinson RJ, Rokas A, Nieves-Aldrey J-L, Melika G, Ács Z, Csóka G, Hayward A, Bailey R, Buckee C, McVean GAT. 2008. Evidence for widespread cryptic sexual generations in apparently purely asexual Andricus gallwasps. Molecular Ecology 17: $652-665$.

Stone GN, Challis RJ, Atkinson RJ, Csóka Gy, Hayward A, Melika G, Mutun S, Preuss S, Rokas A, Sadeghi E, Schönrogge K. 2007. The phylogeographical clade trade: tracing the impact of human-mediated dispersal on the colonization of northern Europe by the oak gall wasp Andricus kollari. Molecular Ecology 16: 2768-2781.

Stone GN, Cook JM. 1998. The structure of cynipid oak galls: patterns in the evolution of an extended phenotype. Proceedings of the Royal Society of London Series B-Biological Sciences 265: 979-988.

Stone GN, Hernandez-Lopez A, Nicholls JA, di Pierro E, Pujade-Villar J, Melika G, Cook JM. 2009. Extreme host plant conservatism during at least 20 million years of host plant pursuit by oak gall wasps. Evolution 63: 854-869.

Stone GN, Schönrogge K. 2003. The adaptive significance of insect gall morphology. Trends in Ecology Evolution 18: 512-522.

Stone GN, Schönrogge K, Atkinson RJ, Bellido D, Pujade-Villar J. 2002. The population biology of oak gall wasps (Hymenoptera: Cynipidae). Annual Reviews of Entomology 
47: 633-668.

Stone G, Sunnucks PJ. 1993. The population genetics of an invasion through a patchy environment: the cynipid gallwasp Andricus quercuscalicis. Molecular Ecology 2: 251268.

Tamura K, Dudley J, Nei M, Kumar S. 2007. MEGA4: Molecular Evolutionary Genetics Analysis (MEGA) software version 4.0. Molecular Biology and Evolution 24: 15961599.

Thomas CD, Cameron A, Green RE, Bakkenes M, Beaumont LJ, Collingham YC, Erasmus BFN, Ferreira de Siqueira M, Grainger A, Hannah L, Hughes L, Huntley B, van Jaarsveld AS, Midgley GF, Miles L, Ortega-Huerta MA, Townsend Peterson A, Philips OL, Williams SE. 2004. Extinction risk from climate change. Nature 427: 145148.

Thompson JD, Higgins DG, Gibson TJ. 1994. Clustal-W - Improving the sensitivity of progressive multiple sequence alignment through sequence weighting, position-specific gap penalties and weight matrix choice. Nucleic Acids Research 22: 4673-4680.

Ursenbacher S, Carlsson M, Helfer V, Tegelström H, Fumagalli L. 2006. Phylogeography and Pleistocene refugia of the adder (Vipera berus) as inferred from mitochondrial DNA sequence data. Molecular Ecology 15: 3425-3437.

Van Noort S, Stone GN, Whitehead VB, Nieves-Aldrey JL. 2007. Biology of Rhoophilus loewi (Hymenoptera: Cynipoidea: Cynipidae), with implications for the evolution of inquilinism in gall wasps. Biological Journal of the Linnean Society 90: 153-172.

Varga Z. 2008. Mountain coniferous forests, refugia and butterflies. Molecular Ecology 17: $2101-2106$

Weir BS. 1996. Genetic Data Analysis II: Methods for Discrete Population Genetic Data, Sunderland: Sinauer Assoc. Inc.

Willis KJ, Rudner E, Sümegi P. 2000. The full-glacial forests of Central and Southern 
Europe. Quaternary Research 53: 203-213.

Willis KJ, van Andel TH. 2004. Trees or no trees? The enviroments of Central and Eastern Europe during the Last Glaciation. Quaternary Science Reviews 23: 2369-2387. 


\section{Összefoglaló}

Az ízeltlábúak között többször is kialakult a gubacsindukálás képessége az evolúció során. A gubacsképzők közül az egyik legnagyobb és egyben a legváltozatosabb csoport a gubacsdarazsak (Hymenoptera: Cynipidae) családja. A Cynipidae magába foglal egy tribuszt, melynek tagjai az evolúció során elvesztették gubacsindukáló képességüket (Hymenoptera: Cynipidae: Synergini), lárvájuk más gubacsképző fajok mellett társbérlőként (inkvilin) fejlődik. Ezen fajok képesek a növényi szövetek differenciációjának módosításával saját lárvakamrát kialakítani a gubacsban, és sajátos táplálószövet differenciációt indukálni.

A tölgygubacsok egy jellegzetes, viszonylag zárt életközösséget rejtenek, melyben a gubacsképző lárváján kívül társbérlők, parazitoidok és hiperparazitoidok is élhetnek. Ezek közül a legkevésbé kutatott és ismert trofikus szint a társbérlők szintje. Ennek egyik oka az lehet, hogy a Synergini fajok határozása nehéz feladat, nagy tapasztaltot igényel. A Synergini tribusz hozzávetőleg 176 fajt számlál, melyböl 48 a Nyugat Palearktikumban is megtalálható. Számos filogenetikai és taxonómiai kérdés tisztázatlan a társbérlőkkel kapcsolatban, melyek megválaszolásához molekuláris filogenetikai elemzésre is szükség lehet a morfológiai alapú vizsgálatok mellett. Gubacsdarazsak esetén gyakran használt molekuláris markerek a magi 28S D2 lokusz, valamint a mitokondriális citokróm oxidáz I alegység (COI) és a citokróm b (cytb) lokuszok. A 28S D2 génusz szinten, utóbbi két mitokondriális marker fajon belül mutat megfelelő változatosságot.

Az általunk tanulmányozott egyik társbérlő csoport a Synophrus génusz (Hymenoptera: Cynipidae: Synergini), mely több szempontból is kiemelésre érdemes. A Synophrus nőstény korai fejlődési stádiumú gubacsba petézik, majd gyorsan átveszi a szabályozást, kiszorítva a gubacsdarázs gazdát, amely többnyire ismeretlen. A Synophrus fajok az inkvilin darazsak között egyedülálló módon fajspecifikus gubaccsal jellemezhetőek, melynek mérete, morfológiája és lokalizációja azonban jelentős változatosságot mutat. Vizsgáltunk fő célja a génuszon belüli filogenetikai kapcsolatok tisztázása volt 28S D2 és COI markerek használatával.

Vizsgálatunkat megelőzően a Nyugat Palearktikumban 3 Synophrus faj volt 
ismert: a S. pilulae Houard, 1911, a S. politus Hartig, 1843, és a S. olivieri Kieffer, 1898. Molekuláris filogenetikai eredményeink és a diagnosztikus morfológiai karakterek ezt követő újraértékelése alapján további négy, tudományra új fajt írtak le: Synophrus hungaricus Melika és Mikó, 2009, S. libani Melika és Pujade-Villar, 2009, S. syriacus Melika, 2009 és S. hispanicus Pujade-Villar, 2009.

Az általunk rekonstruált molekuláris filogenetika alapján az összes nyugat palearktikus Synophrus faj egy monofiletikus egységet alkot. A vizsgálatunkba bevont Saphonecrus fajok ezzel szemben nem monofiletikusak. A Synophrus génusz testvércsoportját a Saphonecrus lusitanicus és Sa. barbotini fajpár alkotja, míg a Sa. haimi és $S a$. undulatus fajpár, valamint a $S a$. connatus fajok egy ettől elkülönült leszármazási vonalat képeznek. A Sa. connatus filogenetikai helyzete bizonytalan.

A Synophrus génusz fajai két leszármazási vonalra oszthatóak: a (i) $S$. hispanicus - hungaricus - olivieri, valamint a (ii) S. pilulae - politus - libani - syriacus csoportokra. Az első csoportba egy spanyol ( $S$. hispanicus) egy közép-európai ( $S$. hungaricus) és egy iráni/török (S. olivieri) faj tartozik, újabb példát szolgáltatva egy iráni-spanyol fajpárra. A második leszármazási vonalban is megfigyelhető ehhez hasonló földrajzi elkülönülés, amennyiben a $S$. syriacus (Irán és Szíria) és a S. libani (Libanon) fajok egy monoflietikus egységet alkotnak, melynek testvércsoportját a szélesebb elterjedésű (Magyarország, Olaszország, Törökország) S. politus faj alkotja. A $S$. pilulae képezi a $S$. politus, $S$. syriacus és $S$. libani fajok testvércsoportját, elterjedési területe Közép-Európa.

A Synophrus génusz fentebb említett két leszármazási vonala gubacsmorfológia alapján is elkülönülni látszik. Az első csoportra (S. hispanicus - hungaricus - olivieri) fiatal hajtásokon megjelenő szabálytalan formájú duzzanat jellemző. A S. olivieri gubacsa többkamrás. A második csoportra (S. pilulae - politus - libani - syriacus) többnyire szabályosan gömbszerü rügygubacs jellemző. A $S$. politus gubacsok lokalizációja változatos. Mivel a gubacs lokalizációt a gubacsindukáló faj nőstényének peterakási preferenciája határozza meg, ezt a változatosságot kétféleképpen magyarázhatjuk: (i) a gubacsdarázs gazda többféle növényi szerven képez gubacsot, vagy (ii) a $S$. politus több gazdafajt is támad, melyek különböző növényi szervekhez köthetőek.

Vizsgálataink másik célpontja a Synergus umbraculus Olivier, 1791 társbérlő faj 
volt, mely a Synergini tribusz legnépesebb és taxonómiai szempontból leginkább problémás génuszának tagja. E faj az egyik legelterjedtebb tölgygubacs inkvilin a Nyugat Palearktikumban, széles gazdaspecificitású, föleg Andricus (Hymenoptera: Cynipidae: Cynipini) fajok aszexuális gubacsaiban fejlődik. Már korábban is sejthető volt, hogy a $S$. umbraculus kriptikus fajok komplexe, ezt a sejtést egy, a Synergini molekuláris alapú filogenetikai rekonstrukcióját célzó vizsgálat nemrég megerősítette. E tanulmány alapján a morfológiailag $S$. umbraculus-ként meghatározott egyedek 4 különálló MOTU-ba sorolhatók, melyek közül a minták java részét tartalmazó monofiletikus csoportot tekintjük a $S$. umbraculus fajnak, és ez képezte vizsgálatunk tárgyát. Ismert, hogy a Kárpát-medence gubacsdarázs faunája kiemelkedően gazdag, emellett molekuláris alapú vizsgálatok is kimutatták néhány gubacsindukáló Cynipini faj magas fajszintű diverzitását. Célunk elsősorban a kárpát-medencei populáció genetikai diverzitásának elemzése volt, figyelembe véve a kolonizációs történet és a gubacsképző gazdák szerinti differenciáció hatását is. Emellett célunk volt egy Nyugat Palearktikum léptékü filogeográfiai elemzés elvégzése az összes feltételezett refúgiális terület bevonásával.

239 cytb szekvencia alapján 8 haplocsoportot tudtunk elkülöníteni (H1-H8), melyek közül 6 megtalálható hazánkban is. A COI marker ezt a csoportosítást megerősítette, míg a 28S D2 marker nem biztosított megfelelő felbontást. A Kárpátmedence kiemelkedő genetikai diverzitását mutattuk ki, melynek egyik oka a mintázás sajátságaiban keresendő. A kiemelkedő diverzitás fő oka azonban a különböző leszármazási sorok jelenléte. A haplocsoportok földrajzi elterjedése és más régiókkal közös haplotípusok jelenléte alapján feltételezzük, hogy hazánk keveredési zónának tekinthető, melyet több alkalommal és több refúgium felől is kolonizáltak populációk. Emellett hazánkra egy endemikus haplocsoport dominanciája is jellemző. Erős kapcsolatot mutattunk ki Olaszország és Magyarország között, valamint kisebb mértékben hazánk és Törökország között is.

Annak ellenére, hogy a kárpát-medencei populáció genetikai diverzitása kiemelkedő, AMOVA eredményeink alapján ez a diverzitás csak csekély mértékben struktúrált térben. Ehhez hasonló mintázatot az Andricus quercustozae és az A. quercuscalicis gubacsindukáló darazsak esetén is sikerült már kimutatni.

A tölgygubacs gazda szerinti differenciációt a több évig tartó és részletes 
mintázás ellenére csak egy területen (Mátra régió), a négy leggyakoribb gubacsdarázs gazda (Andricus lucidus, A.lignicolus, A. infectorius, A. kollari) figyelembe vételével tudtuk vizsgálni. Gazda rasszok jelenlétét nem sikerült kimutatnunk AMOVA alapján, azonban ennek az eredménynek az általánosításához kiterjedtebb mintázásra lenne szükség.

A Nyugat Palearktikum filogeográfiai elemzése kifejezett genetikai struktúra jelenlétére utal, noha ezt megfelelő óvatossággal kell kezelnünk, mivel vizsgálatunk mindössze egyetlen, mitokondriális markeren alapul. Az Anatóliai Diagonál és a Pireneusok hatása a Törökország - Irán illetve az Ibéria - Közép-Európa elkülönülés alapján jól kivehető, az iráni és az ibériai populáció saját, diagnosztikus leszármazási vonalakkal jellemezhetö (H8, illetve H7 és H3 haplocsoportok). Ezzel szemben az Alpok vélhetőleg nem képez jelentős barriert, mivel az olasz és a magyar populációk szoros kapcsolatát sikerült kimutatnunk. Eredményeink továbbá arra utalnak, hogy Németország, Franciaország és a Brit szigetek posztglaciális benépesítése KözépEurópa felől történhetett. Ezekről a területekről az ibériai régióra jellemző haplotípusok teljesen hiányoznak. Mindezek a filogeográfiai sajátságok hasonlítanak a gubacsközösség más tagjaira jellemző mintázatokhoz, azonban vizsgálatunk az első, amely egy inkvilin gubacsdarázs genetikai diverzitását elemzi. 


\section{Summary}

Gall induction has evolved many times among arthropods. Gall wasps (Hymenoptera: Cynipidae) comprise one of the most species-rich and diverse groups of gallers and are special in many ways. All cynipid gall wasps are phytophagous, although they belong to the superfamily Cynipoidae which are mainly endoparasitic insects. Within the Cynipidae, a group of species (comprising the inquiline tribe Synergini) has lost the ability to induce galls, but are obligate inhabitants of galls induced by other species. These herbivorous inquilines are also able to modify the differentiation of plant tissues of galls to form larval chambers within which the larvae feed on highly specialized nutritive plant tissues.

Cynipid galls represent a habitat and food resource for a relatively closed community of arthropods, in which parasitoid, hyperparasitoid and inquiline species may also be found beside the gall inducers. The least known and studied trophic level of the oak gall community is the inquilines. One of the underlying causes may be that the taxonomic identification of Synergini species is difficult and requires a lot of experience. The tribe Synergini includes about 176 species of which 48 is present in the Western Palearctic. A number of important taxonomic and phylogenetic issues remain unresolved for cynipid inquilines, and in order to address them, molecular phylogenetic analyses may be needed besides the morphological re-appriasal of diagnostic specieslevel characters. Previous works on gall wasps have shown that a fragment of the nuclear 28S D2 expansion segment is applicable for species level differentiation, while the mitochondrial cytochrome oxidase I (COI) and cytochrome b (cytb) genes are useful for within species studies.

One of the inquiline groups we have studied in detail is the genus Synophrus (Hymenoptera: Cynipidae: Synergini), which is notable in many respects. Synophrus species attack host galls at a very early stage of gall development, grow faster than the host larva, which is finally eliminated because of food deprivation and is therefore unknown. Synophrus larvae 'hijack' gall development and cause species-specific gall morphology, which is unusual among inquilines. However, there is significant diversity in the morphology, size and location of Synophrus galls. Our main goal was to assess 
phylogenetic relationships within the genus using nuclear (28S D2) and mitochondrial (COI) sequence information.

Previously, three Western Palearctic Synophrus species were recognized: $S$. pilulae Houard, 1911, S. politus Hartig, 1843, and S. olivieri Kieffer, 1898. Based on our molecular phylogenetic results and subsequent re-appraisal of diagnostic morphological characters four additional new species have been established: Synophrus hungaricus, Melika and Mikó, S. libani, Melika and Pujade-Villar, S. syriacus, Melika and S. hispanicus, Pujade-Villar.

Our dataset support the monophyly of all Western Palearctic Synophrus species but reject monophyly of the studied Saphonecrus species. The genus Synophrus and Saphonecrus barbotini together with $\mathrm{Sa}$. lusitanicus are sister groups, while $\mathrm{Sa}$. connatus and the Sa. haimi - Sa. undulatus species pair form a separate lineage. The affiliation of Sa. connatus remains unresolved.

Two lineages come out as strongly supported within Synophrus, one comprising S. hispanicus - hungaricus - olivieri and the other comprising S. pilulae - politus libani-syriacus. In the first lineage each species represents a distinct geographic region and they form species pairs. For example S. hispanicus (Spain) and S. olivieri (Iran, Turkey) can be regarded as an Iberian-Iranian/Turkish species pair. In the second lineage, S. syriacus (Iran, Syria) and S. libani (Lebanon) form a monophyletic group, which is the sister group of the more widely dispersed S. politus (Hungary, Italy, Turkey). S. pilulae (Hungary, Austria) forms the sister group of these three species of the second lineage.

The two lineages mentioned above can be differentiated on the basis of gall morphology as well. Species of the first lineage (S. hispanicus - hungaricus - olivieri) emerge from irregular swellings in twigs. S. olivieri has multilocular galls. Species of the second lineage (S. pilulae - politus - libani - syriacus) emerge from more regularly spherical bud galls. The location of S. politus galls shows considerable variation. Because gall location is determined by the oviposition preference of the females of the host gall wasp species, this variation suggests either that host gall wasp species show occasional variation in preferred gall induction sites, or that $S$. politus attacks different host gall wasp species, inducing galls in different locations. 
The other object of our study was the inquiline species Synergus umbraculus Olivier, 1791, which belongs to the largest and most problematic genus of the Synergini, the genus Synergus. This species is widely distributed in the Western Palearctic and has a wide range of cynipid hosts, but most frequently develops in the asexual galls of Andricus species (Hymenoptera: Cynipidae: Cynipini). Previously it was hypothesized that $S$. umbraculus is a complex of cryptic species. This was confirmed in a recent study focusing on the sequence-based phylogenetic reconstruction of the tribe Synergini. In this recent study it was demonstrated that, as currently recognized on the basis of morphology, S. umbraculus comprises four distinct molecular taxa (MOTUs). In the present study, we examine a single monophyletic lineage that includes $>90 \%$ of the sequenced individuals, and refer to it as $S$. umbraculus. It is known that the gall wasp fauna of the Carpathian Basin is rich, and sequence-based studies reported high within- species genetic diversity in a number of gall-inducing cynipid species. Our main goal was to analyze the genetic diversity of the S. umbraculus population of the Carpathian Basin, considering the effects of Quaternary glaciations and possible cynipid host-associated differentiation (HAD). Besides, we wanted to examine phylogeographic patterns across the Western Palaearctic in an analysis incorporating samples from all putative southern glacial refugia.

Based on 239 cytb sequences 8 haplotype groups can be defined (haplogroups, H1-H8), of which 6 are present in the Carpathian Basin. COI sequences supported the same subdivison, while 28S D2 sequences showed low variability. Perhaps reflecting our sampling effort, we found the highest genetic diversity in the Caprathian Basin, but the main cause of the significant genetic diversity is the presence of different haplogroups. Based on the spatial distribution of haplogroups and the presence of shared haplotypes with other regions we assume that the Carpathian Basin is an admixture zone, which was repeatedly colonized from different sources in the past and present interglacials. We also found an endemic haplogroup in Hungary. Shared haplotypes and pairwise $\Phi_{\mathrm{ST}}$ values support strong genetic affinity between Italy and the Carpathian Basin and, to a lesser extent, between the Carpathian Basin and Turkey.

Although the genetic diversity is high in the Carpathian Basin, AMOVA showed low population substructure. This pattern parallels those seen in the cynipid gall inducers Andricus quercustozae and A. quercuscalicis. 
Despite targeted sampling, we were unable to rear balanced samples from the same set of hosts in replicate sites, excluding joint analysis of host association and spatial structure. We therefore tested for HAD using samples from the Mátra region (N $=55)$ of the Carpathian Basin only, considering the four most common cynipid hosts (Andricus lucidus, A.lignicolus, A. infectorius, A. kollari). AMOVA showed no sign of $\mathrm{HAD}$ but further sampling is required to test the generality of this result.

Our data suggest considerable genetic structure across the Western Palearctic, although it is important to emphasize that the present study is based on a single mitochondrial locus and therefore, the inferences of the associated species tree must be made with caution. Regionally diagnostic lineages in each of Iberia (H7 and H3) and Iran (H8), and pairwise $\Phi_{\mathrm{ST}}$ values indicate strong divisions between Iberia and Central Europe, and between Iran and Turkey, which may be related with the mountain ranges of the Pyrenees and the Anatolian Diagonal. In contrast, we found strong genetic affinity between Italy and the Carpathian Basin, which suggests that the Alps do not prevent gall wasp dispersal. Our data support the colonization of Germany, France and the United Kingdom by westward expansion from Central Europe and not from Iberia, since haplogroups associated with Iberia $(\mathrm{H} 3, \mathrm{H} 7)$ are not present in these northern postglacial populations. These patterns in many ways parallel those seen in other components of the oak gall wasp community, including gall inducers and their parasitoids. 


\section{Függelék}

1. függelék A Synergus umbraculus mintákra vonatkozó adatok táblázata. A "Régió" oszlopban mind a Nyugat Palearktikum, mind a Kárpát-medence régióit jelöltük. A régiókód nélküli mintákat kihagytuk a térbeli struktúrára vonatkozó vizsgálatokból. A tölgy, illetve gubacsdarázs gazdát nem minden esetben sikerült pontosan meghatározni, ezeket a megfelelö oszlopban kérdőjellel jelöltük, és az ilyen mintákat kihagytuk a gazdaspecificitást célzó vizsgálatokból. A lelőhelyet jelölő hosszúsági és szélességi adatokat tizedes fok (DD, decimal degrees) formájában adtuk meg. 


\begin{tabular}{|c|c|c|c|c|c|c|c|c|c|}
\hline Templát & Haplotípus & Haplocsoport & $\begin{array}{l}\text { Tölgy faj } \\
\text { (Quercus) }\end{array}$ & $\begin{array}{l}\text { Gubacs } \\
\text { (Andricus) }\end{array}$ & Regió & Gyűjtési hely & Szélesség & Hosszúság & $\begin{array}{l}\text { Acession } \\
\text { number }\end{array}$ \\
\hline 537 & HT01 & $\mathrm{H} 1$ & petraea & lignicolus & $\mathrm{CB}$ & Köszeg & 47.38 & 16.55 & GU386377 \\
\hline 535 & НT01 & $\mathrm{H} 1$ & pubescens & lignicolus & CB & Zemplén & 48.36 & 21.37 & GU386377 \\
\hline 539 & HT01 & $\mathrm{H} 1$ & pubescens & lignicolus & CB, Aggtelek & Aggtelek & 48.47 & 20.5 & GU386377 \\
\hline 522 & HT01 & $\mathrm{H} 1$ & petraea & lignicolus & CB, Aggtelek & Jósvafő & 48.48 & 20.55 & GU386377 \\
\hline 523 & НT01 & $\mathrm{H} 1$ & petraea & lignicolus & CB, Aggtelek & Jósvafő & 48.48 & 20.55 & GU386377 \\
\hline 524 & HT01 & $\mathrm{H} 1$ & petraea & lignicolus & CB, Aggtelek & Jósvafö & 48.48 & 20.55 & GU386377 \\
\hline 556 & НТ01 & $\mathrm{H} 1$ & pubescens & lucidus & CB, Aggtelek & Jósvafő & 48.48 & 20.55 & GU386377 \\
\hline 558 & HT01 & $\mathrm{H} 1$ & pubescens & lucidus & CB, Aggtelek & Jósvafő & 48.48 & 20.55 & GU386377 \\
\hline 560 & HT01 & $\mathrm{H} 1$ & pubescens & lucidus & CB, Aggtelek & Jósvafő & 48.48 & 20.55 & GU386377 \\
\hline 530 & HT01 & $\mathrm{H} 1$ & petraea & lignicolus & CB, Aggtelek & Szőlősardó & 48.44 & 20.63 & GU386377 \\
\hline 533 & HT01 & $\mathrm{H} 1$ & & lignicolus & CB, Aggtelek & Szőlősardó & 48.44 & 20.63 & GU386377 \\
\hline 550 & НT01 & $\mathrm{H} 1$ & & lignicolus & CB, Aggtelek & Szőlősardó & 48.44 & 20.63 & GU386377 \\
\hline 553 & НT01 & $\mathrm{H} 1$ & & lignicolus & $\mathrm{CB}$, Aggtelek & Szőlősardó & 48.44 & 20.63 & GU386377 \\
\hline 554 & НT01 & $\mathrm{H} 1$ & & lignicolus & CB, Aggtelek & Szőlősardó & 48.44 & 20.63 & GU386377 \\
\hline 566 & НТ01 & $\mathrm{H} 1$ & petraea & lucidus & CB, Eger & Eger & 47.9 & 20.37 & GU386377 \\
\hline 567 & НT01 & $\mathrm{H} 1$ & petraea & infectorius & $\mathrm{CB}$, Eger & Eger & 47.9 & 20.37 & GU386377 \\
\hline 367 & НT01 & $\mathrm{H} 1$ & robur & kollari & CB, Gödöllő & Gödöllő & 47.6 & 19.35 & GU386377 \\
\hline 10045 & НT01 & $\mathrm{H} 1$ & robur & lignicolus & CB, Gödöllő & Gödöllő & 47.6 & 19.35 & GU386377 \\
\hline 22296 & НT01 & $\mathrm{H} 1$ & robur & infectorius & CB, Gödöllő & Gödöllő & 47.6 & 19.35 & GU386377 \\
\hline 527 & НT01 & $\mathrm{H} 1$ & petraea & lignicolus & CB, Mátra & Mátra, Sár-hegy & 47.8 & 19.97 & GU386377 \\
\hline 528 & НT01 & $\mathrm{H} 1$ & petraea & lignicolus & $\mathrm{CB}$, Mátra & Mátra, Sár-hegy & 47.8 & 19.97 & GU386377 \\
\hline 529 & НТ01 & $\mathrm{H} 1$ & petraea & lignicolus & $\mathrm{CB}$, Mátra & Mátra, Sár-hegy & 47.8 & 19.97 & GU386377 \\
\hline 500 & HT01 & $\mathrm{H} 1$ & petraea & glutinosus & CB, Mátra & Mátra, Sás-tó & 47.843 & 19.96 & GU386377 \\
\hline 501 & НT01 & $\mathrm{H} 1$ & petraea & ?infectorius & CB, Mátra & Mátra, Sás-tó & 47.843 & 19.96 & GU386377 \\
\hline 503 & НT01 & $\mathrm{H} 1$ & petraea & ?infectorius & $\mathrm{CB}$, Mátra & Mátra, Sás-tó & 47.843 & 19.96 & GU386377 \\
\hline 511 & HT01 & $\mathrm{H} 1$ & petraea & lignicolus & $\mathrm{CB}$, Mátra & Mátra, Sás-tó & 47.843 & 19.96 & GU386377 \\
\hline 514 & НT01 & $\mathrm{H} 1$ & petraea & lucidus & CB, Mátra & Mátra, Sás-tó & 47.843 & 19.96 & GU386377 \\
\hline 722 & НT01 & $\mathrm{H} 1$ & petraea & lucidus & $\mathrm{CB}$, Mátra & Mátra, Sás-tó & 47.843 & 19.96 & GU386377 \\
\hline 726 & НТ01 & $\mathrm{H} 1$ & petraea & kollari & $\mathrm{CB}$, Mátra & Mátra, Sás-tó & 47.843 & 19.96 & GU386377 \\
\hline 344 & НT01 & $\mathrm{H} 1$ & petraea & lignicolus & $\mathrm{CB}$, Mátra & Mátrafüred & 47.83 & 19.97 & GU386377 \\
\hline 346 & HT01 & $\mathrm{H} 1$ & pubescens & kollari & $\mathrm{CB}$, Mátra & Mátrafüred & 47.83 & 19.97 & GU386377 \\
\hline 347 & HT01 & $\mathrm{H} 1$ & pubescens & kollari & CB, Mátra & Mátrafüred & 47.83 & 19.97 & GU386377 \\
\hline 385 & HT01 & $\mathrm{H} 1$ & petraea & infectorius & CB, Mátra & Mátrafüred & 47.83 & 19.97 & GU386377 \\
\hline 459 & НT01 & $\mathrm{H} 1$ & petraea & glutinosus & CB, Mátra & Mátrafüred & 47.83 & 19.97 & GU386377 \\
\hline 467 & HT01 & $\mathrm{H} 1$ & petraea & kollari & $\mathrm{CB}$, Mátra & Mátrafüred & 47.83 & 19.97 & GU386377 \\
\hline
\end{tabular}




\begin{tabular}{|c|c|c|c|c|c|c|c|c|c|}
\hline 582 & HT01 & $\mathrm{H} 1$ & petraea & glutinosus & CB, Mátra & Mátrafüred & 47.83 & 19.97 & GU386377 \\
\hline 589 & HT01 & $\mathrm{H} 1$ & petraea & kollari & CB, Mátra & Mátrafüred & 47.83 & 19.97 & GU386377 \\
\hline 591 & HT01 & $\mathrm{H} 1$ & petraea & lucidus & CB, Mátra & Mátrafüred & 47.83 & 19.97 & GU386377 \\
\hline 719 & НT01 & $\mathrm{H} 1$ & petraea & lucidus & CB, Mátra & Mátrafüred & 47.83 & 19.97 & GU386377 \\
\hline 721 & НT01 & $\mathrm{H} 1$ & petraea & lucidus & CB, Mátra & Mátrafüred & 47.83 & 19.97 & GU386377 \\
\hline 406 & НT01 & $\mathrm{H} 1$ & pubescens & lucidus & CB, Mátra & Szentkút & 47.49 & 17.49 & GU386377 \\
\hline 542 & НT01 & $\mathrm{H} 1$ & robur & lignicolus & CB, Mecsek & Orfü & 46.14 & 18.15 & GU386377 \\
\hline 475 & НT01 & $\mathrm{H} 1$ & robur & ?infectorius & CB, Mecsek & Pécsvárad & 46.17 & 18.4 & GU386377 \\
\hline 477 & НT01 & $\mathrm{H} 1$ & robur & ?infectorius & CB, Mecsek & Pécsvárad & 46.17 & 18.4 & GU386377 \\
\hline 486 & HT01 & $\mathrm{H} 1$ & robur & lignicolus & CB, Mecsek & Pécsvárad & 46.17 & 18.4 & GU386377 \\
\hline 487 & НT01 & $\mathrm{H} 1$ & robur & lignicolus & CB, Mecsek & Pécsvárad & 46.17 & 18.4 & GU386377 \\
\hline 492 & НT01 & $\mathrm{H} 1$ & pubescens & lucidus & CB, Mecsek & Pécsvárad & 46.17 & 18.4 & GU386377 \\
\hline 494 & НT01 & $\mathrm{H} 1$ & robur & lucidus & CB, Mecsek & Pécsvárad & 46.17 & 18.4 & GU386377 \\
\hline 580 & НT01 & $\mathrm{H} 1$ & pubescens & polycerus & CB, Mecsek & Pécsvárad & 46.17 & 18.4 & GU386377 \\
\hline 453 & HT02 & $\mathrm{H} 1$ & & lignicolus & $\mathrm{CB}$ & Debrecen & 47.58 & 21.63 & GU386378 \\
\hline 575 & HT02 & $\mathrm{H} 1$ & pubescens & quercustozae & $\mathrm{CB}$ & Fertőrákos & 47.72 & 16.65 & GU386378 \\
\hline 536 & HT02 & $\mathrm{H} 1$ & pubescens & lignicolus & CB & Zemplén & 48.36 & 21.37 & GU386378 \\
\hline 520 & НT02 & $\mathrm{H} 1$ & petraea & lignicolus & CB, Aggtelek & Jósvafő & 48.48 & 20.55 & GU386378 \\
\hline 521 & HT02 & $\mathrm{H} 1$ & petraea & lignicolus & $\mathrm{CB}$, Aggtelek & Jósvafö & 48.48 & 20.55 & GU386378 \\
\hline 545 & HT02 & $\mathrm{H} 1$ & petraea & lignicolus & $\mathrm{CB}$, Aggtelek & Jósvafö & 48.48 & 20.55 & GU386378 \\
\hline 549 & HT02 & $\mathrm{H} 1$ & pubescens & lignicolus & CB, Aggtelek & Jósvafő & 48.48 & 20.55 & GU386378 \\
\hline 555 & HT02 & $\mathrm{H} 1$ & petraea & lucidus & $\mathrm{CB}$, Aggtelek & Jósvafö & 48.48 & 20.55 & GU386378 \\
\hline 515 & HT02 & $\mathrm{H} 1$ & petraea & lignicolus & CB, Eger & Eger & 47.9 & 20.37 & GU386378 \\
\hline 564 & НT02 & $\mathrm{H} 1$ & petraea & lucidus & CB, Eger & Eger & 47.9 & 20.37 & GU386378 \\
\hline 568 & HT02 & $\mathrm{H} 1$ & petraea & infectorius & CB, Eger & Eger & 47.9 & 20.37 & GU386378 \\
\hline 525 & HT02 & $\mathrm{H} 1$ & petraea & lignicolus & $\mathrm{CB}$, Mátra & Mátra, Sár-hegy & 47.8 & 19.97 & GU386378 \\
\hline 723 & HT02 & $\mathrm{H} 1$ & petraea & lucidus & CB, Mátra & Mátra, Sár-hegy & 47.8 & 19.97 & GU386378 \\
\hline 466 & HT02 & $\mathrm{H} 1$ & petraea & lucidus & CB, Mátra & Mátra, Sás-tó & 47.843 & 19.96 & GU386378 \\
\hline 502 & НT02 & $\mathrm{H} 1$ & petraea & ?infectorius & CB, Mátra & Mátra, Sás-tó & 47.843 & 19.96 & GU386378 \\
\hline 720 & HT02 & $\mathrm{H} 1$ & petraea & lucidus & CB, Mátra & Mátra, Sás-tó & 47.843 & 19.96 & GU386378 \\
\hline 461 & HT02 & $\mathrm{H} 1$ & petraea & lignicolus & CB, Mátra & Mátrafüred & 47.83 & 19.97 & GU386378 \\
\hline 463 & HT02 & $\mathrm{H} 1$ & petraea & infectorius & CB, Mátra & Mátrafüred & 47.83 & 19.97 & GU386378 \\
\hline 468 & НT02 & $\mathrm{H} 1$ & petraea & glutinosus & $\mathrm{CB}$, Mátra & Mátrafüred & 47.83 & 19.97 & GU386378 \\
\hline 469 & НT02 & $\mathrm{H} 1$ & petraea & lucidus & CB, Mátra & Mátrafüred & 47.83 & 19.97 & GU386378 \\
\hline 583 & HT02 & $\mathrm{H} 1$ & petraea & infectorius & CB, Mátra & Mátrafüred & 47.83 & 19.97 & GU386378 \\
\hline 585 & HT02 & $\mathrm{H} 1$ & petraea & infectorius & $\mathrm{CB}$, Mátra & Mátrafüred & 47.83 & 19.97 & GU386378 \\
\hline 592 & HT02 & $\mathrm{H} 1$ & petraea & lucidus & CB, Mátra & Mátrafüred & 47.83 & 19.97 & GU386378 \\
\hline
\end{tabular}




\begin{tabular}{|c|c|c|c|c|c|c|c|c|c|}
\hline 594 & HT02 & $\mathrm{H} 1$ & petraea & lucidus & CB, Mátra & Mátrafüred & 47.83 & 19.97 & GU386378 \\
\hline 540 & HT02 & $\mathrm{H} 1$ & robur & lignicolus & CB, Mecsek & Orfü & 46.14 & 18.15 & GU386378 \\
\hline 410 & HT02 & $\mathrm{H} 1$ & ?pubescens & dentimitratus & CB, Mecsek & Pécs & 46.07 & 18.23 & GU386378 \\
\hline 482 & HT02 & $\mathrm{H} 1$ & robur & lignicolus & CB, Mecsek & Pécsvárad & 46.17 & 18.4 & GU386378 \\
\hline 488 & HT02 & $\mathrm{H} 1$ & robur & lignicolus & CB, Mecsek & Pécsvárad & 46.17 & 18.4 & GU386378 \\
\hline 489 & HT02 & $\mathrm{H} 1$ & robur & lignicolus & CB, Mecsek & Pécsvárad & 46.17 & 18.4 & GU386378 \\
\hline 490 & НT02 & $\mathrm{H} 1$ & pubescens & lucidus & CB, Mecsek & Pécsvárad & 46.17 & 18.4 & GU386378 \\
\hline 493 & HT02 & $\mathrm{H} 1$ & robur & lucidus & CB, Mecsek & Pécsvárad & 46.17 & 18.4 & GU386378 \\
\hline 638 & HT02 & $\mathrm{H} 1$ & & quercustozae & IT & ITALY, Moiola & 44.32 & 7.39 & GU386378 \\
\hline 714 & HT02 & $\mathrm{H} 1$ & & quercustozae & IT & ITALY, Moiola & 44.32 & 7.39 & GU386378 \\
\hline 716 & НТ03 & H5 & petraea & lignicolus & $\mathrm{CB}$, Aggtelek & Jósvafő & 48.48 & 20.55 & GU386379 \\
\hline 516 & НТ03 & H5 & petraea & lignicolus & $\mathrm{CB}$, Eger & Eger & 47.9 & 20.37 & GU386379 \\
\hline 563 & НТ03 & H5 & petraea & lucidus & CB, Eger & Eger & 47.9 & 20.37 & GU386379 \\
\hline 507 & НТ03 & H5 & petraea & kollari & $\mathrm{CB}$, Mátra & Mátra, Sás-tó & 47.843 & 19.96 & GU386379 \\
\hline 512 & НТ03 & H5 & petraea & lignicolus & CB, Mátra & Mátra, Sás-tó & 47.843 & 19.96 & GU386379 \\
\hline 330 & НТ03 & H5 & pubescens & kollari & CB, Mátra & Mátrafüred & 47.83 & 19.97 & GU386379 \\
\hline 334 & НТ03 & H5 & petraea & lucidus & CB, Mátra & Mátrafüred & 47.83 & 19.97 & GU386379 \\
\hline 345 & НТ03 & H5 & petraea & lignicolus & $\mathrm{CB}$, Mátra & Mátrafüred & 47.83 & 19.97 & GU386379 \\
\hline 357 & НТ03 & H5 & pubescens & kollari & CB, Mátra & Mátrafüred & 47.83 & 19.97 & GU386379 \\
\hline 359 & НТ03 & H5 & robur & lucidus & $\mathrm{CB}$, Mátra & Mátrafüred & 47.83 & 19.97 & GU386379 \\
\hline 584 & НТ03 & H5 & petraea & infectorius & CB, Mátra & Mátrafüred & 47.83 & 19.97 & GU386379 \\
\hline 593 & НТ03 & $\mathrm{H} 5$ & petraea & lucidus & CB, Mátra & Mátrafüred & 47.83 & 19.97 & GU386379 \\
\hline 725 & НТ03 & H5 & petraea & kollari & $\mathrm{CB}$, Mátra & Mátrafüred & 47.83 & 19.97 & GU386379 \\
\hline 483 & НТ03 & H5 & robur & lignicolus & CB, Mecsek & Pécsvárad & 46.17 & 18.4 & GU386379 \\
\hline 484 & НТ03 & H5 & robur & lignicolus & CB, Mecsek & Pécsvárad & 46.17 & 18.4 & GU386379 \\
\hline 671 & НТ03 & H5 & & panteli & $\mathrm{TL}$ & TURKEY, Beybesli & 41.05 & 35.88 & GU386379 \\
\hline 675 & НТ03 & H5 & & infectorius & $\mathrm{TL}$ & $\begin{array}{l}\text { TURKEY, Beybesli } \\
\text { TURKEY, Elev, Sivas-karacayir }\end{array}$ & 41.05 & 35.88 & GU386379 \\
\hline 711 & НT03 & H5 & & quercustozae & TL & area & 39.91 & 37.01 & GU386379 \\
\hline 656 & НТ03 & H5 & & lucidus & TL & TURKEY, Niksar & 40.59 & 36.95 & GU386379 \\
\hline 672 & НТ03 & H5 & & infectorius & TL & TURKEY, Niksar & 40.59 & 36.95 & GU386379 \\
\hline 665 & НТ03 & H5 & & lucidus & $\mathrm{TL}$ & TURKEY, Suluova & 40.82 & 35.63 & GU386379 \\
\hline 613 & НT03 & H5 & & coriarius & TL & $\begin{array}{l}\text { TURKEY, Tokat } \\
\text { CZECH REPUBLIC, Ceske }\end{array}$ & 40.31 & 36.54 & GU386379 \\
\hline 698 & HT04 & $\mathrm{H} 6$ & & quercuscalicis & $\mathrm{CB}$ & $\begin{array}{l}\text { Budejovice } \\
\text { CZECH REPUBLIC, Ceske }\end{array}$ & 48.97 & 14.47 & GU386380 \\
\hline 699 & HT04 & $\mathrm{H} 6$ & & quercuscalicis & $\mathrm{CB}$ & Budejovice & 48.97 & 14.47 & GU386380 \\
\hline 415 & HT04 & $\mathrm{H} 6$ & ?robur & kollari & $\mathrm{CB}$ & Gyula & 46.64 & 21.27 & GU386380 \\
\hline
\end{tabular}




\begin{tabular}{|c|c|c|c|c|c|c|c|c|c|}
\hline 455 & HT04 & $\mathrm{H} 6$ & & hungaricus & $\mathrm{CB}$ & Gyula & 46.64 & 21.27 & GU386380 \\
\hline 447 & HT04 & $\mathrm{H} 6$ & & quercuscalicis & CB, Aggtelek & Aggtelek & 48.47 & 20.5 & GU386380 \\
\hline 717 & HT04 & $\mathrm{H} 6$ & petraea & lignicolus & $\mathrm{CB}$, Aggtelek & Jósvafő & 48.48 & 20.55 & GU386380 \\
\hline 576 & НT04 & $\mathrm{H} 6$ & & quercustozae & CB, Aggtelek & Szőlősardó & 48.44 & 20.63 & GU386380 \\
\hline 577 & НT04 & $\mathrm{H} 6$ & & quercustozae & CB, Aggtelek & Szőlősardó & 48.44 & 20.63 & GU386380 \\
\hline 572 & НT04 & $\mathrm{H} 6$ & petraea & lignicolus & $\mathrm{CB}$, Eger & Eger & 47.9 & 20.37 & GU386380 \\
\hline 400 & НT04 & $\mathrm{H} 6$ & robur & quercuscalicis & CB, Gödöllő & Gödöllő & 47.6 & 19.35 & GU386380 \\
\hline 505 & HT04 & $\mathrm{H} 6$ & petraea & kollari & CB, Mátra & Mátra, Sás-tó & 47.843 & 19.96 & GU386380 \\
\hline 506 & HT04 & $\mathrm{H} 6$ & petraea & kollari & CB, Mátra & Mátra, Sás-tó & 47.843 & 19.96 & GU386380 \\
\hline 462 & HT04 & $\mathrm{H} 6$ & petraea & kollari & $\mathrm{CB}$, Mátra & Mátrafüred & 47.83 & 19.97 & GU386380 \\
\hline 662 & HT04 & $\mathrm{H} 6$ & robur & quercuscalicis & IT & CROATIA, Karlovac & 45.5 & 15.57 & GU386380 \\
\hline 647 & НT04 & $\mathrm{H} 6$ & & dentimitratus & IT & ITALY, Capalbio Campo Cane & 42.51 & 11.57 & GU386380 \\
\hline 681 & НT04 & $\mathrm{H} 6$ & & dentimitratus & IT & ITALY, Gargano & 41.76 & 15.83 & GU386380 \\
\hline 637 & HT04 & $\mathrm{H} 6$ & & quercustozae & IT & ITALY, Massa Maritima & 43.05 & 10.9 & GU386380 \\
\hline 642 & HT04 & $\mathrm{H} 6$ & & kollari & & France, Coutances & 49.05 & -1.45 & GU386380 \\
\hline 644 & НT04 & $\mathrm{H} 6$ & & kollari & & $\begin{array}{l}\text { France, Foret de Berce } \\
\text { France, Nogent-sur-Vernisson, }\end{array}$ & 47.78 & 0.38 & GU386380 \\
\hline 702 & HT04 & $\mathrm{H} 6$ & & quercuscalicis & & $\begin{array}{l}\text { arboretum } \\
\text { France, Nogent-sur-Vernisson, }\end{array}$ & 47.83 & 2.7 & GU386380 \\
\hline 713 & НT04 & $\mathrm{H} 6$ & & quercuscalicis & & arboretum & 47.83 & 2.7 & GU386380 \\
\hline 456 & HT05 & $\mathrm{H} 2$ & ?robur & infectorius & CB, Mecsek & Orfü & 46.14 & 18.15 & GU386381 \\
\hline 478 & HT05 & $\mathrm{H} 2$ & robur & ?infectorius & CB, Mecsek & Pécsvárad & 46.17 & 18.4 & GU386381 \\
\hline 650 & HT05 & $\mathrm{H} 2$ & & caputmedusae & IT & ITALY, Assergii & 42.42 & 13.5 & GU386381 \\
\hline 674 & HT05 & $\mathrm{H} 2$ & & dentimitratus & IT & ITALY, Castagnola & 44.41 & 9.99 & GU386381 \\
\hline 653 & HT05 & $\mathrm{H} 2$ & & panteli & IT & ITALY, Felitto (Cilento) & 40.37 & 15.24 & GU386381 \\
\hline 636 & HT05 & $\mathrm{H} 2$ & pubescens & quercustozae & IT & ITALY, Molio, & 40.09 & 15.77 & GU386381 \\
\hline 648 & НT05 & $\mathrm{H} 2$ & & lucidus & IT & ITALY, Monte St Angelo & 41.71 & 16 & GU386381 \\
\hline 679 & HT05 & $\mathrm{H} 2$ & & panteli & IT & ITALY, Monte St Angelo & 41.71 & 16 & GU386381 \\
\hline 678 & HT05 & $\mathrm{H} 2$ & & caputmedusae & IT & ITALY, Piedmont & 45.05 & 7.51 & GU386381 \\
\hline 437 & HT05 & $\mathrm{H} 2$ & & grossulariae & UK & UK, Ascott-under-wychwood & 51.86 & -1.57 & GU386381 \\
\hline 700 & HT05 & $\mathrm{H} 2$ & & quercuscalicis & UK & UK, Farnham Park & 51.55 & -0.61 & GU386381 \\
\hline 704 & HT05 & $\mathrm{H} 2$ & & grossulariae & UK & UK, Farnham Park & 51.55 & -0.61 & GU386381 \\
\hline 701 & HT05 & $\mathrm{H} 2$ & & quercuscalicis & UK & UK, Maidenhead Thicket & 51.52 & -0.77 & GU386381 \\
\hline 703 & HT05 & $\mathrm{H} 2$ & & grossulariae & UK & UK, Maidenhead Thicket & 51.52 & -0.77 & GU386381 \\
\hline 706 & HT05 & $\mathrm{H} 2$ & & grossulariae & UK & UK, Maidenhead Thicket & 51.52 & -0.77 & GU386381 \\
\hline 705 & HT05 & $\mathrm{H} 2$ & & quercuscalicis & UK & UK, Pinkneys Green & 51.53 & -0.76 & GU386381 \\
\hline 658 & HT05 & $\mathrm{H} 2$ & & coriarius & & Greece, Florina & 40.78 & 21.4 & GU386381 \\
\hline 614 & HT05 & $\mathrm{H} 2$ & & quercustozae & & Greece, Pisoderi & 40.79 & 21.28 & GU386381 \\
\hline
\end{tabular}




\begin{tabular}{|c|c|c|c|c|c|c|c|c|c|}
\hline 664 & HT05 & $\mathrm{H} 2$ & & coronatus & & Greece, Pisoderi & 40.79 & 21.28 & GU386381 \\
\hline 610 & HT06 & $\mathrm{H} 8$ & & insana & IR & IRAN, Golestan & 37.12 & 55 & GU386382 \\
\hline 634 & HT06 & $\mathrm{H} 8$ & & quercustozae & IR & $\begin{array}{l}\text { IRAN, Kermanshah, Gahvareh } \\
\text { IRAN, Kermanshah, Gahvareh, }\end{array}$ & 34.34 & 46.42 & GU386382 \\
\hline 709 & HT06 & $\mathrm{H} 8$ & & quercustozae & IR & Sar-pol-zahab & 34.46 & 45.48 & GU386382 \\
\hline 616 & HT06 & $\mathrm{H} 8$ & & quercustozae & IR & IRAN, Lorestan & 33.86 & 48.21 & GU386382 \\
\hline 607 & HT06 & $\mathrm{H} 8$ & & askewi & IR & IRAN, Piran Shahr & 36.73 & 45.19 & GU386382 \\
\hline 609 & НT06 & $\mathrm{H} 8$ & & askewi & IR & $\begin{array}{l}\text { IRAN, Piran Shahr } \\
\text { IRAN, Piran Shahr (West }\end{array}$ & 36.73 & 45.19 & GU386382 \\
\hline 621 & HT06 & $\mathrm{H} 8$ & & askewi & IR & $\begin{array}{l}\text { Azerbaijan) } \\
\text { IRAN, Sar Dasht, Rabat station }\end{array}$ & 36.73 & 45.19 & GU386382 \\
\hline 710 & HT06 & $\mathrm{H} 8$ & & lucidus & IR & (West Azerbaijan) & 36.15 & 45.48 & GU386382 \\
\hline 10067 & HT07 & $\mathrm{H} 2$ & robur & lignicolus & CB, Gödöllö & Gödöllő & 47.6 & 19.35 & GU386383 \\
\hline 416 & НT07 & $\mathrm{H} 2$ & ?robur & $\begin{array}{l}\text { hungaricus } \\
\text { Cynips }\end{array}$ & CB, Mecsek & Orfü & 46.14 & 18.15 & GU386383 \\
\hline 680 & HT07 & $\mathrm{H} 2$ & & quercus & IT & ITALY, Cilento & 40.24 & 15.34 & GU386383 \\
\hline 635 & НT07 & $\mathrm{H} 2$ & & quercustozae & IT & ITALY, Gildone & 41.51 & 14.75 & GU386383 \\
\hline 618 & НT08 & $\mathrm{H} 7$ & faginea & quercustozae & IM & PORTUGAL, Cabeca Gorda & 39.19 & -9.26 & GU386384 \\
\hline 620 & НT08 & $\mathrm{H} 7$ & faginea & quercustozae & IM & PORTUGAL, Paredes & 41.2 & -8.33 & GU386384 \\
\hline 619 & НТ08 & $\mathrm{H} 7$ & faginea & quercustozae & IM & PORTUGAL, Sobreiro de Cima & 41.84 & -7.06 & GU386384 \\
\hline 602 & НT08 & $\mathrm{H} 7$ & & grossulariae & $\mathrm{IM}$ & SPAIN, Sta Fe de Mondújar & 36.97 & -2.53 & GU386384 \\
\hline 707 & НТ09 & $\mathrm{H} 6$ & & kollari & UK & UK, Bovey Tracey & 50.58 & -3.68 & GU386385 \\
\hline 708 & НT09 & $\mathrm{H} 6$ & & kollari & UK & UK, Faggs Wood & 51.075 & 0.83 & GU386385 \\
\hline 641 & HT09 & $\mathrm{H} 6$ & & kollari & & France, St. Malo & 48.65 & -2.02 & GU386385 \\
\hline 361 & HT10 & $\mathrm{H} 4$ & petraea & infectorius & $\mathrm{CB}$, Mátra & Mátrafüred & 47.83 & 19.97 & GU386386 \\
\hline 371 & HT10 & $\mathrm{H} 4$ & petraea & conglomeratus & CB, Mátra & Mátrafüred & 47.83 & 19.97 & GU386386 \\
\hline 464 & HT10 & $\mathrm{H} 4$ & petraea & conglomeratus & $\mathrm{CB}$, Mátra & Mátrafüred & 47.83 & 19.97 & GU386386 \\
\hline 547 & HT11 & H5 & petraea & lignicolus & $\mathrm{CB}$, Aggtelek & Jósvafő & 48.48 & 20.55 & GU386387 \\
\hline 519 & HT11 & H5 & petraea & lignicolus & $\mathrm{CB}$, Eger & Eger & 47.9 & 20.37 & GU386387 \\
\hline 496 & HT11 & H5 & petraea & glutinosus & CB, Mátra & Mátra, Sás-tó & 47.843 & 19.96 & GU386387 \\
\hline 504 & HT12 & H5 & petraea & ?infectorius & CB, Mátra & Mátra, Sás-tó & 47.843 & 19.96 & GU386388 \\
\hline 509 & HT12 & H5 & petraea & lignicolus & $\mathrm{CB}$, Mátra & Mátra, Sás-tó & 47.843 & 19.96 & GU386388 \\
\hline 21775 & HT12 & H5 & petraea & lucidus & CB, Mátra & Mátrafüred & 47.83 & 19.97 & GU386388 \\
\hline 673 & HT13 & $\mathrm{H} 3$ & & infectorius & $\mathrm{CB}$ & SLOVAKIA, Sikenicka & 47.93 & 18.68 & GU386389 \\
\hline 639 & HT13 & H3 & & quercustozae & IT & CROATIA, Istria & 45.31 & 14.01 & GU386389 \\
\hline 640 & HT13 & H3 & & quercustozae & IT & CROATIA, Istria & 45.31 & 14.01 & GU386389 \\
\hline 569 & HT14 & $\mathrm{H} 1$ & petraea & kollari & $\mathrm{CB}$, Eger & Eger & 47.9 & 20.37 & GU386390 \\
\hline 724 & HT14 & $\mathrm{H} 1$ & petraea & kollari & $\mathrm{CB}$, Eger & Eger & 47.9 & 20.37 & GU386390 \\
\hline 652 & HT14 & $\mathrm{H} 1$ & & seckendorffi & IT & ITALY, Monte Vulture & 40.95 & 15.63 & GU386390 \\
\hline
\end{tabular}




\begin{tabular}{|c|c|c|c|c|c|c|c|c|c|}
\hline 331 & HT15 & $\mathrm{H} 1$ & petraea & lignicolus & CB, Mátra & Mátrafüred & 47.83 & 19.97 & GU386391 \\
\hline 541 & HT15 & $\mathrm{H} 1$ & robur & lignicolus & CB, Mecsek & Orfü & 46.14 & 18.15 & GU386391 \\
\hline 362 & HT16 & $\mathrm{H} 3$ & robur & hungaricus & CB, Gödöllő & Gödöllő & 47.6 & 19.35 & GU386392 \\
\hline 382 & HT16 & $\mathrm{H} 3$ & robur & infectorius & CB, Gödöllő & Gödöllő & 47.6 & 19.35 & GU386392 \\
\hline 570 & HT17 & $\mathrm{H} 1$ & petraea & lignicolus & CB, Eger & Eger & 47.9 & 20.37 & GU386393 \\
\hline 561 & HT17 & $\mathrm{H} 1$ & robur & lignicolus & CB, Mecsek & Pécsvárad & 46.17 & 18.4 & GU386393 \\
\hline 586 & HT18 & $\mathrm{H} 1$ & petraea & kollari & CB, Mátra & Mátrafüred & 47.83 & 19.97 & GU386394 \\
\hline 579 & HT18 & $\mathrm{H} 1$ & pubescens & ?polycerus & CB, Mecsek & Pécsvárad & 46.17 & 18.4 & GU386394 \\
\hline 348 & HT19 & $\mathrm{H} 6$ & petraea & infectorius & CB, Mátra & Mátrafüred & 47.83 & 19.97 & GU386395 \\
\hline 587 & HT19 & $\mathrm{H} 6$ & petraea & kollari & CB, Mátra & Mátrafüred & 47.83 & 19.97 & GU386395 \\
\hline 686 & HT20 & $\mathrm{H} 7$ & & panteli & $\mathrm{IM}$ & MOROCCO, Azrou & 30.36 & -9.46 & GU386396 \\
\hline 687 & HT20 & $\mathrm{H} 7$ & & panteli & IM & $\begin{array}{l}\text { MOROCCO, Azrou } \\
\text { IRAN, Piran Shahr (West }\end{array}$ & 30.36 & -9.46 & GU386396 \\
\hline 623 & HT21 & $\mathrm{H} 2$ & & megalucidus & IR & Azerbaijan) & 36.73 & 45.19 & GU386397 \\
\hline 624 & HT21 & $\mathrm{H} 2$ & & theophrastae & TL & TURKEY, Beysehir & 37.67 & 31.72 & GU386397 \\
\hline 631 & НT22 & $\mathrm{H} 8$ & & askewi & IR & $\begin{array}{l}\text { IRAN, Kordestan, Marivan } \\
\text { IRAN, Piran Shahr (West }\end{array}$ & 35.52 & 46.17 & GU386398 \\
\hline 622 & HT22 & $\mathrm{H} 8$ & & lucidus & IR & $\begin{array}{l}\text { Azerbaijan) } \\
\text { LEBANON, Ras el maten, }\end{array}$ & 36.73 & 45.19 & GU386398 \\
\hline 682 & HT23 & H5 & & & TL & Lamartine valley & 33.86 & 35.62 & GU386399 \\
\hline 617 & HT23 & H5 & infectoria & quercustozae & TL & TURKEY, Yeniyol & 39.9 & 39.4 & GU386399 \\
\hline 712 & HT24 & $\mathrm{H} 6$ & & quercuscalicis & & Germany, Ludwigsburg & 48.9 & 9.19 & GU386400 \\
\hline 660 & HT25 & $\mathrm{H} 2$ & & corruptrix & & Greece, Arnissa & 40.8 & 21.83 & GU386401 \\
\hline 333 & НT26 & $\mathrm{H} 1$ & robur & lucidus & CB, Mátra & Mátrafüred & 47.83 & 19.97 & GU386402 \\
\hline 358 & HT27 & $\mathrm{H} 1$ & petraea & lignicolus & $\mathrm{CB}$, Mátra & Mátrafüred & 47.83 & 19.97 & GU386403 \\
\hline 372 & HT28 & $\mathrm{H} 1$ & pubescens & conficus & CB, Mátra & Mátrafüred & 47.83 & 19.97 & GU386404 \\
\hline 411 & HT29 & $\mathrm{H} 1$ & ?robur & lucidus & CB & Borsod & 48.3 & 20.7 & GU386405 \\
\hline 454 & НT30 & $\mathrm{H} 1$ & & kollari & $\mathrm{CB}$ & Debrecen & 47.58 & 21.63 & GU386406 \\
\hline 471 & НT31 & $\mathrm{H} 1$ & petraea & coriarius & CB, Mátra & Mátra, Sár-hegy & 47.8 & 19.97 & GU386407 \\
\hline 476 & HT32 & $\mathrm{H} 5$ & pubescens & ?infectorius & CB, Mecsek & Pécsvárad & 46.17 & 18.4 & GU386408 \\
\hline 491 & НТз3 & $\mathrm{H} 1$ & pubescens & lucidus & CB, Mecsek & Pécsvárad & 46.17 & 18.4 & GU386409 \\
\hline 499 & НТ34 & $\mathrm{H} 1$ & petraea & glutinosus & CB, Mátra & Mátra, Sás-tó & 47.843 & 19.96 & GU386410 \\
\hline 510 & HT35 & H5 & petraea & lignicolus & $\mathrm{CB}$, Mátra & Mátra, Sás-tó & 47.843 & 19.96 & GU386411 \\
\hline 513 & HT36 & $\mathrm{H} 5$ & petraea & lucidus & CB, Mátra & Mátra, Sás-tó & 47.843 & 19.96 & GU386412 \\
\hline 517 & НT37 & $\mathrm{H} 1$ & petraea & lignicolus & CB, Eger & Eger & 47.9 & 20.37 & GU386413 \\
\hline 518 & НТ38 & $\mathrm{H} 1$ & petraea & lignicolus & CB, Eger & Eger & 47.9 & 20.37 & GU386414 \\
\hline 526 & НТ39 & $\mathrm{H} 1$ & petraea & lignicolus & $\mathrm{CB}$, Mátra & Mátra, Sár-hegy & 47.8 & 19.97 & GU386415 \\
\hline 531 & HT40 & H5 & petraea & lignicolus & CB, Aggtelek & Szőlösardó & 48.44 & 20.63 & GU386416 \\
\hline
\end{tabular}




\begin{tabular}{|c|c|c|c|c|c|c|c|c|c|}
\hline 543 & HT41 & $\mathrm{H} 2$ & robur & lignicolus & CB, Mecsek & Orfü & 46.14 & 18.15 & GU386417 \\
\hline 546 & HT42 & $\mathrm{H} 1$ & petraea & lignicolus & $\mathrm{CB}$, Aggtelek & Jósvafö & 48.48 & 20.55 & GU386418 \\
\hline 557 & HT43 & $\mathrm{H} 1$ & pubescens & lucidus & CB, Aggtelek & Jósvafő & 48.48 & 20.55 & GU386419 \\
\hline 559 & HT44 & $\mathrm{H} 1$ & pubescens & lucidus & $\mathrm{CB}$, Aggtelek & Jósvafö & 48.48 & 20.55 & GU386420 \\
\hline 573 & HT45 & H5 & petraea & lignicolus & CB, Eger & Eger & 47.9 & 20.37 & GU386421 \\
\hline 578 & HT46 & H5 & robur & sternlichti? & $\mathrm{CB}$, Mecsek & Pécsvárad & 46.17 & 18.4 & GU386422 \\
\hline 588 & HT47 & $\mathrm{H} 1$ & petraea & kollari & CB, Mátra & Mátrafüred & 47.83 & 19.97 & GU386423 \\
\hline 6161 & HT48 & $\mathrm{H} 2$ & ?robur & coriarius & CB, Gödöllő & Gödöllő & 47.6 & 19.35 & GU386424 \\
\hline 718 & HT49 & $\mathrm{H} 2$ & petraea & lignicolus & CB, Mátra & Mátra, Sás-tó & 47.843 & 19.96 & GU386425 \\
\hline 615 & HT50 & H3 & & quercustozae & IM & MOROCCO, Azrou & 30.36 & -9.46 & GU386426 \\
\hline 677 & HT51 & $\mathrm{H} 3$ & & kollari & IM & SPAIN, Montseny (Barcelona) & 41.76 & 2.39 & GU386427 \\
\hline 685 & HT52 & $\mathrm{H} 7$ & & panteli & IM & MOROCCO, Azrou & 30.36 & -9.46 & GU386428 \\
\hline 608 & HT53 & $\mathrm{H} 8$ & & askewi & IR & IRAN, Piran Shahr & 36.73 & 45.19 & GU386429 \\
\hline 627 & HT54 & $\mathrm{H} 8$ & & curtisii & IR & IRAN, Lorestan, Ghelaie & 33.86 & 48.21 & GU386430 \\
\hline 628 & HT55 & $\mathrm{H} 8$ & & curtisii & IR & IRAN, Kordestan, Marivan & 35.52 & 46.17 & GU386431 \\
\hline 629 & HT56 & $\mathrm{H} 8$ & & lucidus & $\mathrm{IR}$ & IRAN, Kermanshah, Sar Pol Zahab & 34.46 & 45.48 & GU386432 \\
\hline 630 & HT57 & $\mathrm{H} 8$ & & sternlichti & IR & IRAN, Lorestan, Ghelaie & 33.86 & 48.21 & GU386433 \\
\hline 632 & HT58 & $\mathrm{H} 8$ & & lucidus & IR & IRAN, Kordestan, Marivan & 35.52 & 46.17 & GU386434 \\
\hline 633 & HT59 & $\mathrm{H} 8$ & & sternlichti & $\mathrm{IR}$ & IRAN, Lorestan, Ghelaie & 33.86 & 48.21 & GU386435 \\
\hline 651 & HT60 & $\mathrm{H} 2$ & & coronatus & IT & ITALY, Piombino & 42.92 & 10.52 & GU386436 \\
\hline 676 & HT61 & $\mathrm{H} 2$ & & coriarius & IT & ITALY, Moio della Civitella & 40.24 & 15.27 & GU386437 \\
\hline 655 & HT62 & H5 & & coriarius & TL & TURKEY, Suluova & 40.82 & 35.63 & GU386438 \\
\hline 657 & HT63 & H5 & & coriarius & TL & TURKEY, Beybesli & 41.05 & 35.88 & GU386439 \\
\hline 667 & HT64 & $\mathrm{H} 8$ & & seckendorffi & TL & TURKEY, Külüce & 39.27 & 34.83 & GU386440 \\
\hline 436 & HT65 & $\mathrm{H} 2$ & & grossulariae & UK & UK, Ascott-under-wychwood & 51.86 & -1.57 & GU386441 \\
\hline 626 & HT66 & $\mathrm{H} 2$ & & lucidus & UK & UK, Ascott-under-wychwood & 51.86 & -1.57 & GU386442 \\
\hline
\end{tabular}


2. függelék A Synergus umbraculus citokróm b haplotípusokra számolt 95\% megbízhatósági szintủ hálózat, melyet a Splitstree szoftverrel készítettünk. NeighbourNet módszert és equal angle split transzormációt használtunk, 200 bootstrap ismétléssel. Az ábrán csak a haplocsoport neveket tüntettük fel.

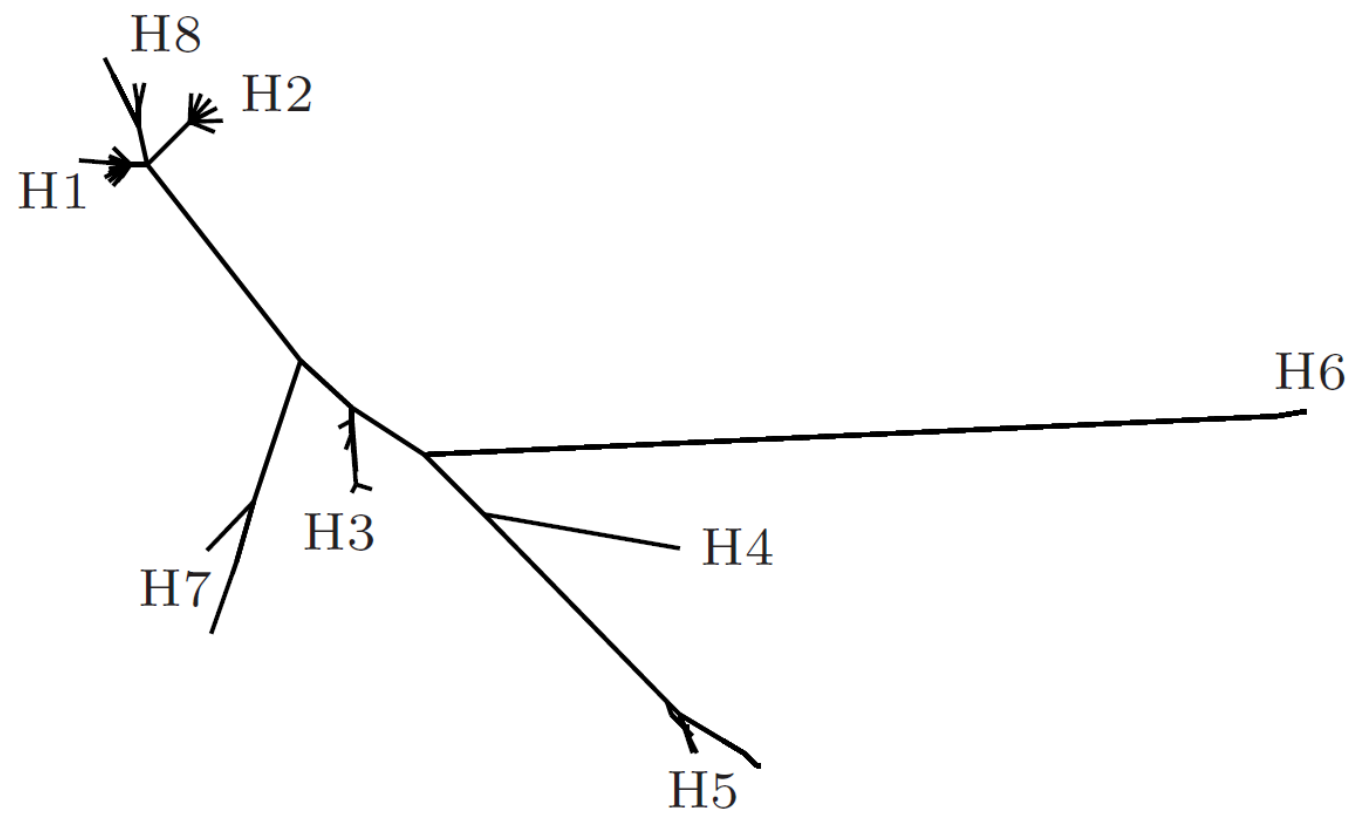

